\title{
A NeWly Discovered Treatise by Abraham IbN EZRA AND TWO TREATISES ATTRIBUTED TO AL-KINDİ IN A LATIN TRANSLATION BY HENRY BATE*
}

\author{
Shlomo Sela (BAR ILAN UNIVERSITY) \\ CARLOS STEEL (UNIVERSITY OF LEUVEN) \\ C. Philipp E. Nothaft (All Souls College, Oxford)

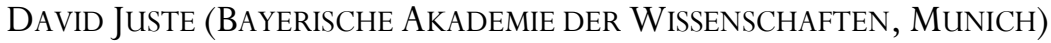 \\ Charles BurnetT (The Warburg InStitute)
}

\begin{abstract}
The main objective of the current study is to offer the first critical edition, accompanied by an English translation and introductory study, of a tripartite Latin text addressing world astrology preserved in a single manuscript: MS Vatican City, Biblioteca Apostolica Vaticana, Pal. lat. 1407, fols. 55r-62r (14 $4^{\text {th }} / 15^{\text {th }}$ century). This study also includes the Middle English translation of discontinuous sections of this tripartite Latin text as transmitted in MS London, Royal College of Physicians, 384, fols. 83v-85r. It is argued that the first part of this tripartite text incorporates a hitherto unknown Latin translation by Henry Bate of the lost third version of Abraham Ibn Ezra's Sefer ha-'Olam. The other two parts include two Latin translations, also carried out by Henry Bate, of treatises ascribed to Ya'qūb ibn Ishāq alKindī, the « philosopher of the Arabs ».
\end{abstract}

\section{Key Words}

120 conjunctions; Abū Ma'shar; Enoch (Hermes); Iohannes Hispalensis; Kanakah, the Indian; length of the solar year; lunar mansions; Māshäallāh; monotheistic religions; Sahl ibn Bishr, the Jew; Saturn-Jupiter conjunctions; Tables of Pisa; Tables of Winchester; weather forecasting.

* We are grateful to Julio Samsó for his comments on a first version of this article.

Mediterranea. International journal on the transfer of knowledge, 5 (2020), p. 193-305 ISSN: 2445-2378 
Shlomo Sela, Carlos Steel, C. Philipp E. Nothaft, David Juste \& Charles Burnett

\section{INTRODUCTION}

Henry Bate of Mechelen (1246-d. after 1310) is a key figure in the reception of Hebrew, Arabic, and Greek texts in the Latin West at the end of the thirteenth century. Bate was also the first to bring the astrological work of the twelfthcentury Jewish polymath Abraham Ibn Ezra (c. 1089-c. 1161) to the knowledge of Latin readers by means of an extensive translational project. ${ }^{1}$ The main objective of the current study is to offer the first critical edition, accompanied by an English translation and introductory study, of a tripartite Latin text addressing world astrology preserved in a single manuscript: MS Vatican City, Biblioteca Apostolica Vaticana, Pal. lat. 1407, fols. $55 \mathrm{r}-62 \mathrm{r}\left(14^{\text {th }} / 15^{\text {th }}\right.$ century). David Juste was the first to identify the source in question and report on the links between it and Henry Bate and Abraham Ibn Ezra. ${ }^{2}$ Building on Juste's discovery, this study argues that the first part of this tripartite text (henceforth Part I) incorporates a hitherto unknown Latin translation by Henry Bate of the lost third version of Abraham Ibn Ezra's Sefer ha-'Olam (henceforth 'Olam III). The other two parts (henceforth Part II and Part III) include two Latin translations, also carried out by Henry Bate, of treatises ascribed to Ya'qūb ibn Ishāq al-Kindī, the " philosopher of the Arabs » (d. after 866).

The critical edition of the Latin text, as well as an introduction to this edition, were prepared by Carlos Steel. The corresponding English translation was carried out by Shlomo Sela with the assistance of all the other authors of this study. This study also includes the Middle English translation of discontinuous sections of this tripartite Latin text as transmitted in MS London, Royal College of Physicians, 384, fols. 83v-85r. The edition of the Middle English translation and introduction to this edition were prepared by C. Philipp E. Nothaft.

In the first part of the ensuing introductory study, Shlomo Sela discusses the connection between Part I and Abraham Ibn Ezra's oeuvre and shows that Part I incorporates a hitherto unknown Latin translation of Ibn Ezra's 'Olam III. This is followed by Philipp Nothaft's analyses of the astronomical content of two chapters of Part I. Then David Juste examines the three horoscopes at the end of Part I. Next Shlomo Sela shows that Henry Bate was the translator of the tripartite Latin text and attempts to identify the translator of the Arabic into Hebrew translations involved in our tripartite text. Then Charles Burnett compares the doctrine of alKindī in Part II and Part III with the doctrine found in his other texts on weather forecasting and other aspects of general astrology and discusses whether the texts presented here may be considered as authentic Kindian treatises. Finally, David

1 Sнцомо SeLA, «The Ibn Ezra-Henry Bate Astrological Connection and the Three Abrahams », Mediterranea, 2 (2017), p. 163-186.

2 Carlos Steel, Steven Vanden Broecke, David Juste, Shlomo Sela, The Astrological Autobiography of a Medieval Philosopher: Henry Bate's 'Nativitas' (1280-1281), Leuven University Press, Leuven 2018 (Ancient and Medieval Philosophy. Series 1, 17), p. 49-50. 
Juste describes the two manuscripts in which are preserved the Latin and Middle English translations of Ibn Ezra's 'Olam III and the two Kindian treatises.

\section{I.1. A Hitherto Unknown Latin Translation of Abraham Ibn Ezra's 'Olam III $\left(\right.$ Shlomo Sela) ${ }^{3}$}

The first part of the tripartite text in MS Vatican City, Biblioteca Apostolica Vaticana, Pal. lat 1407 (fols. 55r-58r, henceforth Part I) ${ }^{4}$ covers almost half of the tripartite text (4,000 out of 8,400 words) and addresses a miscellany of topics related to world astrology, as will be shown below. Part I is not equipped with an incipit or a colophon from which we may determine whether this miscellany of discussions constitutes a translation of a Hebrew or Arabic original text, a compilation of fragments taken from a variety of sources, or an original Latin text addressing world astrology. Nevertheless, in what follows it will be shown that the contents of Part I are intimately related to Abraham Ibn Ezra's work. The following discussion is divided into two parts. The first shows that there are striking resemblances between the bulk of Part I and various parts of Abraham Ibn Ezra's work, as if Part I were the Latin translation of some unknown treatise by Ibn Ezra. The second part argues that Part I is a hitherto unknown Latin translation carried out by Henry Bate of the lost third version of Abraham Ibn Ezra's Sefer ha-'Olam (henceforth 'Olam III).

\section{I.1.1.}

According to its content, Part I may be divided into seven chapters addressing topics related to world astrology. The following discussion shows that, although there are no verbatim quotations from Ibn Ezra's work in Part I, each of its chapters evinces striking resemblances with Ibn Ezra's work. This strongly suggests that Part I is the Latin translation of some unknown version of Ibn Ezra's Sefer ha-'Olam, which address world astrology. That there are no verbatim quotations from other treatises by Ibn Ezra is typical of Ibn Ezra's modus operandi. He writes his books in various versions but never quotes verbatim from one version into another of the same book, although he incorporates ideas developed in one book into another.

1. The first chapter of Part I, a preface mentioning the hierarchical relationship between the superlunary and sublunary bodies, speaking about emanation by means of light, and highlighting the power of the superlunaries as a function of

3 Sections I and V of this introduction were supported by the Israel Science Foundation (grant No. 289/17).

4 See below Part I, §1.1:1-9 through §7.1:1-21. Here Part I, §7.1:1-21 stands for First part of the tripartite text, seventh section ("On the great conjunction»), first paragraph, sentences 1 through 21, of the Latin text and its corresponding English translation. 
Shlomo Sela, Carlos Steel, C. Philipp E. Nothaft, David Juste \& Charles Burnett

their size and their relative closeness to the Earth, is similar to the preface of Ibn Ezra's Sefer ha-Me'orot. ${ }^{5}$ Ibn Ezra does not mention in his astrological treatises " souls of living things that are like forms coming from the movers of the orbs and from the light of the fixed and wandering stars ", but he does so in his biblical commentaries. ${ }^{6}$ The statement that the human soul is connected to the superlunary world finds its counterpart in one of the versions of Ibn Ezra's Sefer ha-She elot. ${ }^{7}$ The brief account of the structure of the superlunary world is couched in similar terms to those used in the prefaces of Reshit Hokhmah, and Mishpetei haMazzalot. ${ }^{8}$

2. The second chapter of Part I, on the nature of planets and the zodiacal signs, is a close counterpart of a similar discussion in the first version of Ibn Ezra's Sefer ha-Te'amim, which, in its turn, is based on a similar account in Abū Ma shar's Great Introduction. ${ }^{9}$ In particular, Ibn Ezra's distinctive hallmark in this chapter of Part I is found in the claim that the judgments of the stars are derived from their proportions, and in the ascription of numbers to the planets. ${ }^{10}$ These numbers depend on the theory, of Pythagorean origin, that each of the seven planets has numbers that correspond to the musical tones produced by the rotation of their orbs. Ibn Ezra explicitly ascribes this theory to Ptolemy in both versions of Sefer ha-Te amim, where he assigns a number to each of the seven planets. ${ }^{11}$ Virtually the same numbers ascribed to the planets in Téamim I, Te'amim II and in the second chapter of Part I are found in the Canobic Inscription, an early work by Ptolemy, predating the Almagest. ${ }^{12}$ But Ibn Ezra probably derived the information on this theory from the Epistle on Music of the Ikhwān al-Ṣafāà, which incorporates a full account of the theory. ${ }^{13}$

\footnotetext{
See Part I, §1.1:1-4; Cf. Me’orot, ed. SELA, §1:1-3, p. 452-453.

See Part I, §1.1:2; cf. Ibn Ezra's long comm. on Gen. 1:1, and long comm. on Ex. 3:15.

See Part I, §1.1:5; cf. She elot I, ed. SELA, I, §2:1-3, §1:3-7, p. 240-241.

See Part I, §1.1:6-9; cf. Reshit Hokhmah, ed. SeLA, §1.2:1-2 through §1.7:1-3, p. 50-55; Mishpetei haMazzalot, ed. SELA, \$1:1-2, p. 488-489.

9 See Part I, §2.1:1-3 through \$2.6:1-4; cf. Téamim I, ed. SELA, \$1.5:1-7, p. 32-37, and ABŪ MA'sHAR, The Great Introduction to Astrology, ed. and trans. KeIjI Yamamoto, Charles BurnetT, Brill, Leiden 2019 (Islamic Philosophy, Theology and Science, 106), vol. I, IV 1.4-1.10, p. 347-377.

10 See Part I, §4.1:1-4.

11 See Téamim I, ed. SeLA, §4.1:1-3, p. 68-71 and Téamim II, ed. SELA, §5.5:6, p. 230-231. I am not aware of other astrological texts that applied this theory to explain the natures of the planets.

12 See Noel M. Swerdlow, "Ptolemy's Harmonics and the 'Tones of the Universe' in the Canobic Inscription», in Charles Burnett, Jan P. Hogendij, Kim PlofKer, Michio Yano (eds.), Studies in the History of the Exact Sciences in Honour of David Pingree, Brill, Leiden - Boston, 2004 (Islamic Philosophy, Theology, and Science: Texts and Studies, 54), p. 137-180.

13 Epistle on Music of the Ikhwān al-Ṣafā', ed. Amnon SHILOAH, Tel Aviv University, Tel Aviv 1978, p. 38,
} $45-46$. 
In addition, a statement ascribed in Part I to al-Kindī regarding the nature of the beginning of the revolutions of the four seasons, corresponds closely to similar statements ascribed to al-Kindī in Țéamim I and Țéamim II. ${ }^{14}$

3. The third chapter of Part I, on planetary conjunctions, has a close counterpart in 'Olam I and 'Olam II. ${ }^{15}$ Here Ibn Ezra's signature is particularly manifest in that, just before the presentation of the three types of Saturn-Jupiter conjunctions, Part I puts forward the numerical-cosmological pattern of the 120 conjunctions of the seven planets (that is, the sum of the combinations of two, three, four, five, six, and seven planets) borrowed from the fiftieth aphorism of Pseudo-Ptolemy's Centiloquium and frequently mentioned in Ibn Ezra's biblical exegesis and astrological work. ${ }^{16}$ Put in other words: we can find the accounts of the pattern of the 120 conjunctions of the seven planets and of the three types of Saturn-Jupiter conjunctions together, the one immediately after the other, only in Part I and in works authored by Ibn Ezra or closely associated to Ibn Ezra, such as the first part, on world astrology, of the Epitome totius astrologiae (henceforth Epitome). ${ }^{17}$

A further distinctive feature is the reference en bloc to the zodiacal signs in charge of, or the reference to the Saturn-Jupiter conjunctions that heralded, the emergence of the three monotheistic religions, and in particular to the reference to Aquarius as the sign in charge of the Jews, or to a Saturn-Jupiter conjunction in Aquarius that heralded the Jews' exodus from Egypt. As in the previous example, such a statement can only be found in Part I and in works authored by Ibn Ezra or closely associated to Ibn Ezra, such as the Liber Abraham Iudei de nativitatibus. ${ }^{18}$

4. The brief fourth chapter of Part I, on the judgments of the world-years, enjoins the reader not to rely on the cycles of 2000 years according to the degrees of the zodiac. ${ }^{19}$ This is a veritable rarity: I could not find such a cycle in astrological literature except for the first paragraph of Liber Interrogationum (henceforth Interrogationes), the Latin translation of the lost third version of Ibn Ezra's Sefer ha-

14 See Part I, §2.3:1-3; cf. Țe amim I, ed. SELA, §1.4:2-3, p. 32-33 and Țe amim II, ed. SELA, §2.1:6-10, p. 184-187.

15 See Part I §3.1:1 through §3.4:1-3; cf. 'Olam I, ed. SELA, §2:1-3, p. 52-53 through §11:1-5, p. 58-59 and 'Olam II, ed. SELA, §1:1-3, p. 156-159.

16 See Shlomo Sela, Abraham Ibn Ezra Latinus on Nativities: A Parallel Latin-English Critical Edition of 'Liber Nativitatum' and 'Liber Abraham Iudei de Nativitatibus', Brill, Leiden 2019 (Études sur le judaïsme médiéval, 78), p. 175-177.

17 See Part I §3.1:1 and §3.2:1-7; 'Olam I, ed. SELA, §2:1-3, p. 52-53 through §10:1-2, p. 56-57; 'Olam II, ed. SeLA, \$2:1, p. 156-157 and §3:1-4, p. 156-157; Nativitates, ed. SeLA, I iv 1:1-8, p. 84-87 and I iv 2:1-3, p. 86-87; Ibn Ezra's long comm. on Ex. 33:21, quoted in The Book of the World, ed. SELA, \$2:14, p. 272-273 and \$3:1-4, p. 274-275; Epitome totius astrologiae, ed. JoACHIM HELLER, Johannes Montanus \& Ulrich Neuber, Nuremberg 1548, I:2, sig. F1v-F2r.

18 See Part I, §3.4:1; 'Olam II, ed. Sela, §14:1-6, p. 64-165; Nativitates, ed. SELA, I ii 2:1-2, p. 82-83; and De nativitatibus, ed. SELA, II ix 5:1-3, p. 334-335.

19 See Part I, §4.1:2-3. 
Shlomo Sela, Carlos Steel, C. Philipp E. Nothaft, David Juste \& Charles Burnett

She elot. ${ }^{20}$ The same fourth chapter puts forward cycles of 100 and 10 years, the counterpart of which may be found in the tenth chapter of Ibn Ezra's Reshit Hokhmah. ${ }^{21}$

5. The fifth chapter of Part I puts forward two complete lists of the 28 lunar mansions. The first is devoid of astrological content and provides, for each mansion, the Arabic transliterated name and its translation, the number of stars and their magnitude, and a graphic representation of the asterism. This list is a close replica of, although not identical with, the list of lunar mansions found in chapter 17 of Abraham Bar Hiyya's Hešbon mahalakhot ha-kokhavim ('Calculation of the stellar motions'). ${ }^{22}$ A clear indication that the Hebrew source text from which this list was translated was not authored by Abraham Bar Hiyya but by Abraham Ibn Ezra is that the concept of « magnitude of a star » is frequently denoted in Part I as honor, a calque of kavod, used by Ibn Ezra in all his star lists to denote the magnitude of a star but never employed with this meaning by Abraham Bar Hiiyya. $^{23}$

The second list presents, for each mansion, the zodiacal constellation, the Arabic name and its translation, the degrees, minutes and seconds that the mansion contains, and a note specifying whether the mansion is temperate, dry, humid or temperately humid. ${ }^{24}$ The Latin translations of some of the Arabic names of the lunar mansions in the second list are incompatible with the usual interpretations of the Arabic names. For example, the Arabic name of the $20^{\text {th }}$ lunar mansion, al-na $a^{\prime}{ }^{\prime} i m$, usually taken to denote ostriches, ${ }^{25}$ is interpreted in our Latin text as «delicie ». But this Arabic name is homophonous with the Hebrew na'im, meaning " pleasant » or « delicious ». So, the Latin translator, or, more precisely, the intermediary Hebrew into French translator, was probably reading the Arabic names in Hebrew script, and this seems to be the reason for the misinterpretations of the Arabic names. The $20^{\text {th }}$ lunar mansion includes a note specifying that this is " according to <John> of Seville and the seasons of the Indians». This is in all likelihood a cross-reference, probably added by the translator, to the list of lunar mansions in the first part of the Epitome. ${ }^{26}$ Indeed, the list in Epitome specifies first the datum whether the mansion is temperate, dry, humid or temperately humid,

\footnotetext{
See Interrogationes, ed. SELA, I 1:3.

See Part I, §4.1:3; cf. Reshit Hokhmah, ed. SELA, §10.2:6-9, p. 268-269.

2 See Part I, §5.2:1-28; cf. SHLomo SelA, « Chapter 17 of Hešbon Mahalakhot ha-Kokhavim by Abraham Bar Hiyya - The First Hebrew Catalog of Constellations, Fixed Stars and Lunar Mansions: Critical Edition, English Translation and Commentary », Suhayl, 15 (2017), p. 263-266, 271-272.

23 See, below, fn. 42 .

24 Part I, §5.3:1-28.

25 See "On the lunar stations, their risings and settings, and on their images ", in AL-BīrūNī, The Chronology of Ancient Nations, trans. and ed. C. EDWARD SACHAU, London 1879, (Oriental Translation Fund of Great Britain \& Ireland), chapter 21, p. 348.

26 See Part I, §5.3:20; Epitome, ed. JoAchim Heller (1548), I:11, sig. H1v-H2v.
} 
but could not have been possibly the source text of the second list in Part I because the mansions are named there in Latin and are accompanied by the number of stars, their magnitude, and a graphical representation of the asterism.

At the end of the second list, Part I brings a note, presumably interpolated by the translator, stating that «there are six mansions that are principally humid, according to the evidence provided by al-Kindī, and Ibn Ezra enumerates only those as humid, and they have been indicated here ». In this note, (i) the reference to al-Kindī labelling six lunar mansions as « humid » points to al-Kindī's Book on the judgments of the revolutions, in Part III of our text, ${ }^{27}$ and (ii) the reference to Ibn Ezra labelling the same lunar mansions as « humid » although other lunar mansions are moderately humid, and stating that these lunar mansions have been shown " here », points to the second list of lunar mansions in the fifth chapter of Part I. ${ }^{28}$ This note demonstrates without a shadow of doubt that the translator knew that the Hebrew original of the second list of lunar mansions, and presumably that of all of Part I, were composed by Abraham Ibn Ezra. In addition, this note creates a link between Part I and Part III of our tripartite text, from the perspective of the translator.

6. The sixth chapter of Part I, on the solar year, has a close counterpart in many parts of Ibn Ezra's oeuvre. In particular, the debate about the length of the solar year in Part I bears striking resemblances with discussions of the same topic in 'Olam I, Moladot, Te'amim I, Sefer ha-'Ibbur, 'Iggeret ha-Shabbat, the commentary on Leviticus 25:9, and Liber de rationibus tabularum..$^{29}$ The same applies to the discussion of the theory of trepidatio (i.e., a to-and-fro motion of the equinoxes or the fixed stars) in Part I, on the one hand, and in Te'amim I, Sefer ha-'Ibbur and Liber de rationibus tabularum, ${ }^{30}$ on the other. The signature of Ibn Ezra is also felt in that Part I poses and solves the problem in terms of « revealing a secret $» \cdot{ }^{31}$ For more details about the connection between the sixth chapter of Part I, and particularly about

27 See Part III, §13:1.

28 See Part I, \$5.3:1-28. Note that in this list precisely six lunar mansions are labelled humid (no. 4, $12,16,17,22,27)$ and five lunar mansions are labelled temperate humid (no. 7, 10,15, 19, 20)

29 See Part I, §6.1:1-7; §6.3:1-15; cf. 'Olam I, ed. SelA, §17:1-12, p. 62-63; Moladot, ed. SELA, IV 1:1-9, p. 182-185; Te'amim I, ed. SeLA, \$2.12:4-5, p. 50-51; Sefer Ha'ibbur, in Sefer Ha'ibbur: A Treatise on the Calendar by Rabbi Abraham Ibn Ezra, ed. and trans. MoRDECHAI S. GoodmAn, Ktav, Jerusalem 2011, p. 56-57 (Hebrew part) and p. 95-98 (English part); 'Iggeret ha-Shabbat, in The Sabbath Epistle of Rabbi Abraham Ibn Ezra: 'Iggeret haShabbat, ed. and trans. MORDECHAI S. GoodmAn, Ktav, Jerusalem 2009, p. 9-10; Ibn Ezra's comm. on Lev. 25:9 quoted and translated in SHLomo SeLA, Abraham Ibn Ezra and the Rise of Medieval Hebrew Science, Brill, Leiden 2003 (Brill's Series in Jewish Studies, 32), p. 274275, 373-374; Liber de rationibus tabularum, in El libro de los fundamentos de las Tablas astronómicas de R. Abraham Ibn 'Ezra, ed. José M. ${ }^{A}$ Millás VallicrosA, CSIC, Madrid 1947 (Instituto Arias Montano, Ser. D, 2), p. 75-76.

30 See Part I, §6.2:1-9; cf. Téamim I, ed. SELA, §2.12:7, p. 50-51; Sefer ha-'Tbbur, p. 67-68 (Hebrew part) and p. 122-123 (English part); Liber de rationibus tabularum, ed. Millas Vallicrosa, p. 77.

31 See Part I, §6.3:1; cf. TTéamim II, ed. SELA, §6.2:6, p. 236-237. 
Shlomo Sela, Carlos Steel, C. Philipp E. Nothaft, David Juste \& Charles Burnett

the astronomical parameters of this chapter, readers are invited to consult the next section of the introduction.

7. The seventh chapter of Part I - about calculating the horoscopes of the great conjunction Saturn-Jupiter of 1067 - has no counterpart in Ibn Ezra's oeuvre. However, it is important to take into consideration two points. First, as a rule, some versions of a book by Ibn Ezra incorporate idiosyncratic features that do not occur in the other versions of the same book. Second, in the last part of his career Ibn Ezra resided in the region of London, and during his stay in England he wrote highly specialized astronomical treatises and translations, such as Iggeret haShabbat ('the Epistle on the Sabbath'), a calendrical monograph, and the Hebrew translation of Ibn al-Muthannä's Commentary on the Astronomical Tables of alKhwārizmi.$^{32}$ Hence, it is plausible that during his stay in England, Ibn Ezra was commissioned by a Jew from Winchester to compose a work on world astrology with highly specialized astronomical data. As will be shown below, the Hebrew source text behind Part I was composed precisely in the last part of Ibn Ezra's career, and this fits well with the aforementioned scenario. Readers are also invited to consult the section of the introduction entitled «The Tables of Winchester ", which discusses the links between Ibn Ezra and the seventh chapter of Part I, and argues that Ibn Ezra compiled the astronomical tables mentioned in this chapter.

\section{I.1.2.}

That Part I is the Latin translation of an underlying Hebrew text, and not an original Latin composition or compilation of Latin texts, is borne out by the presence in the Latin text of the following features. (i) Hebraisms such as honor, sinistra and dextra, calques of שמאלי ,כבוד, which denote respectively the magnitude of a fixed star, and the northern and southern cardinal directions. (ii) Interpolations by the Hebrew or Latin translator indicating that the text underlying the Latin translation was originally composed in Hebrew. This emerges from the following descriptions of the $21^{\text {st }}$ and $22^{\text {nd }}$ lunar mansions:

Albalda et est in similitudine littere que apud Hebreos uocatur Heez subuerse. $=a l-$ balda, it is in the likeness of the letter that the Hebrews call het but reversed. ${ }^{33}$

Saadebach, et est hoc difficile scribere in lingua Hebrayca et significat eufortunium carnificis seu decollatoris. = sa'd al-dhäbih, and this is difficult to write in Hebrew, and it means the luck of the butcher or slaughterer. ${ }^{34}$

32 See Shlomo Sela, Gad Freudenthal, «Abraham Ibn Ezra's Scholarly Writings: A Chronological Listing », Aleph, 6 (2006), items 59 and 60, p. 46-47.

33 Part I, §5.2:21.

34 Part I, §5.2:22. 
We have seen above that Part I bears striking similarities to different parts of Ibn Ezra's work, as if it were the Latin translation of an unknown work by Ibn Ezra. Let us now identify this work.

Chapter six of Liber Electionum (henceforth Electiones), the Latin translation of the lost third version of Ibn Ezra's Sefer ha-Mivharim (henceforth Mivharim III) offers an account of the significations of each of the 28 lunar mansions according to the method of elections. ${ }^{35}$ The chapter begins with a theoretical introduction about the 28 lunar mansions, at the end of which we read: «Et in Libro iurium seculi explanabo formam mansionum » = «In the Book of the Judgments of the World, I will explain the shape of the mansions $"{ }^{36}$ This is the typical form in which Ibn Ezra directs the reader from one of his Hebrew astrological treatises to consult another of his Hebrew astrological writings. Liber iurium seculi, or Liber iudiciorum seculi, as Electiones refers to the same book a few lines later regarding the first lunar mansion, ${ }^{37}$ is a literal Latin rendering of Sefer Mishpetei ha-'Olam, an alternative name for Ibn Ezra's Sefer ha-'Olam. ${ }^{38}$

This cross-reference from Mivharim III cannot refer to 'Olam I or 'Olam II because neither of them includes a complete list of the 28 lunar mansions nor any reference to "the shape of the mansions ", = formam mansionum, an expression which in this context means a graphical representation of the asterisms of each of the mansion. ${ }^{39}$ It emerges then that this future-tense cross-reference from Mivharim III certainly points to an account of the lunar mansions in the hitherto unknown 'Olam III. That Part I is in all likelihood the Latin translation of the lost 'Olam III referred to in Mivharim III is indicated by the fact that, as shown above, each of the items in the first complete list of the 28 lunar mansions found in the fifth chapter of Part I is accompanied by a graphical representation of the asterisms of the corresponding lunar mansion. ${ }^{40}$

We have seen that this list of Part I is a close replica of the list of lunar mansions found in chapter 17 of Abraham Bar Hiyya's Hešbon mahalakhot ha-kokhavim ('Calculation of the stellar motions'). ${ }^{41}$ However, a scrutiny of the Latin terminology of chapter five of Part I reveals that the translator made frequent use of honor, ${ }^{42}$ a calque of kavod, used by Ibn Ezra in all his star lists to denote the

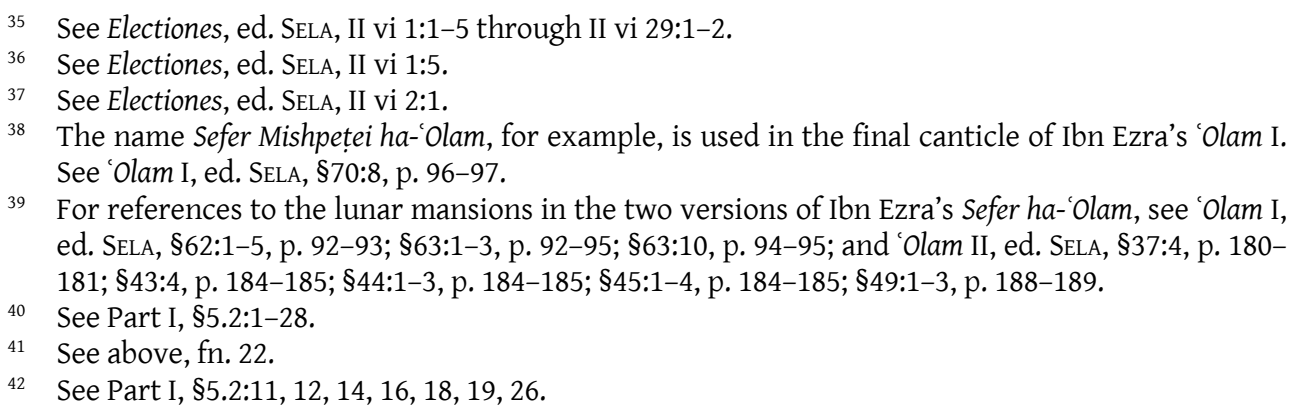

39 For references to the lunar mansions in the two versions of Ibn Ezra's Sefer ha-'Olam, see 'Olam I, ed. SELA, §62:1-5, p. 92-93; §63:1-3, p. 92-95; §63:10, p. 94-95; and 'Olam II, ed. SELA, §37:4, p. 180181 ; §43:4, p. 184-185; §44:1-3, p. 184-185; §45:1-4, p. 184-185; §49:1-3, p. 188-189. 
magnitude of stars and never used by Abraham Bar Hiyya with this meaning. ${ }^{43}$ So, either Ibn Ezra copied into 'Olam III this list of lunar mansions from Bar Hiyya's Hešbon mahalakhot ha-kokhavim, or, more plausibly, both Bar Hiyya and Ibn Ezra derived their lists from a common unknown Arabic source.

Further evidence of the existence of 'Olam III is provided by another future tense cross-reference about the great conjunctions from Liber Nativitatum (henceforth Nativitates), the Latin translation of the lost second version of Ibn Ezra's Sefer ha-Moladot (henceforth Moladot II) to certain $<$ Liber de $>$ verbis iurium seculi, which is also a literal Latin rendering of Sefer Mishpetei ha-'Olam, an alternative name for Ibn Ezra's Sefer ha-'Olam. ${ }^{44}$ That Part I is in all likelihood a Latin translation of the lost 'Olam III is also indicated by the fact that, as shown above, the third and seventh chapters of Part I address the great conjunctions of Saturn and Jupiter.

Since Moladot II was composed in $1158^{45}$ and Mivharim III in 1158 or after ${ }^{46}$ and since 'Olam III is referred to from these two works by future tense cross-references, it emerges that the Hebrew source text behind Part I - i.e., the lost 'Olam III - was also composed in 1158 or after, in the last stage of Ibn Ezra's career, when Ibn Ezra resided in the region of London or Rouen.

To sum up: the hitherto unknown existence of 'Olam III is conclusively established by a future-tense cross-reference from Mivharim III, in which Ibn Ezra says that in the Book of the Judgments of the World he will explain «the shape of the mansions ", and by the fact that neither 'Olam I or 'Olam II includes a complete list of the 28 lunar mansions nor any reference to «the shape of the mansions ». That Part I is a Latin translation of the lost 'Olam III is particularly implied (a) by the fact that each of the items in the first complete list of the 28 lunar mansions found in the fifth chapter of Part I is accompanied by a graphical representation of the asterisms of the corresponding lunar mansion, and also (b) by a note at the end of the second list of lunar mansions in which the translator acknowledges that the Hebrew original of the second list of lunar mansions, and presumably that of all of Part I, were composed by Abraham Ibn Ezra, (c) by that there are striking resemblances between the bulk of Part I and various parts of Abraham Ibn Ezra's work, and (d) by the repetitive use of honor, a calque of kavod, used by Ibn Ezra in all his star lists to denote the magnitude of a star. However, we can be rather

43 See Sela, Abraham Ibn Ezra's Introductions to Astrology, p. 296-297.

44 See Nativitates, ed. SELA, I i 3:9, p. 82-83: «Et hoc est necessarium scire maxime in verbis coniunctionum magnorum sicut explanabo in Verbis Iurium Seculi $»=$ «<All $>$ this is necessary to know, particularly regarding affaires related to the great conjunctions, as I will explain in the Book of the Judgments of the World».

45 See SELA, Abraham Ibn Ezra Latinus on Nativities, p. 43-45.

46 The date of composition of Mivharim III follows from a past tense cross-reference in Electiones that unmistakably points to a chapter on elections in Moladot II. See Electiones, ed. SELA, I 7:3. Since Moladot II was composed in 1158, it follows that Mivharim III was composed in 1158 or after. 
certain that Part I is not a complete Latin translation of 'Olam III. For one thing, the opening or closing canticles that characterize Ibn Ezra's astrological treatises, are absent from this Latin text. The size of this translation (only 3,700 words) is considerably shorter than that of any of Bate's other complete translations of Ibn Ezra's astrological works. Moreover, since we do not have the Hebrew original of 'Olam III, we cannot be certain that the seven chapters of Part I do not include additions or omissions made by copyists or translators in the transmission of 'Olam III. This applies particularly to the seventh chapter and to the horoscopes, which are without parallel in Ibn Ezra's work. In particular, as pointed out in section I.4 (see below p.223), casting horoscopes for the entry of the Sun into Aries, stands in sharp contradiction to Abraham Ibn Ezra, who resorts to syzygy horoscopes only and strongly rejects the horoscope of the Sun's entry into Aries.

\section{I.2. Astronomical Parameters in Part I, $\$ 6$ and Their Connection with Ibn Ezra (C. Philipp E. Nothaft)}

Between the chapter on lunar mansions (\$5) and the summary of astronomical calculations for the year 1067 (\$7), Part I inserts a discussion of the length of the solar year and the rate of precession, two closely interlinked parameters that were a major source of disharmony within the tradition of Graeco-Arabic astronomy. The discussion begins (\$6.1:2) with the assertion that there was agreement among the ancients that a solar year lasts $3651 / 4+1 / 120$ days, which is equivalent to 365 complete days with a rotational excess of $93^{\circ}\left(=[1 / 4+1 / 120] \times 360^{\circ}\right)$. There is a clear parallel here between our text and Abraham Ibn Ezra's Sefer ha-Moladot, where this year length is attributed to the Indians (אנשי הודו). ${ }^{47}$ The same is true of his Liber de rationibus tabularum (henceforth: LRT), which leads off its discussion of the solar year with an identical set of values, attributing it to the " wise men of India » (sapientes Indie)..$^{48}$ Another attestation of this Indian year length appears in the anonymous text starting Ptolomeus et multi sapientum (c.1145), which like the LRT was written to accompany Ibn Ezra's Tables of Pisa. ${ }^{49}$ In the LRT, Ibn Ezra

47 Moladot, ed. Sela, IV 1:1, p. 182.

48 Liber de rationibus tabularum, ed. Millas Valuicrosa, p. 75: "Sapientes vero Indie secundum dies mundi, quos dies apellant dies de Scindehind, omnes in hoc consentiunt quod annus solaris, ultra fractionem quadrantis, $120^{\mathrm{m}}$ partem diei continet, que est $5^{\mathrm{a}}$ pars unius hore, et erit revolucio anni solaris cum augmento 3 graduum, et secundum indos composite sunt tabule Alcaurezmi et Abnezafar et Mezlame ».

49 MS Cambridge, Fitzwilliam Museum, McClean 165, fol. 67r: «Indi autem metiuntur annum solarem secundum stellas fixas, dicentes annum solis esse reditum de stella fixa ad eandem, utpote a stella fixa in initio signi Arietis ad eandem, vel a loco alto ad locum altum, et dicunt annum habere 365 dies et 6 horas et partem diei centesimam vicesimam ». Ibid., fol. 67v: « Unde secundum Ptolomeum minuitur ab anno Christianorum pars trecentesima et secundum Indos additur pars 120 ». This is Text II in RAYMond MERCIER, «The Lost Zij of al-Șūfī in the Twelfth- 
Shlomo Sela, Carlos Steel, C. Philipp E. Nothaft, David Juste \& Charles Burnett

claims that the solar year of the Indians underlies tables drawn up by Alcaurezmi, Abnezafar and Mezlame..$^{50}$ The first of these names clearly refers to al-Khwārizmī, who in the first half of the ninth century adapted an earlier translation of astronomical tables from Sanskrit known as the Zij al-Sindhind. Upon its arrival in al-Andalus, the Khwārizmian version of the Zij al-Sindhind was revised again by Maslama al-Majrīṭi (d. 1007/8) and his student Ibn al-Ṣaffār (d. 1035), who must be the other two individuals on Ibn Ezra's list. ${ }^{51}$ One of the tables in this set operates with a year length of $365 \mathrm{~d} 6 ; 12,9 \mathrm{~h}=365 ; 15,30,22,30 \mathrm{~d}$ and a rotational excess of $93 ; 2,15^{\circ} .{ }^{52}$ If these values are rounded to $365 \mathrm{~d} 6 ; 12 \mathrm{~h}=365 ; 15,30 \mathrm{~d}$ and $93^{\circ}$ respectively, the result is equivalent to the $3651 / 4+1 / 120$ days mentioned in our text..$^{53}$

Century Tables for London and Pisa ", in ID., Studies on the Transmission of Medieval Mathematical Astronomy, Ashgate, Aldershot 2004 (Variorum Collected Studies Series, 787), ch. 8, p. 15-16. A portion of this text also appears in MS Oxford, Bodleian Library, Selden supra 26, fol. $122 \mathrm{r}-129 \mathrm{v}$, 101r-105v (reversed quires). On the Tables of Pisa and their connection with Ibn Ezra, see MERCIER, « The Lost Zij »; Charles Burnett, « Abd al-Masīh of Winchester », in Lodi Nauta, ARjo VAnderJagt (eds.), Between Demonstration and Imagination: Essays in the History of Science and Philosophy Presented to John D. North, Brill, Leiden 1999 (Brill's Studies in Intellectual History, 96), p. 159-169 (164-165); BURNETT, « Latin Alphanumerical Notation, and Annotation in Italian, in the Twelfth Century: MS London, British Library, Harley, 5402 », in MENSO FolKERTS, RICHARD LORCH (eds.), Sic itur ad astra: Studien zur Geschichte der Mathematik und Naturwissenschaften; Festschrift für den Arabisten Paul Kunitzsch zum 70. Geburtstag, Harrassowitz, Wiesbaden 2000, p. 77-90 (78-81); BURNETT, «Indian Numerals in the Mediterranean Basin in the Twelfth Century, with Special Reference to the 'Eastern Forms' ", in Yvonne Dold-Samplonius, Joseph W. Dauben, Menso FolKerts, Benno van Dalen (eds.), From China to Paris: 2000 Years Transmission of Mathematical Ideas, Franz Steiner Verlag, Stuttgart 2002 (Boethius, 46), p. 237-288 (251); BURNETT, « The Transmission of Arabic Astronomy via Antioch and Pisa in the Second Quarter of the Twelfth Century ", in JAN P. HogendiJK, ABdelhamid I. SabRa (eds.), The Enterprise of Science in Islam: New Perspectives, MIT Press, Cambridge (Mass.) 2003, p. 23-51 (36-38).

50 See fn. 48 above.

51 See Otto Neugebauer, The Astronomical Tables of Al-Khwārizmī, Munksgaard, København 1962 (Det Kongelige Danske Videnskabernes Selskab, Historisk-filosofiske Skrifter, 4.2); RAYMOND MERCIER, "Astronomical Tables in the Twelfth Century », in CHARLEs BuRnETT (ed.), Adelard of Bath: An English Scientist and Arabist of the Early Twelfth Century, The Warburg Institute, London 1987 (Warburg Institute Surveys and Texts, 14), p. 87-118 (88-94); DAVID PINGREE, « Indian Astronomy in Medieval Spain », in Josep CASUlLeRAS, Julio SAmsó (eds.), From Baghdad to Barcelona: Studies in the Islamic Exact Sciences in Honour of Prof. Juan Vernet, vol. I, Instituto « Millás Vallicrosa » de Historia de la Ciencia Arabe, Barcelona 1996, p. 39-48; DAVID A. KInG, Julio SAmsó, « Astronomical Handbooks and Tables from the Islamic World (750-1900): An Interim Report », Suhayl, 2 (2001), p. 9-105 (32-35, 56-57).

52 Ezich Elkaurezmi (trans. ADELARD OF BATH), in Die astronomischen Tafeln des Muhammed ibn Mūsā alKhwārizmī in der Bearbeitung des Maslama ibn Ahmed al-Madjrịtī und der latein. Übersetzung des Athelhard von Bath, ed. HeinRich Suter, A. F. Høst \& Søn, København 1914 (Det Kongelige Danske Videnskabernes Selskab, Skrifter, 7th Ser., Historisk og filosofisk Afd., 3.1), p. 230; NEUGEBAUER, The Astronomical Tables, p. 131.

53 See on this point JuLIo SAmsó, « 'Dixit Abraham Iudeus': algunas observaciones sobre los textos astronómicos latinos de Abraham Ibn ‘Ezra », Iberia Judaica, 4 (2012), p. 171-200 (179). 
In the LRT, the next estimate to be mentioned after the Indian one is that of the "wise men of the Persians", whom Mescella and Albumazar followed in constructing their tables. Their year is claimed to exceed $3651 / 4$ days by $1 / 115$ of a day. ${ }^{54}$ There is again a parallel passage in Ibn Ezra's Sefer ha-Moladot, where he equates the same « Persian » year length with a rotational excess of $93 ; 15^{\circ} .{ }^{55}$ These values are not strictly speaking compatible, as a year of $3651 / 4+1 / 115$ days implies a rotational excess of $93 ; 7,49 . .^{\circ}$ rather than $93 ; 15^{\circ}$. The fact that our text states that the Persians added $0 ; 15^{\circ}$ to the rotational excess of $93^{\circ}$ implied by the Indian value (Part I, §6.1:3) hence strengthens its connection to Ibn Ezra.

Part I remains in lockstep with the LRT for the third value on the list (\$6.1:4), which is Ptolemy's year of $3651 / 4-1 / 300$ days with a rotational excess of $88 ; 48^{\circ} .^{56}$ The author of our text expresses this excess as $90^{\circ}-1 ; 12^{\circ}$ but otherwise offers no information that would diverge from that given in the LRT. He then goes on to claim that astronomers subsequent to Ptolemy further decreased the year length to $3651 / 4-1 / 120$ days (\$6.1:5), which if compared to the Indian value of $3651 / 4+$ $1 / 120$ days would cause a discrepancy of one day in 60 years (\$6.1:6). No year of $3651 / 4-1 / 120$ days $(=365 \mathrm{~d} 5 ; 48 \mathrm{~h})$ is mentioned anywhere in the LRT, but it does crop up in the aforementioned Ptolomeus et multi sapientum, where it serves as a reckoning example in a detailed account of how to construct astronomical tables similar to the Tables of Pisa. ${ }^{57}$ It is endorsed as the year of the " astronomers » in an anonymous text starting Inter omnes recte philosophantes (1169), which shows strong signs of being dependent on Ptolomeus et multi sapientum. ${ }^{58}$ Even though this text gives the length of the tropical year as $365 \mathrm{~d} 5 ; 48 \mathrm{~h}$, which is the same as 365 $1 / 4-1 / 120$ days, it treats it as equivalent to $3651 / 4-1 / 131$ days, which is the approximate year length used in the Tables of Pisa. ${ }^{59}$ It hence seems likely that the length of $3651 / 4-1 / 120$ days, which is also cited in Latin computistical sources such as the Compotus Petri of $1171,{ }^{60}$ originated as a simplification of the Pisan value, which is equivalent to appr. $365 \mathrm{~d} 5 ; 49 \mathrm{~h}$ (rather than $365 \mathrm{~d} 5 ; 48 \mathrm{~h}$ ). The relevant passage in Part I, §6.1:6, offers a slight hint as to what may have motivated such a

54 Liber de rationibus tabularum, ed. Millás VallicrosA, p. 75, 1. 7-9: « Sapientes vero persarum asserunt additamentum supra $4^{\mathrm{am}}$ diei esse $115^{\mathrm{m}}$ partem diei, et secundum eos Mescella et Albumazar suas tabulas composuerunt ».

55 Moladot, ed. SelA, IV 1:2, p. 182.

56 Liber de rationibus tabularum, ed. Millás VAlLicRosa, p. 75, 1. 10-12: « [E]t Ptholomeus probavit illam fractionem minorem esse $4^{\mathrm{a}}$ parte tantum quantum valet $300^{\mathrm{ma}}$ pars unius diei, et erit anni revolucio secundum eum 88 graduum et 48 minutorum ».

57 MS Cambridge, Fitzwilliam Museum, McClean 165, fol. 68v-69r.

58 This text has so far only been found in MS Parma, Biblioteca Palatina, 718-720, fol. 422v-423v (s. XIII/XIV).

59 Ibid., fol. 423r-v.

60 See C. Philipp E. Nothaft, Scandalous Error: Calendar Reform and Calendrical Astronomy in Medieval Europe, Oxford University Press, Oxford 2018, p. 97-98, 103, 121-125. 
Shlomo Sela, Carlos Steel, C. Philipp E. Nothaft, David Juste \& Charles Burnett

simplification in the present case: if the lowest estimate of the year is treated as a mirror image of the highest, such that $3651 / 4-1 / 120$ days are pitted against the «Indian » value of $3651 / 4+1 / 120$ days, then it becomes very easy to calculate that it will take 60 years for the discrepancy to amount to a full day.

Up to this point, our text has made no express distinction between values based on the sidereal year (i.e., those longer than 365 1/4 days) and those representing the length of the tropical year (i.e., those shorter than $3651 / 4$ days). This distinction is finally supplied in $\$ 6.3$, while $\$ 6.4$ follows up by remarking on the two definitions of the signs of the zodiac that result from it. At the very end we are told that the sidereal zodiac was invented by the Indians of old, who based themselves on the visible constellations (\$6.4:3), which is a claim familiar from the LTR. $^{61}$

Before we get there, however, the text first comments on the access-and-recess motion of the sphere of fixed stars, which is alleged to be an Indian invention (\$6.2). We are told that there are two versions of this particular theory, depending on whether the amplitude of precession is taken to be $8^{\circ}$ or $10 ; 45^{\circ}(\$ 6.2: 2-4) .^{62}$ The same information appears in the LRT, where Ibn Ezra asserts that the access-andrecess theory was derided by Ptolemy and all the magistri probationum. ${ }^{63}$ By writing sed hoc nichil est (\$6.2:5), our text implicitly agrees with these astronomers that the theory imagined by the Indians fails to correspond to reality.

The text goes on to assert that Ptolemy's date of the vernal equinox in his own day fell eight days later than the Sun's entry into Aries according to the Indians, which is hence implied to be a sidereal sign-entry (\$6.2:6). We are further told that, in present times, the equinox is nine days ahead of the Indian calculation (\$6.2:8). A parallel passage in the LRT can be identified, although here the difference at the time of Ptolemy is said to have been seven, not eight, days. The LRT text is also clearer in stating that the Indian sign-entry was calculated using the tabulae Indorum. ${ }^{64}$ According to the tables of al-Khwārizmī, the true Sun reached the first

${ }_{61}$ Liber de rationibus tabularum, ed. Millás Valuicrosa, p. 83, 1. 24-p. 84, 1. 4; p. 85, 1. 5-15. Further such passages occur in Ptolomeus et multi sapientum, MS Cambridge, Fitzwilliam Museum, McClean 165, fol. 67r; Inter omnes recte philosophantes, MS Parma, Biblioteca Palatina, 718-720, fol. 423v.

62 For more information on these parameters, see C. PHILIPP E. NothAFT, Walcher of Malvern: 'De lunationibus' and 'De Dracone'; Study, Edition, Translation, and Commentary, Brepols, Turnhout 2017 (De Diversis Artibus, 101 [N.S. 64]), p. 285-290; NothAFT, « Ptolemaic Orbs in Twelfth-Century England: A Study and Edition of the Anonymous Liber de motibus planetarum », Mediterranea, 3 (2018), p. 145-210 (157-161); NotHAFT, Scandalous Error, p. 100-101.

63 Liber de rationibus tabularum, ed. Millás VAlLICROSA, p. 77, 1. 3-11. On the magistri probationum, see SAMsó, " 'Dixit Abraham Iudeus' », p. 193-195.

64 Liber de rationibus tabularum, ed. Millás Vallicrosa, p. 81, 1. 20-28: « Nam si quis velit coequare planetas in tabulis indorum secundum tempus Ptholomei, inveniet solem intrasse caput arietis 7 diebus ante illum diem in quo intrare Ptholomeus probavit illum. Si autem velimus equare solem cum intrat caput arietis secundum magistros probationum vel cum alibi est in nostro tempore, inveniemus eum intrare caput arietis 9 diebus ante illum diem in quo secundum tabulas indorum 
degree of Aries on 14 March in AD 140 (i.e., in Ptolemy's day) and on 23 March in $\mathrm{AD} 1154$, which is the annus praesens of the LRT. It is worth comparing these datapoints with a passage in Ptolomeus et multi sapientum, which puts the present-day equinox on $14 \mathrm{March}$, as would have been correct for most of the middle years of the twelfth century. It also gives the corresponding Indian sign-entry on 23 March while claiming that the dates were exactly reversed in Ptolemy's day (vernal equinox on 23 March and Indian sign-entry on 14 March). ${ }^{65}$ This statement clashes with Ptolemy's Almagest (III.1), which records the vernal equinox of AD 140 for 22 March rather than 23 March, as do the corresponding astronomical tables. In our text, by contrast, the discrepancy between Ptolemy and the Indians is said to be eight days, exactly the interval one could find by comparing the Almagest and alKhwārizmī's tables.

Commenting on the divide between users of a tropical reference frame and those preferring sidereal coordinates, the text (\$6.3:4) cites three different estimates for the linear rate of precession: $1^{\circ} / 100 \mathrm{y}, 1^{\circ} / 70 \mathrm{y}$, and $1^{\circ}$ in 66 years and 8 months. A very similar array of values appears in the LRT, where we are told that Ptolemy postulated a motion of $1^{\circ}$ every 100 years, whereas al-Battānī showed it to be $1^{\circ} / 66 \mathrm{y}$ and al-Ṣufî later claimed it was $1^{\circ} / 70 \mathrm{y} .{ }^{66}$ Our text renders the second of these three values more precise, giving it as $1^{\circ}$ in 66 years and 8 months, which is the same as $1^{\circ} / 66 ; 40 \mathrm{y}$. It is the exact value one can derive from another statement in the LRT according to which the total period of precession is 24,000 years $(24,000 \div 360=66 ; 40){ }^{67}$

In $\S 6.3: 5$ one is told that the length of the anomalistic year (a puncto ad eundem punctum) is the same as the sidereal year, since the precession of the apogee is equivalent to that of the fixed stars. This statement fully conforms to Ibn Ezra's

intrare invenietur, et hoc quidem negari non potest cum possit fieri huius rei manifestatio et per astrolabium et per umbram ». See also ibid., p. 86, 1. 11-19; 'Olam I, ed. SELA, §11:3, p. 58; 'Olam II, ed. SELA, §45:4, p. 184; Ibn al-Muthannā, Commentary on the Astronomical Tables of al-Khwārizmī (trans. Abraham Ibn Ezra), in Ibn al-Muthannâ's Commentary on the Astronomical Tables of al-Khârizmî, trans. BeRnARd R. Goldstein, Yale University Press, New Haven (Conn.) 1967, p. 149, 1. 31-32.

65 MS Cambridge, Fitzwilliam Museum, McClean 165, fol. 67v: « Ex his predictis nichilominus patet racio secundum quam in diebus Ptolomei cum sol intraret capud Arietis, scilicet iuncturam in lineam equinoctialem, <erat $>[\mathrm{ms}$. et $]$ in 23 diebus Martii, secundum Indos in 14 die Martii intrasse inveniretur, nunc econverso secundum rationem Ptolomei inveniatur sol intrare capud Arietis 14 die Martii, secundum Indos in 23 die Martii, quia Ptolomeus secundum iuncturam, Indi secundum stellam firmam annum faciunt. [...] Hinc itaque est quod secundum Ptolomeum, cum in anno Christianorum sol intret Arietem presenti tempore 14 die Martii, post intervalla annorum intrabit 13, deinde 12 die Martii, et cum secundum Indos intret sol presenti tempore 23 Martii in anno Christianorum, post temporis cursum magnum intrabit 24, et deinceps ».

66 Liber de rationibus tabularum, ed. Millás VAluicrosa, p. 78, 1. 6-10; SAMsó, « 'Dixit Abraham Iudeus' », p. 181.

67 Liber de rationibus tabularum, ed. Millás Vallicrosa, p. 81, 1. 16-17. 
Shlomo Sela, Carlos Steel, C. Philipp E. Nothaft, David Juste \& Charles Burnett

opinion, as recorded in the LRT. ${ }^{68}$ What follows is a rough calculation of the length of the sidereal year implicit in Ptolemy's rate of precession (\$6.3:7-10), which is again effectively the same as that in the LRT. ${ }^{69}$

The text's dependence on the LRT is less straightforward in the remainder of the discussion, which continues by attributing to the " wise men of the Saracens " a precession rate of $1^{\circ} / 66 \mathrm{y}$ with a corresponding rotational excess of $5 ; 27^{\circ}$ (§6.3:11). In the LRT, this set of values is associated with al-Battānì's tropical year of $3651 / 4-1 / 106$ days and a rotational excess of $90^{\circ}-3 ; 24^{\circ}=86 ; 36^{\circ},{ }^{70}$ whereas our text ( $86.3: 12-13)$ states that the Saracens chose a length of $3651 / 4-1 / 115$ days and a rotational excess of $90^{\circ}-3 ; 13^{\circ}=86 ; 47^{\circ}$. These numbers fail to add up, however, as the rotational equivalent of $1 / 115^{\text {th }}$ of a day should have been $3 ; 7,49 . .{ }^{\circ}$. Accepting the $3 ; 13^{\circ}$ in our text, which are confirmed by the $2 ; 24^{\circ}$ in $\$ 6.3: 13$ (since $3 ; 13^{\circ}+2 ; 24^{\circ}=5 ; 27^{\circ}$ ), one arrives at a year length of $3651 / 4-1 / 112$ days, which suggests that the number 115 in MS $V$ was an error for 112 . With this conjecture in place, the year length stated in \$6.3:12 comes extremely close to the solar parameter used in Henry Bate's Tables of Mechelen, which implies a tropical year of $365 \mathrm{~d} 5 ; 47,8,57,20 \ldots \mathrm{d}=3651 / 4-1 / 111.99 \ldots$ days. ${ }^{71}$ In light of Bate's involvement in rendering the tripartite text into Latin, this is unlikely to be a complete coincidence. At the same time, it remains an open question whether the $3 ; 13^{\circ}$ and $1 / 112^{\text {th }}$ of a day were an original element of our text. An interpolation on Bate's part seems equally possible, especially considering that a solar year of $3651 / 4-$ $1 / 112$ days is not otherwise attested in Abraham Ibn Ezra's written work.

The third precession rate to receive its concomitant tropical year in $\$ 6$ is $1^{\circ} / 70 \mathrm{y}$, which corresponds to a fractional excess of $5 ; 8,34 \ldots{ }^{\circ}$ or roughly $5 ; 9^{\circ}$, as stated both here (\$6.3:14) and in the LRT. ${ }^{72}$ Our text links this value to a larger group of Arabic astronomers, the aforementioned magistri probationum, whose tropical year is equivalent to 365 complete days and a rotational excess of $90^{\circ}-$ $2 ; 45^{\circ}=87 ; 15^{\circ}(\$ 6.3: 14)$. Converted into fractions of a day, this yields a tropical year of $3651 / 4-1 / 130.909090 \ldots$ days or very nearly $3651 / 4-1 / 131$ days. The result approximates the year length implicit in the Tables of Pisa, which is $365 \mathrm{~d}$ $5 ; 49,2,33,49 \ldots \mathrm{h}=3651 / 4-1 / 131.4 \ldots$ days. A rounded value of $365 \mathrm{~d} 5 ; 49 \mathrm{~h}=3651 / 4$ $-1 / 131$ days is in fact repeatedly endorsed in the Hebrew works of Abraham Ibn Ezra, for example in the first version of the Sefer ha-'Olam I, where it is labelled « the correct value for our era $»{ }^{73}$

68 Ibid., p. 79, 1. 21-p. 80, 1. 21. See SAmsó, « ‘Dixit Abraham Iudeus' », p. 182-184.

69 Liber de rationibus tabularum, ed. Millás Vallicrosa, p. 82, 1.16-29.

70 Ibid., p. 83, 1. 1-7.

71 C. Philipp E. Nothaft, «Henry Bate's Tabule Machlinenses: The Earliest Astronomical Tables by a Latin Author ", Annals of Science, 75 (2018), p. 275-303 (290-297).

72 Liber de rationibus tabularum, ed. Millás VAlLICROSA, p. 83, 1. 15-17.

73 'Olam I, ed. SELA, §17:9, p. 62-63. See also Țéamim I, ed. SeLA, \$2.12:5, p. 50; Téamim II, ed. SelA, \$6.3, p. 238; §8.2, p. 250; Moladot, ed. Sela, IV 1:9, 4.2, p. 184; Tequfah, ed. SELA, §1:3, 2:2, p. 372. 
A different picture emerges from the LRT, where the precession rate of $1^{\circ} / 70 y$ is instead associated with a tropical year of $365+87 ; 21 / 90=3651 / 4-1 / 135.8 \ldots$ days, which was supposedly championed by Islamic astronomers such as Ibn Yunus, al-Șūī, Azarquiel, and Ibn Sina. ${ }^{74}$ The text also makes the surprising assertion that the astronomical tables described in it, that is, the Tables of Pisa, assume a tropical year of $3651 / 4-1 / 136$ days « according to the observation of alȘûfī, Ibn Sina, and Azarquiel $\gg .{ }^{75}$ For this year length to result from a precession rate of $1^{\circ} / 70 y$, the rotational excess of the corresponding sidereal year would have to be approximately $87 ; 21^{\circ}+5 ; 9^{\circ}=92 ; 30^{\circ}$, as is indeed noted in the LRT. ${ }^{76}$ This translates into a sidereal year of $3651 / 4+1 / 144$ days. By contrast, the tropical year of $3651 / 4-1 / 131$ days assumed in our text and in other sources connected to the Tables of Pisa will result if the rate of $1^{\circ} / 70 \mathrm{y}$ is applied to a sidereal year of $3651 / 4$ $+1 / 150$ days (rotational excess of $\left.92 ; 24^{\circ}\right)$. The LRT and our text $(\$ 6.3: 10,15)$ agree in tracing this value back to Ptolemy. ${ }^{77}$

\section{I.3. The Tables of Winchester in Part I, §7 (C. Philipp E. Nothaft)}

\section{I.3.1. General remarks}

In the final chapter of Part I, the author spells out the results as well as some of the intermediary steps of astronomical calculations he performed with a set of tables of his own making (see the reference to tabulas quas ego composui in \$7.1:14). Their meridian of reference is revealed most clearly in his account of how he calculated the time of the vernal equinox of AD 1067 (\$7.1:3-12). Having used the tables to find the Sun's mean motion in 1066 years, he adjusted this result to the meridian of Arin (Ujjain in India), which medieval astronomers assumed to lie on the equator and on the prime meridian that marked the " middle of the world» $(\S 7.1: 4){ }^{78} \mathrm{He}$

74 Liber de rationibus tabularum, ed. Millás Vallicrosa, p. 83, 1. 9-15.

75 Liber de rationibus tabularum, ed. Millás Valuicrosa, p. 95, 1. 12-15: « Superius ergo docuimus quod secundum rationem harum tabularum annus 365 dies continet et quartam, centesimam sextam partem diei minus, et hoc secundum probationem Azofi et Abencinne et Acerchel ». The year length given in the edition must be emended to $3651 / 4-1 / 136$ days, as found in MS Oxford, Bodleian Library, Digby 40, fol. 61r (s. XII ${ }^{2 / 2}$ ): « ... annus 365 dies continet et quartam centesimam $36^{\text {ta }}$ parte [sic] diei minus ». See the discussion in G. J. TOOMER, « The Solar Theory of az-Zarqāl: A History of Errors », Centaurus, 14 (1969), p. 306-336 (317-319).

76 Liber de rationibus tabularum, ed. Millás VAluicrosa, p. 83, 1. 17.

77 Ibid., p. 82, 1.23-29.

78 On the position of Arin, see IBN AL-MutHAnNĀ, Commentary on the Astronomical Tables of al-Khwārizmī (trans. Abraham Ibn Ezra), trans. Goldstein, p. 147, 1. 27-p. 148, 1. 1; Petrus Alfonsi, Dialogus, vol. I, ed. Carmen Cardelle de Hartmann, Darko Senekovic, Thomas Ziegler, and Peter Stotz, Sismel Edizioni del Galluzzo, Florence 2018, p. 30-40 (tit. 1.36-71); RAYMOND DE MARSEILlE, Liber cursuum planetarum, in Opera omnia, vol. I, ed. Marie-Thérèse d’Alverny, Charles Burnett, EMmanuel Poulle, 
did so by lowering the original value by $0 ; 11,40^{\circ}$, which approximates the mean solar motion for the time difference between Winchester and Arin (\$7.1:4-5). The author is explicit in naming Winchester as his present location (\$7.1:12) and references the city again at the end of this section, where he notes the ascendant degree at the lunisolar opposition of 26 August 1067 (\$7.1:22). Since the only other place mentioned in this chapter is Arin, it seems very likely that all of the computational results presented in it were derived from the same set of tables for the coordinates of Winchester.

The use of Winchester tables in Part I of our text may explain a reference in Henry Bate's undated treatise on the equatorium, in which tables for Winchester are listed alongside the Tables of Pisa as examples of astronomical tables cast for tropical longitudes in the ninth sphere. From the way the text mentions the two sets immediately after the tables of «Abraham » it appears that Bate intended to classify them both as works by Abraham Ibn Ezra or Abraham Iudeus. ${ }^{79}$ Bate knew about Ibn Ezra's authorship of the Tables of Pisa from the Liber de rationibus tabularum, which had been written to elucidate the tables in question. ${ }^{80}$ That he was directly familiar with the Tables of Pisa is evident from his own tables for the meridian of Mechelen, which follow the same structural outlines. In one of the

CNRS Éditions, Paris 2009 (Sources d'Histoire Médiévale, 40), p. 172 (I.62a-63a), 184 (I.82b), 200 (II.1a, 1d), 204 (II.3a); Ezich Elkaurezmi (trans. Adelard of Bath), ed. SUTER, p. 1; ADELARD OF BATH, De opere astrolapsus, in BRUCE GEORGE DICKEY, " Adelard of Bath: An Examination Based on heretofore Unexamined Manuscripts ", Ph.D. Diss., University of Toronto 1982, p. 164-165; HermanN OF Carinthia, De essentiis, ed. Charles BurnetT, Brill, Leiden 1982 (Studien und Texte zur Geistesgeschichte des Mittelalters, 15), p. 214, 1. 22-24 (bk. II, 77rD); 216, 1. 5-10 (bk. II, 77rF); The Toledan Tables, ed. Fritz S. Pedersen, 4 vols., C. A. Reitzel, København 2002 (Det Kongelige Danske Videnskabernes Selskab, Historisk-filosofiske Skrifter, 24.1-4), vol. I, p. 250 (Ca82); vol. II, p. 430 (Cb133), 730 (CcD133); vol. III, p. 1191-1197; Theorica planetarum Gerardi, ed. FRANCIS J. CARMODY, Berkeley (Ca.) 1942, p. 45 (c. 8, \$106); Rolando A. LAGUARDA TRIAS, La ciencia española en el descrubrimiento de America (las tablas de coordenadas geográficas compiladas en la España medieval), Casa-Museo de Colon y Seminario Americanista de la Universidad de Valladolid, Valladolid 1990 (Cuadernos Colombinos, 16), p. 23-25.

79 Henry BATE, Equatorium planetarum, in Opusculum Abrahe Iudei de nativitatibus cum exemplaribus figuris singulis domibus antepositis: Et magistralis compositio astrolabii Hanrici Bate, Erhardus Ratdolt, Venice 1485, sig. d4r-v: « Ptholemeus vero: et Geber: Albategni: Abrahamque Iudeus: et Açophius, ceteri quoque magistri probationum et maxime orientales astronomi motus planetarum secundum nonam speram considerantes radices suas super hoc fundaverunt: et hoc patet in tabulis Ptholomei: Albategni et Abrahe: in tabulis Pisanis, Wintoniensibus et aliis ». See BuRnETT, « Abd al-Masīh of Winchester », p. 163-164, 166.

80 See the quotation from the Liber de opere tabularum by Abraham Iudeus in HENRY BATE, Speculum divinorum et quorundam naturalium, XX.17, ed. CARLOS STEEL, GuY Guldentops, Leuven University Press, Leuven 1996 (Ancient and Medieval Philosophy, De Wulf-Mansion Centre, Series 1, 23), p. 337. See, in addition, the reference to Abraham and his Tractatus de motibus et opere tabularum in the introduction to ABRAHAM IBN EzRA, De revolutionibus (trans. Henry Bate), in Abrahe Avenaris Iudei Astrologi peritissimi in re iudiciali opera: ab excellentissimo philosopho Petro de Abano post accuratam castigationem in Latinum traducta, Petrus Liechtenstein, Venice 1507, fol. 77va. 
manuscripts, the Tables of Mechelen incorporate a second table for the mean anomaly of Mercury "according to Abraham Ibn Ezra» (secundum Abraham Evenzare), whose underlying parameter is that of the Pisan tables. ${ }^{81}$ Given Bate's role in translating our tripartite text into Latin, it may well be the case that his information concerning the parallel existence of Winchester tables came entirely from this one text and that he ascribed the tables to Ibn Ezra on its basis.

The hypothesis of Ibn Ezra's authorship seems to receive support from a marginal note added to a mid-thirteenth century copy of the Toledan Tables, which had been translated from Arabic into Latin in the twelfth century. ${ }^{82}$ In the top-left corner next to the standard tables for the Sun's mean motion, the annotator placed the following comment:

Know that the tables of the Sun's mean motion made by Abraham for the meridian of Winchester precede these tables by the mean motion of 9 days and 12 hours and 12 minutes of the hour. These same [tables] precede the tables made according to [the meridian of] Angers by 50 minutes of the hour. ${ }^{83}$

Another gloss on the same page tells us to add $9 ; 22,15^{\circ}$ to any mean longitude extracted from the present solar tables. ${ }^{84}$ It is clearly related to the previous remark, since $9 ; 22,15^{\circ}$ is the solar mean motion in $9 \mathrm{~d} 12 ; 12 \mathrm{~h}$ if the rate of motion is taken to be $0 ; 59,8^{\circ} / \mathrm{d}$ (the mean solar motion in the Toledan Tables is $0 ; 59,8,11,28,27^{\circ} / \mathrm{d}$, that in the Tables of Pisa is $0 ; 59,8,19,42,45,5^{\circ} / \mathrm{d}$ ). Analogous notes instructing users to add a certain amount to the radices in a given collectedyear table also appear in the margins of other pages of this manuscript. ${ }^{85}$ The full set of suggested additions is as follows:

$\begin{array}{ll}\text { Sun } & +9 ; 22,15^{\circ} \\ \text { Moon } & +11 ; 50^{\circ} \\ \text { Moon (arg.) } & +11 ; 50^{\circ} \\ \text { Saturn } & +9 ; 24^{\circ} \\ \text { Jupiter } & +10 ; 33,43^{\circ} \\ \text { Mars } & +7 ; 52,22^{\circ} \\ \text { Venus (arg.) } & +0 ; 24^{\circ} \\ \text { Mercury (arg.) } & +7 ; 48^{\circ}\end{array}$

81 Nothaft, « Henry Bate's Tabule Machlinenses », p. 283.

82 See The Toledan Tables, ed. PEDERSEN.

83 MS Cambridge, University Library, Kk.1.1, fol. 145v: « Scito quod tabule mediorum cursuum solis ad meridiem Winconiensem ab Abrahamo condite precedunt has tabulas mediis cursibus 9 dierum et 12 horarum et 12 minutorum hore. Ille eedem precedunt tabulas secundum Andegavum factas 50 minutis hore ».

84 Ibid.: « Adde cuilibet medio cursui de hac tabula mediorum cursuum solis extracto 9 gradus, 22 minuta, 15 secundas $»$.

85 Ibid., fol. 146r, 147v, 148v, 149r, 150r, 150v, 151v. 
Shlomo Sela, Carlos Steel, C. Philipp E. Nothaft, David Juste \& Charles Burnett

Dragon $\quad+4^{\circ}$

One hallmark of the Toledan Tables is their use of a sidereal frame of reference, which necessitates applying the so-called « equation of the eighth sphere » if tropical longitudes are sought. According to the access-and-recess model of variable precession inherent in these tables, the value of this "equation » was slightly more than $9^{\circ}$ at the beginning of $\mathrm{AD} 1250$. The recommended additions to the radices of the Sun $\left(9 ; 22,15^{\circ}\right)$ and most other planets (between $7 ; 48^{\circ}$ and $11 ; 50^{\circ}$ ) are hence broadly consistent with the claim, made by Henry Bate, that the Tables of Winchester were cast for tropical longitudes. What makes these glosses rather puzzling, however, is their failure to specify a date at which the stated addition is supposed to be valid. Instead, the gloss next to the solar tables is explicit in treating it as a constant that applies to any mean longitude calculated from these tables. ${ }^{86}$ For this to make sense, the Toledan Tables and Abraham's Winchester tables would have to be based on the same parameters, allowing the differences between their cyclical radices to remain constant over time. This cannot have been the case, however, if the Tables of Winchester used a tropical year, as they clearly did (see below).

Of the various known texts either written by Abraham Ibn Ezra himself or somehow derived from his works, the only one to mention the meridian of Winchester is the Tractatus Magistri Habrahe de tabulis planetarum, which is effectively a type of canons to the Tables of Pisa. ${ }^{87}$ The longitude of Pisa is here given as $33^{\circ}$ from the western prime meridian and contrasted with the joint longitude of Angers and Winchester, which is said to be $24^{\circ} .^{88}$ There is an obvious affinity between this passage and another one contained in Ibn Ezra's Liber de rationibus tabularum, which fully agrees with the Tractatus Magistri Abrahe as far as the coordinates of Pisa and Angers are concerned..$^{89}$ At the same time, one notices a tension between this Tractatus and $\$ 7$ of Part I in our tripartite text, where Winchester is placed $19^{\circ}$ east of the western prime meridian (rather than $24^{\circ}$ ) and $71^{\circ}$ west of the city of Arin (\$7.1:4). The same longitude is assigned to Winchester in a note accompanying the astronomical tables of al-Khwārizmī (in the version translated by Petrus Alfonsi) in MS Oxford, Corpus Christi College, 283 (s. XII). ${ }^{90}$ It

86 See fn. 84.

87 This is Text III in MERCIER, « The Lost Zij », p. 16-17.

88 See MS London, British Library, Arundel 377, fol. 56va, which is quoted in Liber de rationibus tabularum, ed. Millás Vallicrosa, p. 61.

89 Liber de rationibus tabularum, ed. Millás Vallicrosa, p. 87, 1. 20-21; p. 88, 1. 13-14. Note that the printed edition gives the longitude of Angers as $23^{\circ}$, which is inconsistent with the stated time difference of $0 ; 36 \mathrm{~h}\left(=9^{\circ}\right)$ between Pisa and Angers. The correct reading of $24^{\circ}$ is attested in MS Erfurt, Universitäts- und Forschungsbibliothek, Dep. Erf. CA $4^{\circ} 381$, fol. 4v (s. XII ${ }^{2 / 2}$ ).

90 Neugebauer, The Astronomical Tables, p. 229-230; John D. NoRTH, " The Longitudes of Winchester », Cahiers de l'Institut du Moyen-Âge Grec et Latin, 73 (2002), p. 13-20 (15); PATRICK GAUTIER DALCHÉ, « La 
is attested, moreover, as the longitude of London in one of the headings to the Tables of London, as found in MS London, British Library, Arundel 377, fols. 7v-35r (s. XII/XIII), which is the same manuscript that transmits the Tractatus Magistri Habrahe. The collected-year table for the mean Sun is here introduced as follows:

The mean motion of the Sun according to years of the Lord for London, whose longitude is 19 degrees. ${ }^{91}$

The Tables of London are known to be an adaptation of the Tables of Pisa, yet their relation to these original tables is unusually complicated. When John D. North compared the radices of both sets for an article published in 2002, he found that values in the London tables for the Moon, Mars, Venus, and Mercury are broadly consistent with the hypothesis that the original meridian was shifted by approximately $14^{\circ}$, which is what one might expect from a redactor who placed London at $19^{\circ}$ from the western meridian and Pisa at $33^{\circ}$. It turned out to be different for the Sun's radices, where the "inferred longitude difference [...] is close to $8^{\circ}$; and for the lunar tables it is close to $9^{\circ} \% .^{92}$ While the latter conclusion is difficult to verify owing to North's silence on the details of his calculations as well as to signs of corruption in the extant copies of the Pisan tables, ${ }^{93}$ his finding for the Sun is clearly sound. Applying the precise rate of mean motion implicit in the Pisan tables $\left(0 ; 59,8,19,42,45,5^{\circ} / \mathrm{d}\right)$ to the increase of $0 ; 1,28^{\circ}$ exhibited by the radices of the London Tables will indeed indicate a longitudinal shift of $c .8^{\circ}$. It should not be excluded, however, that the redactor of the London tables employed a simplified value of $0 ; 59,8^{\circ} / \mathrm{d}$, as displayed in the first line of the table for the daily mean motion..$^{94}$ If it was his intention to shift the meridian by $9^{\circ}$, as per the distance between Angers/Winchester $\left(24^{\circ}\right)$ and Pisa $\left(33^{\circ}\right)$ assumed in the Tractatus Magistri Habrahe, ${ }^{95}$ a rate of $0 ; 59,8^{\circ} / \mathrm{d}$ would have mandated increasing the radices by $0 ; 1,28,42^{\circ}$. It hence seems perfectly possible that the redactor proceeded in this way and simply ignored sexagesimal thirds.

It seems clear, in any case, that the surviving version of the Tables of London was not cast for a unified meridian. North accounted for this strange state of affairs by proposing that Abraham Ibn Ezra, following his arrival in England, initially

Terre dans le cosmos ", in Id. (ed.), La Terre: connaissance, représentations, mesure au Moyen Âge, Brepols, Turnhout 2013 (L'Atelier du Médiéviste, 13), p. 161-257 (236, 238, 240).

91 MS London, British Library, Arundel 377, fol. 7v: « Medius cursus solis ad annos Domini collectos super Londonias quarum longitudo est XIX graduum ».

92 NORTH, «The Longitudes of Winchester », p. 18.

93 See MERCIER, « The Lost Zij », p. 4, 24-25, were the Pisan values for the lunar anomaly are emended on the assumption that the London radices were based on a meridian-shift of $14^{\circ}$.

94 See, e.g., the copy of the Tables of Pisa in MS Vatican City, Biblioteca Apostlica Vaticana, lat. 3119, fol. 2 r.

95 See fn. 88 above. 
Shlomo Sela, Carlos Steel, C. Philipp E. Nothaft, David Juste \& Charles Burnett

adapted his Tables of Pisa to the meridian of Winchester but subsequently " underwent a change of mind » about its longitude as well as that of London, leading him to revise some of the mean-motion tables. ${ }^{96}$ When North presented this hypothesis in 2002, he was already aware of the Middle English translation of our tripartite text in MS L (see section III below), treating it as an indirect witness to Ibn Ezra's lost Tables of Winchester and their original reference meridian $14^{\circ}$ west of Pisa. ${ }^{97} \mathrm{He}$ withdrew from this position in an article published in 2003, in which he argued that the planetary positions mentioned in this text had been computed on the basis of some version of the Toledan Tables rather than a cognate of the Tables of Pisa. The clearly stated implication of this finding was that the calculations were not made by Abraham Ibn Ezra, but by « a different Winchester astronomer $» .^{98}$

A major deficit of North's study is that he carried it out on the sole basis of $L$, which leaves out crucial information found only in the Latin version contained in $V$. In $\$ 1.5$ of chapter 7 , this version offers a very strong prima facie reason for drawing a connection between the Winchester tables used by the author and Ibn Ezra's Tables of Pisa: the way the mean solar longitude on 1 March AD 1067 is expressed as a combination of 1049 collected and 17 expanded years. This style of presentation is alien to the Toledan Tables, at least in their standard version (which is based on the Arabic calendar), but it would have appeared natural to a user of the Tables of Pisa, which are based on collected-year cycles of 20 years. In its original state, the table of collected years began with AD 1029 (completed), such that the second radix was valid for 1049 (completed). ${ }^{99}$ To find the mean longitude on 1 March 1067, one had to add to this radix the entry for 17 years in the adjacent table of expanded years, exactly as indicated in our text. This parallel can hardly be a coincidence, as there is no other set of astronomical tables from the Latin Middle Ages that exhibits the combination of structural features indicated here, i.e., a beginning of the year on 1 March and the use of collected-year radices spaced by 20 years, with one of the radices valid for 1049 completed years of the Christian era.

That the mean longitudes contained in these tables were tropical rather than sidereal is abundantly clear from the way the calculation summarized in \$7.1:5-12 involved no equation of the eighth sphere, which would have been a necessary step for users of the Toledan Tables intent on finding the time of the vernal

\footnotetext{
NORTH, « The Longitudes of Winchester », p. 19.

Ibid., p. 13-14, 19-20.

John D. NorTH, « Winchester 1067 », Centaurus, 45 (2003), p. 130-141 (136).

9 That the collected-year tables in the Tables of Pisa began with 1029 (completed) is confirmed by the text Ptolomeus et multi sapientum, as found in MS Cambridge, Fitzwilliam Museum, McClean 165 , fol. 70r. A version of the tables matching this description appears in MS Vatican City, Biblioteca Apostolica Vaticana, lat. 3119, fol. 1v-42r.
} 
equinox. The same conclusion can be drawn from the author's approach to deriving the solar equation, for which purpose he adjusted the position of the solar apogee to the year 1067 . His starting point was a value of $86 ; 14^{\circ}$ for the year 1100 , which was recorded in his tables. From this he subtracted $0 ; 28^{\circ}$ to find the corresponding value for 1067 , which was $85 ; 46^{\circ}$ (\$7.1:7). Such an operation has no place in the Toledan Tables' sidereal frame of reference, as there the apogees remain fixed at the same longitude.

In contrast to the mean-motion tables for Winchester, which seem to have disappeared, the source the author used to adjust the solar apogee still survives in some twelfth- and thirteenth-century astronomical manuscripts. It is a list of planetary apogees for $\mathrm{AD} 1100$ (completed) accompanied by precession tables that could be used to adjust this value to other years of the Christian era. ${ }^{100}$ The tables assume an increase in apogeal longitude of $0 ; 0,51^{\circ}$ per year, which would yield $0 ; 28,3^{\circ}$ for a 33-year period. Our author probably performed the same calculation, but then disregarded the sexagesimal seconds. Implicit in this calculation is a precession rate of $1^{\circ} / 70 y$, the value that our text associates with the tropical year of $3651 / 4-1 / 131$ days employed by the Tables of Pisa ( $\$ 7.3: 14$ ). The nexus between this particular precession value and the Tables of Pisa is preserved in MS København, Det Kongelige Bibliotek, Gks $2772^{\circ}$ (s. XIII), where Ibn Ezra's tables (fols. 183v-190v) are preceded by a list of apogees for 1254 (fol. 183rb). ${ }^{101}$ The apogeal longitude of the Sun is here $2 ; 10^{\circ}$ higher than the familiar value for 1100 ( 2 s $28 ; 24^{\circ}$ vs. $2 s 26 ; 14^{\circ}$ ), which agrees perfectly with an increase of $0 ; 0,51^{\circ} / y$ over the 154 years from 1100 to 1254 , provided that sexagesimal seconds are ignored $\left(0 ; 0,51^{\circ} \times 154=2 ; 10,54^{\circ}\right)$. That the apogees are supposed to increase at this rate is confirmed by the canons attached to the Pisan tables in the same manuscript, which also allege that the solar apogee's position in 1248 was $2 \mathrm{~s} 28 ; 20^{\circ} \cdot{ }^{102}$ This is $2 ; 6^{\circ}$ higher than the value for 1100 , in good agreement with the fact that a precession of $0 ; 0,51^{\circ} / \mathrm{y}$ would produce an increase of $2 ; 5,48^{\circ}$ over 148 years.

100 I have seen the following copies: MSS Cambridge, University Library, Kk.1.1, fol. 171v; Cambridge, University Library, Mm.3.11, fol. 104v; Florence, Biblioteca Nazionale Centrale, Conv. soppr. J.V.6, fol. 83v; Oxford, Bodleian Library, Savile 22, fol. 76r, 79r. See also The Toledan Tables, ed. PEDERSEN, vol. III, p. 1226-1227. Note that MS Erfurt, Universitäts- und Forschungsbibliothek, Dep. Erf. CA $4^{\circ} 364$, fol. 102v, which is among the witnesses listed in this edition, shows a different set of apogeal values.

101 On the Tables of Pisa in this manuscript, see Fritz S. PeDERSEN, « Astronomical Tables for Pisa in Ms. København K.B., GkS 277, Fol », Renaessanceforum, 3 (2007), p. 1-16.

102 MS København, Det Kongelige Bibliotek, Gks $2772^{\circ}$, fol. 192vb: « A medio motu planete subtrahe augem eius, qui aux crescit omni anno 51 secundis. Anno autem domini $\mathrm{M}^{\circ}$.CC.XLVIII fuit aux solis 2 signa, 28 minuta, 20 secunda $»$. 
Shlomo Sela, Carlos Steel, C. Philipp E. Nothaft, David Juste \& Charles Burnett

\section{I.3.2. An ascension table for Winchester}

Computing the position of the solar apogee was one of the stepping stones towards the author's conclusion that the vernal equinox of the year 1067 occurred at 19;34h in the middle of the world (Arin), but at 14;50h at the meridian of Winchester. The concomitant ascendant degrees were, according to him, $25 ; 24^{\circ}$ and $279 ; 43^{\circ}$ (\$7.1:12). It is possible to infer from this information the assumed geographic latitude $(\varphi)$ of Winchester via the ascensional difference $(\gamma)$, using the relation

$$
\gamma=\arcsin (\tan \delta \times \tan \varphi) \cdot{ }^{103}
$$

The third variable in this relation is $\delta$, the declination of the relevant degree of ecliptic longitude $(\lambda)$, which is sensitive to the assumed value for the obliquity of the ecliptic $(\varepsilon)$, as per

$$
\delta=\arcsin (\sin \lambda \times \sin \varepsilon){ }^{104}
$$

To find the ascensional difference, the oblique ascension stated in our text must be subtracted from the corresponding right ascension, $\alpha$, which is most handily derived via the formula

$$
\alpha=\arctan (\cos \varepsilon \times \tan \lambda){ }^{105}
$$

Values for $\varepsilon$ known in twelfth-century Latin Europe include Ptolemy's $23 ; 51,20^{\circ}$, al-Battānì's $23 ; 35^{\circ}$, and the $23 ; 33,30^{\circ}$ assumed in the Toledan Tables. To these one may add a value of $23 ; 33,8^{\circ}$ first determined by Azarquiel and later also accepted by Abraham Ibn Ezra. ${ }^{106}$ Using these four values in turn, I obtain the four sets of parameters shown in Tab. 1 below. It lists the corresponding right ascension $(\alpha)$ and two variants of the inferred latitude, depending on whether one uses the oblique ascension of $312^{\circ}$ explicitly mentioned in $\$ 7.1: 12\left(\varphi_{1}\right)$ or the $312 ; 30^{\circ}$ that follow from the stated time $\left(\varphi_{2}\right)$. All values are rounded to the nearest minute.

103 José Chabás, Bernard R. Goldstein, A Survey of European Astronomical Tables in the Late Middle Ages, Brill, Leiden 2012 (Time, Astronomy, and Calendars: Texts and Studies, 2), p. 29.

104 Ibid., p. 22.

105 Ibid., p. 26.

106 Ibid., p. 23; BERNARD R. GoldSTEIn, The Astronomical Tables of Levi ben Gerson, Archon Books, Hamden (Conn.) 1974 (Transactions of The Connecticut Academy of Arts and Sciences, 45), p. 96; GEORGE SALIBA, «Critiques of Ptolemaic Astronomy in Islamic Spain », Al-Qanțara, 20 (1999), p. 3-25 (11). Tables for the solar equation and declination with a maximum declination of $23 ; 33,8^{\circ}$ appear among the Tables of Pisa in MSS København, Det Kongelige Bibliotek, Gks $2772^{\circ}$, fol. 183v-184r and Vatican City, Biblioteca Apostolica Vaticana, lat. 3119, fol. 10r-12v. Another instance among Latin tables is noted in The Toledan Tables, ed. PEDERSEN, vol. III, p. 967. 


\begin{tabular}{|l|l|l|l|}
\hline$\varepsilon$ & $\alpha$ & $\varphi_{1}$ & $\varphi_{2}$ \\
\hline $23 ; 51,20^{\circ}$ & $280 ; 36^{\circ}$ & $50 ; 10^{\circ}$ & $50 ; 34^{\circ}$ \\
\hline $23 ; 35^{\circ}$ & $280 ; 35^{\circ}$ & $50 ; 32^{\circ}$ & $50 ; 56^{\circ}$ \\
\hline $23 ; 33,30^{\circ}$ & $280 ; 35^{\circ}$ & $50 ; 34^{\circ}$ & $50 ; 58^{\circ}$ \\
\hline $23 ; 33,8^{\circ}$ & $280 ; 35^{\circ}$ & $50 ; 35^{\circ}$ & $50 ; 59^{\circ}$ \\
\hline
\end{tabular}

Tab. 1

All of these results remain within $1^{\circ}$ of the actual latitude of Winchester, which is measured at c.51; $4^{\circ}$. The closest approximation to this value in Tab. 1 is $50 ; 59^{\circ}$, as obtained using an oblique ascension of $312 ; 30^{\circ}$ and the obliquity value associated with Abraham Ibn Ezra $\left(23 ; 33,8^{\circ}\right)$. Depending on how accurate the author's calculations were, this probably means that he operated with a table for oblique ascensions cast for a latitude of $51^{\circ}$.

Later on, in \$7.1:22, the author mentions the ascendant degrees at Arin and Winchester for the lunisolar opposition of 26 August 1067, yet this time no information as to the corresponding time or ascension is provided. Also, the manuscripts confront us with two divergent sets of values. The Latin text in MS V gives the ascendant at Winchester as $198 ; 7^{\circ}$ and the ascendant at Arin as $276 ; 5^{\circ}$, whereas the Middle English translation MS $L$ lowers the first value to $190 ; 7^{\circ}$ and raises the second to $280 ; 5^{\circ} .{ }^{107}$ The latter reading seems to be supported by the third of the three horoscopes included in $V$ (fol. 58r), which has the first house begin at $10^{\circ}$ Capricorn.

An attempt to clarify the issue can be made by extracting the implied time of true opposition from the data at hand. From \$7.1:21, it follows that the true solar longitude at this point in time was $338 ; 59,1^{\circ}-180^{\circ}=158 ; 59,1^{\circ}\left(158 ; 59,2^{\circ}\right.$ according to MS $L$ ). The difference in right ascension between this value and $276 ; 5^{\circ}$ (the ascendant at Arin in $V$ ) is $116 ; 1,59^{\circ}$ or $7 ; 44,5 \mathrm{~h}$, provided the obliquity of the ecliptic is taken to be $23 ; 33,8^{\circ}$. Applied to an equinoctial sunrise at 6 a.m., this yields a time of 01:44:05 p.m. For an ascendant of $280 ; 5^{\circ}$ (the value in $L$ ), this result would have to be raised to 02:01:31 p.m. Subtracting the time difference of $4 ; 44 \mathrm{~h}$ for the distance Winchester-Arin (\$7.1:4) gives us 09:00:05 a.m. or 09:17:31 a.m. as the time of true syzygy at the meridian of Winchester.

If the latitude of Winchester is taken to be $51^{\circ}$ (and $\left.\varepsilon=23 ; 33,8^{\circ}\right)$, the difference in oblique ascension between $158 ; 59,1^{\circ}$ and $198 ; 7^{\circ}$ (the ascendant in $V$ ) is $55 ; 17,34^{\circ}$ or $3 ; 41,10 \mathrm{~h}$. Adding this value to the sunrise time corresponding to $\lambda=158 ; 59,1^{\circ}$, which is 05:18:48 a.m., we obtain a result of 08:59:58 a.m. ${ }^{108}$ Using the ascendant in $L$, we instead find a difference in oblique ascension of $43 ; 58,34^{\circ}$ or $2 ; 55,54 \mathrm{~h}$,

107 North misinterpreted the ascendant at Arin as referring to the degree at lower mid-heaven (imum medium coelum). See NORTH, « Winchester 1067 », p. 134.

108 The formula to derive the length of daylight from the oblique ascension is explained in CHABÁS, GolDSTEIn, A Survey, p. 31. 
Shlomo Sela, Carlos Steel, C. Philipp E. Nothaft, David Juste \& Charles Burnett

pointing to a time of 08:14:42 a.m. The fact that the times implied by the acendants in $V$ are only 7 seconds apart, whereas those in $L$ differ by more than an hour, may be taken as a fairly strong sign that the readings in $V$ are authentic.

\section{I.3.3. Planetary equations}

Another conclusion we can draw from the author's detailed calculation of the vernal equinox of 1067 concerns the method by which he derived the solar equation as a function of the Sun's apogeal longitude. In \$7.1:8-9 the solar equation at equinox is expressly given as $+1 ; 58,48^{\circ}$ and then subtracted from $0^{\circ}=360^{\circ}$ to infer the corresponding mean longitude of $358 ; 1,12^{\circ}$. Here it is worth knowing that the surviving manuscripts of the Tables of Pisa transmit two different tables for the solar equation. In MS Paris, Bibliothèque nationale de France, lat. 16207, fol. $21 \mathrm{r}-\mathrm{v}$ (s. XIII), we encounter the common type that also accompanies the Toledan Tables, with a maximum equation of $\pm 1 ; 59,10^{\circ} .{ }^{109}$ By contrast, in MS København, Det Kongelige Bibliotek, Gks $2772^{\circ}$, fols. 183v-184r, and twice in MS Vatican City, Biblioteca Apostolica Vaticana, lat. 3119, fols. 2v, 4r-v, 10r-12v (s. XIII), we have renditions of a table whose maximum equation is $\pm 1 ; 59,8^{\circ}$ for an anomaly of $90^{\circ}-$ $93^{\circ}$. In one of these renditions, MS Vat. lat. 3119 , fols. $10 \mathrm{r}-12 \mathrm{v}$, the table includes a column for the solar declination whose maximum is Ibn Ezra's 23;33,8 $8^{\circ}$. For a solar equation of $+1 ; 58,48^{\circ}$ linear interpolation on the basis of these tables suggests an anomaly of $272 ; 55^{\circ}$, whereas the standard "Toledan » equation tables yield $272 ; 12^{\circ}$. Based on the apogeal longitude in 1067 (\$7.1:7), the anomaly our author used to enter his equation tables should have been $358 ; 1,12^{\circ}-85 ; 46^{\circ}=272 ; 15,12^{\circ}$, which makes it likely that the tables he relied on were computed for a maximum equation of $\pm 1 ; 59,10^{\circ}$.

Other than the case just presented, there are a few more instances in the text where the author cites both the mean and the true longitude of a given planet, allowing us to draw certain conclusions about his method of calculating the corresponding equation. In \$7.1:14 we are told that at the moment of the JupiterSaturn conjunction of 1067 the mean Sun was at $168 ; 54,41^{\circ}$, whereas the true Sun was at $166 ; 57^{\circ}$. The implied equation is $166 ; 57^{\circ}-168 ; 54,41^{\circ}=-1 ; 57,41^{\circ}$, which according to the standard equation table would result from an anomaly of $82 ; 55^{\circ}$. For the alternative table with maximum equation $\pm 1 ; 59,8^{\circ}$ the corresponding anomaly would be $82 ; 50^{\circ}$. The anomaly the author should have used based on his apogeal position for 1067 is $168 ; 54,41^{\circ}-85 ; 46^{\circ}=83 ; 8,41^{\circ}$. Once again, the standard equation table gives a result that is slightly closer to the one expected.

For Saturn and Jupiter, whose joint true position was $168 ; 51^{\circ}\left(168 ; 52^{\circ}\right.$ in MS L), we are given mean longitudes of $162 ; 23,17^{\circ}$ and $168 ; 22,46^{\circ}$, respectively (\$7.1:14).

109 For an edition of the standard set of equation tables for all seven planets, see The Toledan Tables, ed. Pedersen, vol. IV, p. 1245-1306. 
Let us begin with Saturn, for which the implied total equation is $168 ; 51^{\circ}$ $162 ; 23,17^{\circ}=+6 ; 27,43^{\circ}$. The position of the apogee can be derived from the aforementioned list for 1100 , where it is $250 ; 10^{\circ}$. Following the author's modus operandi for the Sun, we subtract 0;28 to obtain the apogee for $1067: 250 ; 10^{\circ}-0 ; 28^{\circ}$ $=249 ; 32^{\circ}$. We accordingly find the mean centre $(\overline{\mathrm{k}})$ to be $162 ; 23,17^{\circ}-249 ; 32^{\circ}+360^{\circ}$ $=272 ; 51,17^{\circ}$. According to the standard equation table, the corresponding equation of centre is $6 ; 29 ; 9,43^{\circ}$. Based on the numbers provided, the mean anomaly $(\bar{\alpha})$ should have been $168 ; 54,41^{\circ}-162 ; 23,17^{\circ}=6 ; 31,24^{\circ}$. For the true anomaly $(\alpha)$, we accordingly find $6 ; 31,24^{\circ}-6 ; 29,9,43^{\circ}=0 ; 2,14,17^{\circ}$. Again following the standard tables, the equation of anomaly will be $0 ; 13,25,42^{\circ}$, in which case the minutes of proportion reduce to 0 . The total equation will hence be $6 ; 29,9,43^{\circ}+0 ; 0,13,25,42^{\circ}=$ $6 ; 29,23,42^{\circ}$ rather than $6 ; 27,43^{\circ}$.

In the case of Jupiter, the total equation implied in the text is $168 ; 51^{\circ}-$ $168 ; 22,46^{\circ}=0 ; 28,14^{\circ}$. The apogeal position was $172 ; 40^{\circ}-0 ; 28^{\circ}=172 ; 12^{\circ}$, hence $\bar{\kappa}=$ $168 ; 22,46^{\circ}-172 ; 12^{\circ}+360^{\circ}=356 ; 10,46^{\circ}$. The equation tables for Jupiter show a corresponding equation of centre of $0 ; 22,55,24^{\circ}$. For $\bar{\alpha}$ we find $168 ; 54,41^{\circ}$ $168 ; 22,46^{\circ}=0 ; 31,55^{\circ}$, such that $\alpha=0 ; 31,55^{\circ}+0 ; 22,55,24^{\circ}=0 ; 54,50,24^{\circ}$, with an equation of anomaly of $0 ; 9,8,24^{\circ}$. Minutes or proportion are once again negligible. The total equation is here $0 ; 22,55,24^{\circ}+0 ; 9,8,24^{\circ}=0 ; 32,3,48^{\circ}$ compared to the $0 ; 28,14^{\circ}$ implied in our text.

In \$7.1:20-22, the author supplies the positions of the Sun and Moon at the true opposition preceding the Jupiter-Saturn conjunction, yet the numbers fail to add up. The implied true solar longitude is $161 ; 1,26^{\circ}-158 ; 59,1^{\circ}=2 ; 2,25^{\circ}$ behind the stated position of the mean Sun, yet a solar equation of $-2 ; 2,25^{\circ}$ is plainly incompatible with either type of equation table. If we take at face value the mean longitude, we obtain an anomaly of $161 ; 1,26^{\circ}-85 ; 46^{\circ}=75,15,26^{\circ}$, which gives an equation of $-1 ; 54 ; 25^{\circ}$ if the standard table is used, but $-1 ; 54,22^{\circ}$ if one opts for the alternative noted above.

For the Moon, the same passage offers a mean longitude of $337 ; 50,24^{\circ}$ and an implied lunar equation of $338 ; 59,1^{\circ}-337 ; 50,24^{\circ}=1,8,37^{\circ}$. The two variables needed to calculate the lunar equation are the mean anomaly $(\bar{\alpha})$ and the double elongation between the mean Moon and mean Sun $(2 \eta)$. For $\eta$, the recorded data give us $337 ; 50,24^{\circ}-161 ; 1,26^{\circ}=176 ; 48,58^{\circ}$, hence $2 \eta=353 ; 37,56^{\circ}$, for which the standard tables yield an equation of centre of $0 ; 57^{\circ}$. For $\bar{\alpha}=212 ; 39,52^{\circ}$, as stated in $\$ 1.20$, we find $\alpha=212 ; 39,52^{\circ}-0 ; 57^{\circ}=211 ; 42,52^{\circ}$. The minutes of proportion are 0 , which means that we can confine ourselves to the equation of anomaly, which for $\alpha=211 ; 42,52^{\circ}$ is $+2 ; 51,16^{\circ}$. The true longitude of the Moon should accordingly be $337 ; 50,24^{\circ}+2 ; 51,16^{\circ}=340,41,40^{\circ}$ as opposed to the stated $338 ; 59,1^{\circ}$. It may be that the mean anomaly used for the calculation was lower than the $212 ; 39,52^{\circ}$ mentioned in our text, which comes with the strange qualifier in media die illa (\$7.1:20). That the intended time of true opposition was not midday is clear from 
Shlomo Sela, Carlos Steel, C. Philipp E. Nothaft, David Juste \& Charles Burnett

the ascendant degrees in \$7.1:22, which converge on a time close to 9 a.m. (see above).

\section{I.3.4. Mean longitudes}

As seen from the foregoing, the planetary equations implicit in our text mostly fail to match the result one can derive by computation from the stated mean longitudes and known apogeal positions. One noteworthy exception is the equation of the Sun in $\$ 7.1: 8$, which at $+1 ; 58,48^{\circ}$ is almost exactly what the standard tables would lead one to expect. We are not so lucky with the mean solar longitudes recorded in the text, which cannot be re-calculated on the plausible assumption that the Tables of Winchester used by the author were the Tables of Pisa with the meridian shifted $14^{\circ}$ westward. For the mean Sun at the beginning of 1 March 1067, the Winchester tables are claimed to yield a mean motion of $11 \mathrm{~s} 14 ; 46,40^{\circ}$ (\$7.1:5). Tab. 2 below compares this value with the results obtainable from the Tables of Pisa and Toledan Tables, ${ }^{110}$ using the implied difference of meridians as a measure of their mutual discrepancy.

\begin{tabular}{|l|l|l|l|}
\hline & Text & Pisa & Toledo \\
\hline 1 Mar 1067 & $344 ; 46,40^{\circ}$ & $344 ; 32,12^{\circ}$ & $344 ; 33,12^{\circ}$ \\
\hline meridian & $0^{\circ}$ & $+88 ; 4^{\circ}$ & $+82^{\circ}$ \\
\hline
\end{tabular}

Tab. 2

That these massive disparities are the result of some transmission error seems altogether likely if we consider that the text's mean longitude at epoch $1 \mathrm{March}$ 1067 stands in no adequate relation to the stated time of the vernal equinox (VE), which is given as 14 March, 19:34h, for the meridian of Arin and as 14 March, 14:50h, for Winchester (\$7.1:12). From the stated mean longitude at VE of $358 ; 1,12^{\circ}$ (\$7.1:9) one can derive a difference between 1 March 1067 and VE of 358;1,12 ${ }^{\circ}$ $344 ; 46,40^{\circ}=13 ; 14,32^{\circ}$. Our author performs this calculation for the meridian of Arin, subtracting not $344 ; 46,40^{\circ}$, but $344 ; 34^{\circ}$ ( $\left.\$ 7.1: 5\right)$. The assumption here is that the longitude difference between Winchester and Arin $\left(71^{\circ}\right.$ or $\left.4 ; 44 \mathrm{~h}\right)$ makes for a decrease in mean solar longitudes of $0 ; 11 ; 40^{\circ}$ (\$7.1:4). This is roughly speaking correct (the precise value based on the Tables of Pisa would be $11 ; 39,48,33 \ldots{ }^{\circ}$ ), yet the subtraction performed in the text involves an error. The mean longitude at Arin should be $344 ; 46,40^{\circ}-0 ; 11 ; 40^{\circ}=344 ; 35^{\circ}$ instead of $344 ; 34^{\circ}$ and the difference between 1 March and VE should be $13 ; 26,12^{\circ}$ instead of $13 ; 27,12^{\circ}$.

110 For the Tables of Pisa, I have used the copy in MS Vatican City, Biblioteca Apostolica Vaticana, lat. 3119 , fol. $1 \mathrm{v}-42 \mathrm{r}$, comparing the results with those produced by Raymond Mercier's program devplo (<http://www.raymondm.co.uk/>). For the Toledan Tables I have used devplo directly. 
Another error was committed in deriving the corresponding time interval. According to the Tables of Pisa, the solar mean motion in 13 days is $13 \times$ $0 ; 59,8,19,42,45 \ldots{ }^{\circ} / \mathrm{d}=12 ; 48,48,16 \ldots{ }^{\circ}$, which would leave a remainder of $13 ; 27,12^{\circ}-$ $12 ; 48,48^{\circ}=0 ; 38,24^{\circ}$, the equivalent of $15 ; 35,1 \mathrm{~h}$. The text has $0 ; 34,24^{\circ}$, with the variant in aliis $0 ; 48 ; 13^{\circ}$ noted in the left margin (\$7.1:11). For the former value, the time equivalent would be $13 ; 57,37 \mathrm{~h}$, for the latter it is $19 ; 34 \mathrm{~h}$, the time of VE actual stated in the text (\$1.12). The chasm between these two timestamps gives further weight to suspicions about the garbled nature of the text before us. There is indeed no way the stated mean longitude for 1 March $1067\left(344 ; 46,40^{\circ}\right)$ could have led to a VE at 19:34h $-4: 44 \mathrm{~h}=14: 50 \mathrm{~h}$. Much rather, the mean longitude at epoch should have been $358 ; 1,12^{\circ}$ (assumed mean longitude at VE) - 13;25,21 (solar mean motion in $13 \mathrm{~d} 14 ; 50 \mathrm{~h})=344,35,51^{\circ}$. As seen from Tab. 3 , however, substituting this value would do little to strengthen North's position according to which the author used the Toledan Tables, which still differ by the equivalent of $c .16^{\circ}$ in longitude. That anybody would have consciously placed Winchester $16^{\circ}$ further west than Toledo is scarcely plausible. It should therefore come as no surprise that North's claim according to which the Toledan Table make the Sun enter the sign of Aries at the same time as our text does not withstand independent verification. ${ }^{111}$ For the Tables of Pisa, the implied meridian difference reduces to $22 ; 14^{\circ}$, which still exceeds the expected $14^{\circ}$ by a troublingly wide margin.

\begin{tabular}{|l|l|l|l|}
\hline & Text & Pisa & Toledo \\
\hline 1 Mar 1067 & $344 ; 35,51^{\circ}$ & $344 ; 32,12^{\circ}$ & $344 ; 33,12^{\circ}$ \\
\hline meridian & $0^{\circ}$ & $+22 ; 14^{\circ}$ & $+16 ; 10^{\circ}$ \\
\hline
\end{tabular}

Tab. 3

The mean longitudes of the Sun, Jupiter, and Saturn at the conjunction of the two outermost planets are difficult to assess for the simple reason that the text fails to specify the time at which this conjunction took place. All we are given is a date, 6 September, which was 24 Shawwāl in year 459 of the Arabic calendar (\$7.1:17-18). It is implied that this date saw the Sun pass through the degrees of both Jupiter and Saturn, but that the actual conjunction between the two planets happened two days earlier, on 4 September. Using the Tables of Pisa one indeed finds the mean solar longitude of $168 ; 54,41^{\circ}$ accompanying the said conjunction (\$7.1:14) on 4 September at c.1;26h after noon. If the author made his calculation for the beginning of the astronomical day, i.e., for noon, this result would point to a meridian difference of $c .21 ; 30^{\circ}$, quite close to the $22 ; 14^{\circ}$ found in the previous example. What is even more striking, however, is the fact that the Tables of Pisa, once they are adjusted to this time and meridian, yield mean longitudes of Jupiter

111 See the table in NORTH, «Winchester 1067 », p. 134, which gives the Toledan solar longitude as $00 ; 00^{\circ}$. According to devplo the Toledan true Sun on 14 March, $14: 50 \mathrm{~h}$ was $359 ; 57,1^{\circ}$. 
Shlomo Sela, Carlos Steel, C. Philipp E. Nothaft, David Juste \& Charles Burnett

and Saturn relatively close to those mentioned in the text (\$7.1:14). ${ }^{112}$ As may be seen from Tab. 4, the deviations are in the range of a few seconds of arc, whereas the results produced by the Toledan Tables differ by several minutes.

\begin{tabular}{|l|l|l|l|}
\hline \multicolumn{4}{|c|}{ 4 September 1067, 0;0h } \\
\hline & Text & $\begin{array}{l}\text { Pisa } \\
\left(+21 ; 30^{\circ}\right)\end{array}$ & $\begin{array}{l}\text { Toledo } \\
\left(+15 ; 40^{\circ}\right)\end{array}$ \\
\hline Sun & $168 ; 54,41^{\circ}$ & $168 ; 54,41^{\circ}$ & $168 ; 54,41^{\circ}$ \\
\hline Jupiter & $168 ; 22,46^{\circ}$ & $168 ; 23,10^{\circ}$ & $168 ; 16,35^{\circ}$ \\
\hline Saturn & $162 ; 23,17^{\circ}$ & $162 ; 23,25^{\circ}$ & $162 ; 30,27^{\circ}$ \\
\hline \multicolumn{4}{|c|}{ Tab. 4}
\end{tabular}

\section{I.3.5. Conclusion}

The overall picture emerging from the examples discussed above is that North's hypothesis, according to which the calculations in $\$ 7$ depend on the Toledan Tables, does not hold up in light of the data supplied by MS V. At the same time, however, it has not been possible to recalculate the mean longitudes and equations in this text in a way that would fully bear out the alternative proposition according to which the lost Tables of Winchester were adapted from Abraham Ibn Ezra's Tables of Pisa. This alternative nevertheless retains a strong degree of verisimilitude, especially considering that the author refers to a set of mean motion tables with the same calendrical structure. We have also noted a striking degree of convergence between the Tables of Pisa and the text's simultaneous mean longitudes of the Jupiter, Saturn, and the Sun at the conjunction of September 1067. Both in this example and that of the preceding vernal equinox, the data at hand would require the longitude adjustment to the Tables of Pisa to have exceeded the $14^{\circ}$ suggested by the text's placement of Winchester at $19^{\circ}$ from the western prime meridian (compared to Pisa's $33^{\circ}$ ). It remains uncertain at this point whether such discrepancies are entirely due to textual corruptions, which have no doubt affected the numbers in both $V$ and $L$, or whether we might be looking at the result of actual changes to the radices or parameters of the Pisan tables. The most likely originator of any such changes remains Ibn Ezra himself, whose travels across Western Europe gave him a strong incentive to refashion his astronomical tables as he moved from one place to another.

112 I have based these calculations on the values displayed in MSS Paris, Bibliothèque nationale de France, lat. 16208, fol. $4 \mathrm{r}$ and Vatican City, Biblioteca Apostolica Vaticana, lat. 3119, fol. 21v-22r, $25 \mathrm{v}-26 \mathrm{r}$. According to devplo, the mean longitudes of Saturn and Jupiter were $162 ; 23,28^{\circ}$ and $168 ; 24,11^{\circ}$, respectively. 


\section{I.4. The Horoscopes of the Great Conjunction of 1067 \\ (David Juste)}

Part I, §7.1 is devoted to the calculation of the horoscopes of the great conjunction of 1067 for Winchester. This retrospective conjunction was probably chosen because it coincides with the Norman Conquest of 1066, and we may surmise that Abraham Ibn Ezra, who is one of the earliest accomplished astrologers attested in England, was asked to cast these horoscopes in order to shed light on some aspect of British history. The choice of Winchester, a major political centre of England, also makes perfect sense in this context.

Two horoscopes are taken into account, namely the horoscope of the entry of the Sun into Aries in 1067 (\$7.1:2-13) and the horoscope of the syzygy preceding the great conjunction (\$7.1:14-22). Each of these horoscopes is cast for two places, i.e. for the centre of the world (said to be Arin, §7.1:3) and for Winchester, so that four horoscopes are actually discussed. The idea of casting horoscopes of great conjunctions for the centre of the world is in tune with Abraham Ibn Ezra's teaching ${ }^{113}$ and is also found in the second treatise attributed to al-Kindī. ${ }^{114}$ Likewise, casting horoscopes for both the entry of the Sun into Aries and the syzygy preceding the great conjunction is what seems to be advocated in the present tripartite text (Part I, §3.3:3-4; Part II, \$2:5-8; Part III, §2:2-3). It should be noted, however, that this stands in sharp contradiction to Abraham Ibn Ezra, who resorts to syzygy horoscopes only and strongly rejects the horoscope of the Sun's entry into Aries. ${ }^{115}$

\section{I.4.1. Horoscope 1}

Horoscope 1 is the horoscope of the entry of the Sun into Aries in 1067 at the centre of the world. The text says that this occurred on 14 March at 19:34pm [=15 March at 7:34am] and that the ascendant was then at $25^{\circ} 24^{\prime}$ Aries (\$7.1:2 and 12). All houses are located at $25^{\circ} 24^{\prime}$ (equal houses). The planetary positions match those given in the text (\$7.1:13).

113 'Olam II, ed. SELA, §5.3, p. 159; also in our Part I, §3.3:3.

114 Part III, \$2:2.

115 'Olam II, ed. SELA, \$5, p. 159, where three horoscopes, of varying - weighted - importance, are considered: that of the syzygy preceding the entry of the Sun into Aries (50\%); that of the syzygy preceding the entry of the Sun into the cardine in which the conjunction takes place, i.e., Cancer, Libra or Capricorn (33\%); and that of the syzygy preceding the great conjunction itself (17\%). The same three horoscopes are considered in 'Olam I, ed. SELA, \$20, p. 65. Ibn Ezra rejects the horoscope of the Sun's entry into Aries because, as he explains at great length, its exact time, i.e. its ascendant, cannot be known. See 'Olam I, ed. SeLA, §§12-18, p. 59-65. These discussions stem from the fact that the exact time of the great conjunction itself cannot be determined, on account of the slowness of Jupiter and Saturn, a point stressed in 'Olam I, ed. SELA, \$11, p. 59, and also in our Part I, §3.3:1-2. 
Shlomo Sela, Carlos Steel, C. Philipp E. Nothaft, David Juste \& Charles Burnett

The position of Venus is given as $7^{\circ} 15^{\prime}$ Aries both in the figure and in the text ("Veneris 0.7.15 »; but $17^{\circ} 16^{\prime}$ Aries in the English version: "Venus 17.16 Aries »), but this is evidently a mistake for $7^{\circ} 15^{\prime}$ Taurus (Venus was actually at $7^{\circ}-8^{\circ}$ Taurus on 15 March 1067). Such a gross mistake in calculation being unlikely, we must rather suppose that the original text had Venus at «1.7.15» or « 1.7.16» (i.e. $7^{\circ} 15^{\prime}$ or $7^{\circ} 16^{\prime}$ Taurus), which would have become "Venus 17.16 Aries» in the English and « 0.7.15 » in the Latin. The Latin text was corrected at that place, with « 0 » added over an erased value (see note ad. loc). The fact that Venus at $7^{\circ} 15^{\prime}$ Aries is shown below Mars at $14^{\circ} 26^{\prime}$ Aries in the figure also suggests that Venus was meant to be in Taurus.

Jupiter is wrongly shown in the fifth house instead of the sixth. Note that the first copying mistake mentioned below does not affect Jupiter's house position. There is a slight discrepancy for the Head of the Dragon, located at $11^{\circ} 40^{\prime}$ Virgo in the figure and at $11^{\circ} 30^{\prime} 14^{\prime \prime}$ in the text (11 in the English version).

Three copying mistakes have been corrected in the figure: (1) Jupiter is located at $21^{\circ}$ Virgo ("Iupiter 21 Virginis »), but this is an obvious misreading for « Iupiter 2.1 Virginis » as given in the text (« Iupiter 5.2.1»). (2) The cusp of the third house is located at $25^{\circ} 34^{\prime}$ (Gemini), instead of $25^{\circ} 24^{\prime}$. (3) The cusp of the twelfth house is located at $24^{\circ} 28^{\prime}$ (Aquarius), instead of $25^{\circ} 24^{\prime}$.

\section{I.4.2. Horoscope 2}

Horoscope 2 is the same horoscope cast for Winchester. The longitude of Winchester is given in the text (\$7.1:4), from which the author infers that the time of the present horoscope was 14:50pm [=15 March at 2:50am] and that the ascendant was then at $9^{\circ} 43^{\prime}$ Capricorn (\$7.1:12), a value which has been rounded up to $10^{\circ}$ in the figure. The horoscope provides only the positions of the houses, which are here unequal in length. This is the essential difference with Horoscope 1 and this difference agrees with the double house system advocated by Ibn Ezra in several of his works. ${ }^{116}$ It is unclear why the planets are omitted. The planets would have the same longitudes as in Horoscope 1, but they would appear in different houses, something which would significantly affect the astrological judgement. A copying mistake has been corrected in the figure, namely the cusp

116 See Țéamim I, ed. SELA, §10.2, p. 97 (and comm. p. 174-175); Mishpetei ha-mazzalot, ed. SELA, §§13 and 76, p. 499-501 and 555 (and comm. p. 581-582 and 632). See also SHLomo Sela, Abraham Ibn Ezra on Elections, Interrogations, and Medical Astrology. A Parallel Hebrew-English Critical Edition of the 'Book of Elections' (3 Versions), the 'Book of Interrogations' (3 Versions), and the 'Book of the Luminaries', Brill, Leiden - Boston 2011 (Études sur le judaïsme médiéval, 50), p. 132-133; ID., Abraham Ibn Ezra on Nativities and Continuous Horoscopy. A Parallel Hebrew-English Critical Edition of the 'Book of Nativities' and the 'Book of Revolution', Leiden, 2013 (Études sur le judaïsme médiéval, 59), p. 404 and 406-407. 
of the eleventh house located at $64^{\circ}$ Sagittarius instead of $4^{\circ}$ Sagittarius (cf. the fifth house at $4^{\circ}$ Gemini).

\section{I.4.3. Horoscope 3}

Horoscope 3 is the horoscope of the syzygy (opposition) preceding the great conjunction at the centre of the world. The great conjunction is said to have occurred on 6 September 1067 (\$7.1:17) and the preceding syzygy on 26 August (§7.1:20). Again, the planetary positions are missing (but they are provided in the text, §7.1:19) and only the positions of the houses are given, all at $10^{\circ}$ of each sign (equal houses) starting with the ascendant rounded up to $10^{\circ}$ Capricorn $\left(6^{\circ} 05^{\prime}\right.$ Capricorn in the text (\$7.1:22), but the English version has $10^{\circ} 05^{\prime}$ Capricorn, a variant which suggests that the English version does not derive from our MS V).

One would have expected a fourth horoscope for the syzygy preceding the great conjunction in Winchester, for which the ascendant is provided in the text at $18^{\circ} 07^{\prime}$ Libra (\$7.1:22).

\section{I.5. Identifying the Translators (Shlomo Sela)}

As said above, Part I incorporates a hitherto unknown Latin translation of Ibn Ezra's 'Olam III but we are not informed about the identity of the Latin translator. Part II is the smallest component of our tripartite text (900 out of 8,400 words). The Latin translator informs us in the incipit that it includes a treatise on the judgements of the world-years composed by Ya'qūb, the son of Isaac al-Kindī, previously translated from Arabic into Hebrew. ${ }^{117}$ The identity of the Latin translator or of the translator of the Arabic into Hebrew source text, though, is not revealed. Part III covers almost half of the tripartite text (3,600 out of 8,400 words). From a combined scrutiny of its incipit and colophon we learn that it includes the Latin translation carried out by Henry Bate in 1278 in Mechelen of another treatise by Ya'qüb, entitled Book on the judgments of the revolutions of the world-years, and that the Latin translation was also carried on the basis of an Arabic into Hebrew translation. ${ }^{118}$ We are left in the dark, though, regarding the identity of the translator of the Arabic into Hebrew source text. Who carried out the Latin translations of 'Olam III and of the first Kindian treatise, and the Arabic into Hebrew translations of the first and second Kindian treatises?

117 See Part II $\$ 1: 1$

118 See Part III §1:1-4 and colophon. 
Shlomo Sela, Carlos Steel, C. Philipp E. Nothaft, David Juste \& Charles Burnett

\section{I.5.1.}

That Henry Bate, who is credited with being the Latin translator of the second Kindian treatise, was also the Latin translator of 'Olam III and of the first Kindian treatise, emerges from the fact that all three parts of our text bear the hallmark of Bate as translator of Hebrew texts: double Latin translations to single underlying Hebrew terms. You will not find such double translations with the same frequency in the Latin translations of Ibn Ezra's astrological treatises by Pietro d'Abano, Pierre de Limoges, Arnoul de Quincampoix, and anonymous translators as you may find in all of Bate's translations of Ibn Ezra's works. ${ }^{119}$ This most distinctive feature is also conspicuous in Part I ${ }^{120}$ Part II ${ }^{121}$ and Part III. ${ }^{122}$ Moreover, four among the seven doublets in Part I have their counterpart in Bate's other translations of Ibn Ezra's astrological writings. ${ }^{123}$ A further feature that betrays Bate's hand in Part I, in the title of the second table of lunar mansions, is the use of philosophi to denote astrologers/astronomers. ${ }^{124}$ For additional information showing that Bate was the translator of Part I, see below, p. 238.

As far as we know Henry Bate was not conversant with Hebrew. How then could the Hebrew into Latin translations of 'Olam III and the two Kindian treatises be carried out? It is reasonable to assume that Bate carried out these translations $\grave{a}$

119 I hope to expand on this point in a paper in the near future.

120 In Part I, see: « in inferiori parte orbis ecentrici sive in opposito augis » (\$1.1:4); " partes sive divisiones » (\$1.1:7); « actio vel operatio » $(\$ 2.5: 7)$; « in loco linee equalis sive medii mundi » (\$3.3:3); «carnifex seu decollator » (\$5.2:22); «trusio sive cornus » (\$5.3:1); « numerus vel quantitas » (\$6.3:5).

121 In Part II, see: « universalia seu communia » (\$2:1); « partes terre seu regiones » (\$2:4); « signum seu figura » (\$2:5); « terra seu regio » (\$2:9); « principes magni aut magnates » (\$3:1); « milites et belligeres » (\$3:1); «Christiani vel non circumcisi » $(\$ 3: 2)$; « terram Iudeorum, id est Iudea » (\$3:3); «terra Dalhenam, idest Indorum » (\$3:2); «terra Cumanorum, idest Arabum » (\$3:5); « Philistin, idest Palestina » (\$4:2); « Christiani idest non circumcisi » (\$4:5); « terra Alterath idest terra Turcorum » (\$4:6); « Metarmonia idest Macedonia » (\$4:11); « Maheraen idest Egiptus » (\$4:11); « Baldac, idest Baudas » (\$5:1).

122 In Part III, see: « revolutio anni mundi vel orbis » (\$2:2); « duci vel dirigi » (\$3:1); « dominus sive princeps » (\$3:5); « Romani, idest Christiani » (\$3:7); « antiquus vel precedens » (§5:5); « generale sive commune » (\$10:2); « in signo aqueo vel in signo super aquam significante »(\$11:2); «temperate sive mediocres» (\$13:3); «dispositio sive figura celi stellati » (\$13:4); « lux sive splendor » (\$14:11); « radius sive splendor» (\$15:6); «detrimentum seu exitium» $(\$ 20: 2)$; «mundicies aeris sive serenitats (\$21:11); « ducas vel dirigas » (\$24:2).

123 See MS Leipzig, UB 1466, fol. 48rb (Bate's translation of Mishpetei ha-Mazzalot: «numerus seu quantitas »); fol. 53vb (Bate's translation of Téamim II: « actio vel operatio »); fol. 68va (Bate's translation of Téamim I: " partes seu divisiones »); fol. 15rb (Bate's translation of Reshit Hokhmah: « in opposito augis hoc est in circulo ecentrico »).

124 See Part I, \$5.3:2 and below note 155; cf. Bate’s Nativitas, in SteEL et al. (eds.), The Astrological Autobiography, p. 130, 1. 91-92, 96; p. 137, 1. 285; p. 138, 1. 328; p. 140, 1.373-374, et passim. 
quatre mains: Hagin le Juif, Bate's neighbor in Mechelen, ${ }^{125}$ translated from Hebrew into French, and Bate rendered then from French into Latin. We may assume that Henry Bate found the Hebrew text of 'Olam III as well as the Hebrew translations of the two Kindian treatises in a Hebrew codex, and decided to translate them into Latin because at this stage of his career he was interested in world astrology and weather forecasting. Moreover, one is tempted to assume that Henry Bate translated these three works together because he considered 'Olam III to be useful for the understanding of some of the topics addressed in the two Kindian treatises, a sort of introduction to them. This is supported by the following table of correspondences of topics addressed in the three parts of our text:

\begin{tabular}{|l|l|l|l|}
\hline \multicolumn{1}{|c|}{ Topic } & \multicolumn{1}{c|}{ Part I } & \multicolumn{1}{c|}{ Part II } & \multicolumn{1}{c|}{ Part III } \\
\hline $\begin{array}{l}\text { conjunctions of Saturn } \\
\text { and Jupiter }\end{array}$ & $\S 3.2: 1-6 ; \S 3.3: 1-2$ & $\S 2: 1-11$ & $\S 2: 1-2$ \\
\hline $\begin{array}{l}\text { revolution of the world- } \\
\text { year }\end{array}$ & $\S 3.3: 3-5$ & & $\S 2: 3$ \\
\hline nature of planets & $\begin{array}{l}\S 2.1: 1-3 \text { through } \\
\S 2.5: 1-9\end{array}$ & & $\begin{array}{l}\S 2: 2 ; \S 17: 1 ; \S 18: 6 ; \\
\S 22: 4 ; \S 26: 2\end{array}$ \\
\hline nature of the signs & $\S 2.6: 1-4$ & & $\S 2: 3$ \\
\hline lunar mansions & whole chapter 5 & & $\S 10: 1 ; \S 13: 1-4 ;$ \\
\hline humid lunar mansions & $\begin{array}{l}\S 5.3: 4,12,16,17, \\
22,27\end{array}$ & & $\S 13: 1-2$ \\
\hline aspects & $\S 2.6: 2$ & & $\S 14: 1-12$ \\
\hline
\end{tabular}

Since the colophon of Part III informs that the second Kindian treatise was translated by Henry Bate in 1278, it is plausible that this year is also the date of the translation of the first Kindian treatise as well as that of the Latin translation of 'Olam III. If true, this assumption makes the Latin translation of 'Olam III Bate's first translation of Ibn Ezra's astrological writings. This choice of translating three treatises addressing world astrology and weather forecasting in 1278 fits well with the fact that Bate decided to translate Ibn Ezra's 'Olam I in 1281.

\section{I.5.2.}

As said above, Bate's Latin translations of both Kindian treatises were carried out on the basis of Arabic into Hebrew translations. Was Abraham Ibn Ezra their Arabic into Hebrew translator? ${ }^{126}$

125 For the connection between Henry Bate and Hagin le Juif, see SHLOMO SELA, « The Impact of Hagin Le Juif's French Translations on Subsequent Latin Translations of Abraham Ibn Ezra's Astrological Writings ", Jewish Quarterly Review (forthcoming).

126 This possibility was suggested by David Juste in STEel et al. (eds.) The Astrological Autobiography, p. 49. 
Shlomo Sela, Carlos Steel, C. Philipp E. Nothaft, David Juste \& Charles Burnett

There are no explicit references to Ibn Ezra as translator of these two texts but a scrutiny of the links between them and Ibn Ezra's work may be useful to furnish some clues. Let us begin with the first Kindian treatise in Part II. The closest one comes is in a list of countries and regions under the charge of a pair consisting of a planet and a zodiacal sign ascribed to Enoch. ${ }^{127}$ This list in Part II finds a counterpart in 'Olam I, although the list is ascribed in 'Olam I to Enoch, the Egyptian, various items do not appear in the same order as in Part II, and sometimes the details are not identical. ${ }^{128}$ There is also a close correspondence between Part II and 'Olam I regarding a list of planets and types of human beings under their charge. ${ }^{129}$ 'Olam I, though, ascribes this list to the ancient Enoch, and the order of presentation of the planets is different in these two sources.

Another interesting parallel is found in the last list of signs of cites of Part II. ${ }^{130}$ This list has its counterpart in 'Olam I, 'Olam II, Nativitates, Epitome, and Tractatus pluviarum. ${ }^{131}$ Remarkably, all these lists include references to the signs of Lucca and Pisa, two cities that correspond to what we know about Ibn Ezra's peregrinations in Italy. Olam II, Nativitates, Epitome, and Tractatus pluviarum, include also short notes implying that the author himself made observations to determine their signs, which allows us to surmise that Ibn Ezra also spent some time in Pisa. However, the list in Part II keeps silence regarding these observations, and includes only the degrees of the first two cities, whilst its items do not always correspond to the items in the parallel lists in Ibn Ezra's work.

Let us now turn to Part III. We have plenty of references in Ibn Ezra's oeuvre to al-Kindī, which include quotations or paraphrases from his books, but without specifying their titles or mentioning « al-Kindī in his book» or « in his books ». ${ }^{132}$ The only exception to this rule is a long quotation from al-Kindi's Book of the Revolution in 'Olam I. ${ }^{133}$ This title is similar to that assigned to the second Kindian

127 See Part II §4:1-7.

128 See 'Olam I, ed. Sela, \$37:1, p. 76-77.

129 See Part II §3:1; cf. 'Olam I, ed. SELA, §36:1, p. 76-77. There is also a similar list in Epitome, ed. JoACHIM HELLER (1548), I:5, sig. F3v.

130 See Part II §6:1-5.

131 'Olam I, ed. Sela, §38:1-24, p. 76-79; 'Olam II, ed. Sela, §15:1-25, p. 164-167; Nativitates, ed. Sela, I i 2:6-7, p. 82-83; Epitome, ed. JOACHIM Heller (1548), I:8, sig. G4r; Tractatus pluviarum, in CHARLES BuRNETT, «Weather Forecasting, Lunar Mansions and a Disputed Attribution: The Tractatus pluviarum et aeris mutationis and Epitome totius astrologiae of 'Iohannes Hispalensis' ", in ANNA AKasoy, Wim RaVen (eds.), Islamic Thought in the Middle Ages: Studies in Text, Transmission and Translation, in Honour of Hans Daiber, Brill, Leiden 2008 (Islamic Philosophy, Theology and Science: Texts and Studies, 75), p. 246.

132 See the lists of authorities mentioned in all the editions of Ibn Ezra's astrological writings.

133 'Olam I, ed. SELA, §44:1-6, 82-83: «Ya'qūb al-Kindī said in his Book of the Revolution: Observe the conjunction or opposition of the luminaries before the Sun enters Aries, whichever occurs last. If you find that the sign of the ascendant is a watery one, it indicates that there will be rain at this conjunction or opposition, particularly if the place of the conjunction or opposition is in one of 
treatise in the colophon of Part III: Book on the judgments of the revolutions of the world-years. ${ }^{134}$ Unfortunately, we find no verbatim match of this quotation in Part III although there is a passage ascribed to Kanakah, the Indian, that bears slight resemblances to the quotation from Al-Kindī's Book of the Revolution in 'Olam I. ${ }^{135}$

Al-Kindì's Book on the judgments of the revolutions of the world-years in Part III and Ibn Ezra in his whole astrological corpus address in similar terms a number of similar astrological doctrines. However, Ibn Ezra never acknowledges that he is following al-Kindī, as follows:

The dodecatemoria, a division of the signs into twelve parts; here 'Olam I also includes an example but ascribes the account to Dorotheus, the king. ${ }^{136}$

Finding which of two planets in conjunction is victorious or prevails over the other, ${ }^{137}$ here Ibn Ezra's ultimate source is Abū Ma'shar's Great Introduction. ${ }^{138}$

The 12 keys of the Moon, used for weather forecasting; here 'Olam I says that this doctrine has been verified by experience by the ancients and the moderns, and 'Olam II and the Epitome assign portions of power to the keys of the Moon, which Part III does not. ${ }^{139}$

The lunar mansions; while Part III names 6 lunar mansions signifying humidity, 'Olam I names 9, 'Olam II names 9 mansions of rain and three of moistness, and Epitome names 10 humid mansions; ${ }^{140}$ as for the position of the mansions, while

the cardines of the ascendant at this time, according to the latitude of the city for which you calculate the luminaries. But if the place of conjunction or opposition happens to be in one of the places falling <from the cardines>, judge that it will not rain during the entire month and the larger part of the year. If the sign of the ascendant is a watery one and the lord of the sign is in an aspect to it [the ascendant] as well, this is an absolute indication that rain will fall; if the lord of the ascendant is there, there will be even more <rain>. And if the lord <of the ascendant $>$ is with the luminaries, then rain will be extremely abundant. If you wish to know what day it will rain, find the day when the Moon reaches the degree of the ascendant - then it will rain ».

134 See colophon of Part III.

135 See Part III \$21:1-11.

136 See Part III §5:1-2; cf. 'Olam I, ed. SeLA, §32:1-8, p. 72-75; 'Olam II, ed. SeLA, §21:1-2, p. 170-171.

137 See Part III §6:1-4; cf. Țéamim I, ed. Sela, §7.1:4-10, p. 88-89; Téamim II, ed. Sela, §4.4:1-3, 210211; Moladot, ed. SELA, III, vii 4, 1-11, p. 160-163; 'Olam I, ed. Sela, \$21:1-4, 64-67; Me'orot, ed. SELA, §30:1-7, p. 474-475; She'elot I, ed. SELA, §7.3:10-19, p. 270-271; She'elot II, ed. SELA, §7.2:2, p. 370371; Mishpetei ha-mazzalot, ed. SELA, §33:1-7, §34:1-5, p. 516-519. Electiones, MS Erfurt, UFB, Amplon. 0.89, fol. 45r; Epitome, ed. JOACHIM HeLleR (1548), XXIII, sig. D3v.

138 Great Introduction, ed. BURNETT, YAMAMOTO, VII:4, [8] p. 746-747.

139 See Part III §12:1-2; cf. 'Olam I, ed. SelA, §47:4, §48:1-14, p. 84-85; 'Olam II, ed. Sela, §18:1-13, §19:110, p. 168-169; Epitome, ed. JOACHIM Heller (1548), I:3, sig. F2v-F3r.

140 See Part III §10:2; §13:1-4; §15:1; §16:1; §22:2,4; cf. 'Olam I, ed. SeLA, §62:1-5, p. 92-93; §63:1-11, p. 92-95; 'Olam II, ed. SELA, §37:4, p. 180-181; §43:1-4, p. 184-185; §44:1-3, p. 184-185; §45:1-4, p. 184-185; §49:6, p. 188-189. Ibn Ezra devoted complete chapters to the 28 lunar mansions in Nehoshet I, MS heb. Paris 1061, fols. 156v-157r and Nehoshet II, MS heb. Paris 1061, fols. 193r-194r. See also Epitome, ed. JoACHim HeLler (1548), I:11, sig. H1v-H2v. 
Shlomo Sela, Carlos Steel, C. Philipp E. Nothaft, David Juste \& Charles Burnett

Part III says that there is need to subtract 9 equal degrees from the position of the Sun and the Moon and from the position of the other planets, 'Olam I speaks of $8^{\circ}$.

The calculation of the lot of rain; while Part III assigns this lot to Sahl, the Jew, Reshit Hokhmah ascribes the same lot to Enoch and its ultimate source is Abū Ma'shar's Kitāb al-sirr. ${ }^{141}$

From this survey of links between Part II and Part III, on the one hand, and Ibn Ezra's astrological corpus, on the other, it emerges that at the present stage we do not have solid evidence indicating that Ibn Ezra was the translator of the two treatises ascribed to al-Kindi in part II and Part III. In addition, the Latin translations in Part II and Part III do not reveal any trace of Ibn Ezra's peculiar terminology, in contrast with that of Part I. We may surmise, then, that the two Kindian treatises in Part II and Part III were translated from Arabic into Hebrew after Ibn Ezra's death, as in the case of al-Kindì's Letter on moistures and rain and On the causes $<$ of the forces $>$ attributed to the higher bodies, which indicate the origin of rains, translated from Arabic into Hebrew by Kalonymus ben Kalonymus ben Me ir between 1307 and 1317. ${ }^{142}$

\section{I.6. The al-Kindī Connection (Charles Burnett)}

The question is whether the two treatises attributed to al-Kindī (Part II and Part III) are genuinely by al-Kindī, and if so whether an original text can be identified or, failing that, whether sufficient parallels in other works of al-Kindī can be found. The first problem is that the Latin text states that the work was 'compiled' ('collegit/compilavit') by al-Kindī rather than 'composed', and both treatises do, in fact, consist largely of quotations - Enoch (Hermes), the scholars of Babylon, Māshāallāh, Kanakah, the scholars of Persia, and Sahl (Ibn Bishr). Compilation is not a style recognizable in the extant works of al-Kindi, which develop arguments of the author's own or present doctrine without indicating its origin (e.g., in alKindī's work on astrological judgements, The Forty Chapters). It may be more profitable to search for the texts that have been compiled. The second problem is that al-Kindî's doctrine on general or mundane astrology (which includes weather forecasting and the lunar mansions), appears in several texts or excerpts, under different titles, and in different languages: Fi tahwill al-sina ('On the Revolution of the Year'), Sefer he-Tekufah (Liber revolutionum), chapters from Al-arba'üna bāban ('The Forty Chapters'; Iudicia astrorum), Risāla fì ahdāth al-jaww ('Letter on the Phenomena of the Atmosphere'), Saturnus in Ariete ('Saturn in Aries'), and two

141 See Part III §22:1-7; cf. Reshit Hokhmah, ed. Sela, §9.19:3-4, p. 260-261; 'Olam II, ed. SelA, §40:1-4, 182-183; BURNETT, « Weather Forecasting », p. 234.

142 See GerRit Bos, CHARles BuRnetT, Scientific Weather Forecasting in the Middle Ages: The Writings of alKindī, Kegan Paul International, London and New York 2000, p. 52-53. 
letters fully extant only in Hebrew translations: Iggeret ba-Lahuyyot u-va-Matar ('Letter I, On Moistures and Rain') and Iggeret ba-'Illot ha-Meyuhasot el ha-Isshim ha'Elyonim ha-Morot 'al-Hawayat ha-Geshamim ('Letter II, On the Causes of the Forces Attributed to the Higher Bodies, which Indicate the Origin of Rains') - the letters were combined (probably already in Arabic) in a treatise extant only in Latin under the title De mutatione temporum ('On the Changes of the Weather'). ${ }^{143}$ In addition, there is a Maqāla Tahāwizl al-Sinin ('Discourse on the Revolutions of the Years'), extant in MS Escorial, Real Biblioteca del Monastario de San Lorenzo, 918/2, fols. $10-11 .^{144}$ It is unclear how many texts are involved, and how much overlap there is between the content of these texts. It is quite plausible, that another Arabic text (or texts) lies behind the two treatises of al-Kindi edited here (Parts II and III), even though al-Kindī is not otherwise known for writing compilations. Comparisons yield the following information:

In spite of the similarity of the title, Part II ('On the Judgements of the World Years') does not include any passage corresponding to the quotation from the 'Book of the Revolutions (of the years)' by al-Kindī cited by Ibn Ezra in his Sefer haOlam I and as 'The Book of the Revolution of the year' in MS Tehran, Majlis-i ShūrāMilli 6452 (both edited in Bos and Burnett, p. 421-433).

Part III, on the prediction of weather and the lunar mansions, does not correspond in a sustained way to any section of al-Kindī's Letter II, largely because, for al-Kindī in the Letter, following the Indians, the lunar mansions are 27 in number, rather than 28 . Hence the differences between the following passages: ${ }^{145}$

\begin{tabular}{|c|c|}
\hline Part III & Letter II (Bos and Burnett, p. 254) \\
\hline \$13 (1) There are six lunar mansions & 90 When the Moon dwells in six of these \\
signifying humidity, as follows: ${ }^{146} 4,12,16$, & $<$ mansions>, namely 4, 7, 12, 16, 21, 26, \\
17, 22, 27. (2) There are six dry mansions: & rain, water and humidity are increased. \\
$2,6,9,18,25,26 .(3)$ The other mansions & 91 Six mansions, namely 2, 5, 9, 17, 24, 25, \\
$\begin{array}{l}\text { are temperate or moderate. (4) You will be } \\
\text { able to know the mansions in this manner: }\end{array}$ & are dry and do not indicate rain. 92 Eleven \\
\hline
\end{tabular}

143 All the extant texts and excerpts attributed to al-Kindi and mentioned up to this point, have been edited and translated in BOS, BURNETT, Scientific Weather Forecasting. A paragraph of the Arabic text of Letter II, 144-147 (ed. Bos, BuRNETT, p. 241 and 260) is quoted in Abū 'Abd Allāh al-Baqqār, Kitāb al-amtāar wa-l-as'ār ('Book of Rains and Prices'), 131: see CHEDLI GuESMI, Julio SAMsó, Astrometeorología en al-Andalus y el Magrib entre los siglos VIII y XV, Brepols, Turnhout 2008.

144 For a translation into Spanish, see RAFAEL MUÑOZ JIMÉNEZ, « Una maqāla astrológica de al-Kindī », Boletín de la Asociacion Española de Orientalistas, 15 (1979), p. 127-139.

145 The other differences are that al-Kindī, Letter II, makes mansion 7 humid, whereas Part III makes mansion 17 (the 'extra' mansion) humid; and al-Kindī, Letter II makes mansion 5 dry, whereas Part III makes mansion 6 dry. Both 7 and 17 are humid, but 6 is moderate; Part III may have made a mistake.

146 Part III gives numbers and names; I have omitted the names here; Letter II gives only the numbers. 
Shlomo Sela, Carlos Steel, C. Philipp E. Nothaft, David Juste \& Charles Burnett

take into consideration in which mansion mansions are moderate, neither moist

the Moon is seen... nor dry.

There is, however, a close and sustained correspondence between Part III §18-20, and the text called Risāla fi ahdāth al-jaww ('Letter on the Phenomena of the Atmosphere'; Bos and Burnett, p. 409-419), as follows: ${ }^{147}$

\begin{tabular}{|c|c|}
\hline Part III & \\
\hline $\begin{array}{l}\text { \$18 (1) I will now give you a common and } \\
\text { general rule to know the essence of cold, } \\
\text { heat, humidity and dryness. (2) Take } \\
\text { always into consideration whether Saturn } \\
\text { and Jupiter are in the figures of the } \\
\text { uppermost circle, for Saturn signifies time } \\
\text { in its entirety and Jupiter the year. }\end{array}$ & $\begin{array}{l}1 \text { The first indication for heat and cold and } \\
\text { the other <qualities> occurring in the } \\
\text { atmosphere is from Saturn and Jupiter, for } \\
\text { Saturn is the indicator of the quarter, and } \\
\text { Jupiter the indicator of the year. }\end{array}$ \\
\hline $\begin{array}{l}\text { \$18 (3) Examine the moment of the entrar } \\
\text { of the Sun into the head of the mobile signs a } \\
\text { observe whether the two upper <planets }>\text { c } \\
\text { in hot signs, because then this quarter of t } \\
\text { year will be hot; and if in cold, it will be co } \\
\text { and if in humid, it will be humid. If they are } \\
\text { different places, as when one is in a hot si } \\
\text { and the other in a cold, this quarter will } \\
\text { temperate, and the same applies to humid } \\
\text { and dryness. }\end{array}$ & $\begin{array}{l}2 \text { When the Sun enters the first minute of every } \\
\text { mobile sign, look at the place of Saturn and } \\
\text { Jupiter; when they are both in hot signs, that } \\
\text { quarter is hot, and when they are in cold signs, } \\
\text { it is cold, and the same in humidity and } \\
\text { dryness. } 3 \text { If they are different and one of } \\
\text { them is in a hot sign and the other in a cold } \\
\text { sign, the quarter is moderate between heat } \\
\text { and cold, and likewise in humidity and } \\
\text { dryness. }\end{array}$ \\
\hline $\begin{array}{l}\$ 20 \text { (1) Moreover, Abū Ma shar said: The } \\
\text { great key of rain is when Saturn conjoins the } \\
\text { Sun at the moment of the conjunction or } \\
\text { opposition <of the luminaries>, or when it is } \\
\text { in any aspect to it, at the moment of the } \\
\text { keys of the Moon, because then it signifies } \\
\text { heavy rain for many days. }\end{array}$ & $\begin{array}{l}9 \text { The greater opening is the application of the } \\
\text { Sun to Saturn. Saturn is like the male } \\
\text { principle, the Sun like the female } \\
\text { principle. There is no generation of times } \\
\text { without both of these. } 10 \text { And when it } \\
\text { applies to Saturn in the conjunction or } \\
\text { opposition or quartile or one of the } \\
\text { numbered mansions of the Moon, the air } \\
\text { becomes humid. }\end{array}$ \\
\hline $\begin{array}{l}\text { \$20 (2) The sma } \\
\text { one planet, in it } \\
\text { planet that is } t \\
\text { detriment or de } \\
\text { conjoins Jupiter, } \\
\text { with a strong } \\
\text { Mars <signifies> } \\
\text { thunder; the Mc } \\
\text { strong frost anc }\end{array}$ & $\begin{array}{l}\text { ler opening is the application of } \\
\text { the lower planets with the Lord } \\
\text { opposite to its house. } 12 \text { When } \\
\text { olies to Jupiter, humidity occurs } \\
\text { hwinds, and when Venus applies } \\
\text { umidity occurs together with } \\
\text { ununder and thunderbolts, and } \\
\text { Ioon applies to Saturn, humidity }\end{array}$ \\
\hline
\end{tabular}

147 Correspondence is indicated by italics. 


\begin{tabular}{|l|l|}
\hline & $\begin{array}{l}\text { occurs together with tranquillity, } \\
\text { coldness, snow, hail, ice, and destructive } \\
\text { rain. }\end{array}$ \\
\hline
\end{tabular}

In Part III $\$ 20$ is attributed to Abū Ma'shar whereas there are no citations of authorities in the Risāla fĩ ahdāth al-jaww (which is typical of the genuine al-Kindī). This correspondence is not sufficiently close for the Risāla fi ahdāth al-jaww to be regarded as a direct source for Part III, but the fact that the order of the material is the same in both texts strongly suggests a common transmission of doctrine.

The lot of weather in Part III $\$ 22$ corresponds to a Latin addition to the al-Kindi Letters (i.e. in the joint letter De mutatione temporum, 7.L6-7; ed. Bos and Burnett, p. 299), which in turn corresponds to a passage in 'Umar ibn al-Farrukhān's Kitāb mukhtașar al-masā'il ('The Abbreviated Book of Interrogations'), ch. 81 (Bos and Burnett, p. 444) and the Tractatus Pluviarum et aeris mutationis secundum magistrum Iohannem Yspalensem. ${ }^{148}$ In Part III the description of this lot is attributed to Sahl the Jew (= Sahl ibn Bishr); in 'Umar it is attributed to Abū Ma'shar. The correspondence is as follows:

\begin{tabular}{|c|c|c|c|}
\hline Part III & $\begin{array}{l}\text { De mutatione } \\
\text { temporum }\end{array}$ & $\begin{array}{l}\text { 'Umar ibn al- } \\
\text { Farrukhān }\end{array}$ & $\begin{array}{l}\text { Iohannes } \\
\text { Yspalensis }\end{array}$ \\
\hline $\begin{array}{l}\text { \$22 (1) Sahl the Jew } \\
\text { also said: you must } \\
\text { take account, for the } \\
\text { day under } \\
\text { consideration, of the } \\
\text { lot of weather, which } \\
\text { will know in this } \\
\text { way: (2) You need to } \\
\text { measure, for the day } \\
\text { under consideration, } \\
\text { the longitude between } \\
\text { the place of the Sun and } \\
\text { that of Saturn, and cast } \\
\text { this number from the } \\
\text { place of the Moon in the } \\
\text { morning, at sunrise, } \\
\text { and look whether } \\
\text { this lot falls in one of } \\
\text { Saturn's houses, }\end{array}$ & $\begin{array}{l}\text { Chapter 7, L6 } \\
\text { Inspect also the lot } \\
\text { of the days, i.e. } \\
\text { measure <the } \\
\text { degrees> from the } \\
\text { degree of the Sun to } \\
\text { the degree of Saturn } \\
\text { and cast <this } \\
\text { number> from the } \\
\text { degree of the Moon } \\
\text { towards the rising } \\
\text { of the Sun }{ }^{149} \text { for the } \\
\text { whole day. }\end{array}$ & $\begin{array}{l}\text { Chapter 81: Another } \\
\text { lot which was } \\
\text { mentioned by Abū } \\
\text { Ma'shar ... and is } \\
\text { called the lot of the } \\
\text { days is: measure <the } \\
\text { degrees> from the } \\
\text { degree of the Sun to } \\
\text { the degree of Saturn } \\
\text { and cast <this } \\
\text { number> from the } \\
\text { degree of the Moon at } \\
\text { the moment of the } \\
\text { rising of the Sun } \\
\text { every day. }\end{array}$ & $\begin{array}{l}25 \text { Et quot sint } \\
\text { gradus equales } \\
\text { inter Solem et } \\
\text { Saturnum } \\
\text { quoque mane } \\
\text { considera et } \\
\text { totidem gradus } \\
\text { computa a loco } \\
\text { Lune: quo } \\
\text { pertingunt, ibi } \\
\text { pars pluvie erit. }\end{array}$ \\
\hline
\end{tabular}

148 Edited in BURNETT. « Weather Forecasting », p. 257. Note that the interpretation of the 20th lunar mansion as being « secundum Hispalensem » (Part I, 3:1) is different from the interpretation in this work.

149 This probably means « in an easterly direction », which could be the meaning in Part III also. 
Shlomo Sela, Carlos Steel, C. Philipp E. Nothaft, David Juste \& Charles Burnett

\begin{tabular}{|l|l|l|l|}
\hline $\begin{array}{l}\text { because this signifies } \\
\text { obscurity of the sky, } \\
\text { if Saturn aspects it } \\
\text { and if it is in any of } \\
\text { the lunar mansions } \\
\text { signifying rain. }\end{array}$ & & & \\
\hline $\begin{array}{l}\text { \$22 (3) If the Moon } \\
\text { falls in one of the } \\
\text { houses of Jupiter or } \\
\begin{array}{l}\text { Mercury, this signifies } \\
\text { winds. }\end{array}\end{array}$ & $\begin{array}{l}\text { L7 If Mercury } \\
\text { aspects this lot or } \\
\text { it coincides with } \\
\text { Mercury, there will } \\
\text { be wind on that } \\
\text { day. }\end{array}$ & $\begin{array}{l}\text { If Mercury aspects } \\
\text { this lot or it } \\
\text { coincides with } \\
\text { Mercury, there will } \\
\text { be strong winds on } \\
\text { that day. And they } \\
\text { will be even } \\
\text { stronger when the } \\
\text { Moon is in it. }\end{array}$ & $\begin{array}{l}\text { 26 Que } \\
\text { computatio si } \\
\text { erit in domo } \\
\text { Lune vel } \\
\text { Veneris, } \\
\text { significat } \\
\text { pluviam, si in } \\
\text { domo Mercurii } \\
\text { vel Iovis, } \\
\text { significat } \\
\text { ventos, si } \\
\text { Martis vel Solis, } \\
\text { serenitatem, si } \\
\text { Saturni, } \\
\text { significat nubila }\end{array}$ \\
\hline
\end{tabular}

A consultation of Abū Ma'shar's Kitāb al-Sirr (see Bos and Burnett, p. 382) and Sahl ibn Bishr's Kitāb tahāāil al-sinin wa-mā yahdathu fí al-'ālam ('Book of the Revolutions of the Years and that which Occurs in the World' or Fatidica) might reveal the original passages which lie behind these quotations.

The enumeration of the 'keys' of the Moon (i.e. significant phases) in Part III \$13, has a parallel in al-Kindī, Iudicia, chapter 5, 675 (ed. Bos and Burnett, p. 398, 401, 404, 406; only in Robert of Ketton's translation, ibid, p. 404, is the full list given). But a closer source would be Ibn Ezra, Sefer Ha-Olam (I), quoting «Abū Shāriq » (Bos and Burnett, p. 49). The value of the 'body' of each planet in Part III $\$ 14$ (4) is found widely - e.g. in Abū Ma'shar, Great Introduction, VII, chapter 3 (ed. Yamamoto and Burnett, p. 739), but not (as far as I know) in other works of alKindī.

Thus there is no independent proof that Parts II and III are taken from genuine works (or from one work) of al-Kindī, though this attribution remains plausible. 


\section{I.7. Description of the Manuscripts \\ (David Juste)}

\section{Vatican, Biblioteca Apostolica Vaticana, Pal. lat. 1407}

s. XIV ${ }^{\text {ex }}-X^{\text {in }}$ (Schuba). ORIGIN: Germany (Schuba), perhaps Liège. The opening text (fols. 1r-1v), addressed to an unnamed master in Liège shortly before 10 July 1387, is perhaps by Eustachius de Eldris, who is otherwise known as the author of an astrological work, De directionibus, written in Liège in 1390. One of the two extant MSS of De directionibus also preserves Henry Bate of Mechelen's Nativitas (MS Segovia, Archivo y Biblioteca de la Catedral, B 349), while the present manuscript contains works translated or authored by Bate (fols. 55r-71v). This suggests that the present manuscript (at least fols. 9-71, all in one hand) derives from a manuscript owned by Bate himself, which he would have left in Liège. PROvENANCE: Elector Palatine Ottheinrich (1502-1559); Heidelberg, Bibliotheca Palatina, by 1556; Vatican library in 1623.

Paper, 154 fols., three main hands (fols. 1, 9-71 and 75-152).

Astrology: Eustachius de Eldris (?), judgement on the conjunction Saturn-Mars of 10 July 1387 « Reverendissimo in Christo patri ac domino domino meo Leodien<si> licet indignus as nullius inter astrorum sapientes sufficientie sum reputandus solacii tamen causa cum magna diligentia... » (1r-1v); astronomical diagram: motion of Mercury (2r); $16^{\text {th }}$-c. table of contents (covering fols. 9-152) by a librarian of the Bibliotheca Palatina (8v); Albumasar, Flores (9r-18r); Zael, Fatidica (18r-38r); Albumasar, De revolutionibus annorum mundi (38r-55r); Abraham Avenezre, De revolutionibus annorum mundi (55r-58r); Alkindi (?), Liber de iudiciis revolutionum annorum mundi (58r-62r); Henry Bate of Mechelen, De diebus creticis periodorumque causis (63r-71v); Guido Bonatti, Liber introductorius ad iudicia stellarum, Book IX on nativities (75ra-152ra), preceded by a chapter index added by a later hand (73r74v). Blank: fols. 2v-8r (except short note fol. 2v), 62v, 72, 152v-154.

LIT.: Ludwig Schuba, Die Quadriviums-Handschriften der Codices Palatini Latini in der Vatikanischen Bibliothek, Reichert, Wiesbaden 1992 (Kataloge der Universitätsbibliothek Heidelberg, 2), p. 183-184.

\section{London, Royal College of Physicians, 384}

s. XV ${ }^{\text {ex }}-X I^{\text {in }}$ (after 1481, date of the printed edition of Bartholomaeus de Paczków's Commentum in Ephemeridem Regiomontani fols. 87r-93r; the year 1470 is mentioned fol. $98 \mathrm{r}$; the date 1405 , given in a colophon on fol. $9 \mathrm{v}$, is either a mistake or the date of the exemplar). ORIGIN: England.

Paper, 112 fols. (foliated 1-86 and 1-26), a single hand. 
Shlomo Sela, Carlos Steel, C. Philipp E. Nothaft, David Juste \& Charles Burnett

Astrology and astronomy in English (fols. 1r-98v and 101r-101v) and in Latin (fols. 99r-100r and 102r-112v): 16 questions on thunder, lightning and related phenomena "The phylosofyr saith in a boke $p^{t}$ he makith...» (1r-3r); Iudicia Herfordensis multum bona et utilia, English (4r-6r); Messahallah, Liber de intentionibus secretorum astronomie, English ( $6 \mathrm{r}-9 \mathrm{v})$; " Of these thingis forsoth $\mathrm{p}^{\mathrm{t}}$ belongen to iudicials of sterris for to be had in mynde these 6 arne... » $(9 \mathrm{v}-13 \mathrm{r})$; tables: meteorological prognostics from the association of pairs of planets in each of the 12 signs $(13 \mathrm{v}-25 \mathrm{v})$; note « In knowyng of the partyes of the yere if thingis... » (25v); « Off the parte of water in many thingis... » (25v-26r); Alkindi (?), Saturnus in Ariete sub radiis... attr. Haly, English (26r-26v and 27v-28r); short text on the unseen urine "A tracte to discerne uryne what it is not seen... » (27r); Messahallah, Epistola de rebus eclipsium, English (28r-30r); elections and various astrological considerations « For Iorneys. Thys chapter is of eleccions of tyme... » (30v-33r); Albumasar, De revolutionibus annorum mundi, English (37r-48r); Sacrobosco, De sphera, English (48r-54r); « Here mayst $p^{u}$ know in how many maner an astronomyer may arre in 4 maner thingis... » (54r-56v); sign-book « Aryes is pe fyrst syngne of pe zodiake... » (57r-59v); Hermes/Enoch, Liber imaginum signorum, English (60r-61r); "Of nativites. Profithith hym not after $\mathrm{p}^{\mathrm{t}}$ dresse... » (61v-70r); " Haly Abenragell of nat<ivites>. This chapter if of nativites of childer taken out Haly Abenragell... » (70r-72r); canons of astronomical tables « Canon de Sole. To know and finde the mene mote... » (72r-74v); « For to knowe pe state of a seke man. This chapter is of knowinge of pe state of a seke man... » (75r-78r); « As I had loked and weyn of ... [blank] of planetis I fonde Mercuri...» (78r-83v); Abraham Avenezre, De revolutionibus annorum mundi and Alkindi (?), Liber de iudiciis revolutionum annorum mundi, abridged version (83v-85r); Astronomia Ypocratis, English (85r-86r); « For to fynde the VII planetis... » (86r); table: elections from the aspects of the Moon with the other planets (86v); Bartholomaeus de Paczków, Commentum in Ephemeridem Regiomontani, English (87r-93r); astrological chapters « This forsaid tabi lis callid tabula Lune... » (93r-98v and 101r-101v); Guillelmus Anglicus, De urina non visa (99r-100r); Gergis, De significatione septem planetarum in domibus attr. Ptolemy (102r103v); "Incipit liber Zael. Incipiunt significationes planetarum per signa secundum Zael philosophum. Saturnus cum fuerit in signis hominum... » (103v); «Liber Zael de coniunccionibus. Coniunccio est quando due planete merguntur in eodem signo... » (103v-104r); Michael Scot, De noticia ordinum stellarum fixarum celi seu ymaginum 48, incomplete (104r-107v); Albumasar (?), Liber similitudinum attr. Ptolemy (108r-110v); " Forma de nova intrumentur (!) navicula dicto pro horis equalibus ubicunque in tota terra inveniendis. In hoc intrumento due figure zodiaci... » (111r); Messahallah, Epistola de rebus eclipsium, beginning only (111v), followed without a break by «Item Aristoteles: Notandum est quod principatus planetarum in conceptione humana...» $(111 \mathrm{v}-112 \mathrm{r})$; "Tabulatus 12 signorum. Aries calidus et siccus, masculum, diurnum... » (112r-112v); note « De dominatore 
rei s... (?). Cum scire volueris dominatorem rei... ( (112v); Bethen, Centiloquium c. 232 (112v). Blank: fols. 3v, 100v.

LiT.: Neil R. Ker, Medieval Manuscripts in British Libraries, vol. I: London, Clarendon Press, Oxford 1969, p. 212-215; John D. North, "The Longitudes of Winchester ", Cahiers de l'Institut du Moyen-âge Grec et Latin, 73 (2002), p. 13-20 (13-14); John D. North, « Winchester 1067 », Centaurus, 45 (2003), p. 130-141; Catherine Eagleton, Monks, Manuscripts and Sundials. The Navicula in Medieval England, Brill, Leiden 2010 (History of Science and Medicine Library, 13; Medieval and Early Modern Science, 11), p. 171-172. 
Shlomo Sela, Carlos Steel, C. Philipp E. Nothaft, David Juste \& Charles Burnett

\section{EDITION AND TRANSLATION OF THE LATIN TEXT}

\section{II.1. Introduction \\ (Carlos Steel)}

MS Vatican, BAV, Pal. lat. $1407(\mathrm{~V})$ is the only manuscript that has preserved Bate's translation of the treatises of Ibn Ezra and 'Alkindi' on the revolutions of the year. ${ }^{150}$ One finds the translation in the oldest part of the MS (fols. 9r-71v), which was copied in the late fourteenth century. The translation comes after Albumasar, Flores (9r-18r); Zael, Fatidica (18r-38r); Albumasar, De revolutionibus annorum mundi $(38 \mathrm{r}-55 \mathrm{r})$ and is followed by Henry Bate's own De diebus creticis (63r-71v). There is no title, and the scribe was uncertain what to make of the series of texts he found in his model after Albumasar's treatise. Instead of a title he simply wrote: "Sequitur capitulum uel sequuntur capitula, sed non inueni plus ». A later scholar, who also annotated the text $\left(\mathrm{V}^{2}\right)$, having noticed the colophon at the end, wrote in the margin "liber Jacob Alkindi de reuolutionibus annorum mundi ", and in the margin of the first 'Alkindi' text "Alius tractatus Alkindi». The colophon unambiguously attributes the translation of the 'Alkindi' texts to Henricus Bate:

Explicit liber de iudiciis reuolutionum annorum mundi quem compilauit Iacob filius Ysaac Alkindi. Expletus est libellus iste ascendente Cancro, in quo Luna coniuncta Ioui, die tertia Septembris anno domini $1278^{\circ}$ in Mechlinia, translatus ex Hebrayco in Latinum per Henricum Bate ad preces Iohannis de Milana.

The use of astrological references to date a translation is characteristic of the colophons of Bate's translations. ${ }^{151}$ The translation was made « at the request of Johannes van Milanen ». We know that Johannes was for many years alderman (scabina) of the city of Mechelen and that he was related to Henricus. He probably was his uncle on his mother's side. ${ }^{152}$ The colophon surprisingly only indicates that Bate translated the 'Alkindi' texts from Hebrew into Latin. Yet, there is no doubt that Bate also translated the first text by Ibn Ezra, as it shows the same translation method as the 'Alkindi' treatises. Thus, one finds double translations of a same Hebrew term, which is characteristic of all Bate's translations. ${ }^{153}$ Moreover, there are in this first text similarities with terms and phrases used by Bate in his other

150 For a description of this MS see the contribution of David Juste, who first noticed this so far unknown translation of Bate.

151 See for a survey of the colophons, see David Juste in StEeL et al. (eds.) The Astrological Autobiography, p. 49-54.

152 See Ibid., p. 35 , n. 38 and p. 39 n. 69.

153 See Ibid., p. 37. For more arguments to attribute the first part of the translation to Bate, see Sela's introduction, p. 38-39 
works. Thus, $\$ 6.1: 6$ « et re uera mirabile est »: cf. Nativitas 1266 « et re uera mirabile est », or « uniuersaliter» (\$1.1:1), « experior » (\$2.2:2) with a direct object or «sustentari super» (\$3.3:2 and §4.1:1) are frequently used by Bate in other translations. Noticeable is also the translation of the equator as « linea equalis sive medium mundi » (\$3.3:3), cf. De rationibus, MS Leipzig, UB 1466, where equator is translated as « equalis linee siue equinoctialis » $(62 \mathrm{v})$ « linea equalis » $(62 \mathrm{v})$, « in medio celi » (63r). One can also notice similarities in Bate's translation of Téamim I, §1.5:12-14 (Leipzig 1466, f. 62ra) and our text §2.5:8-9:

Saturnus uero quia remotus a terra, propter hoc lumen eius non est generatiuum caloris secundum proportionem temperamenti conuenientis homini, quamquam lumen per se generatiuum sit caloris. Cuius exemplum est hoc quod dicunt sapientes medicine quod caro bouina frigida est; et uerum dicunt secundum quod comparatur ad corpus humanum. Est tamen calida secundum quod est caro.

(\$2.5:8-9) Non dixerunt autem de Luna quod sit frigida nisi quia caliditatem non generat humane complexionis temperamento similem seu conuenientem. Secundum quod dixerunt medici carnes bouinas frigidas esse et scitum est quod omnis caro calida est nisi quod respectu temperamenti complexionis humane ipsa frigida est et ei nociua. Consimiliter ergo et Saturnus quia ualde remotus est a terra et corpus eius ita grande non est ut corpus Iouis, idcirco dixerunt et ipsum esse frigidum. (MS Leipzig, fol. 62ra)

One finds even a 'signature' of Bate himself in this first part, in a note added after the tables on the " mansiones lune ». In the second table Ibn Ezra gives a list of the 28 mansions with their zodiacal names and the degrees, minutes and seconds that each contains. On the right side of the table it is indicated whether the mansions are temperate, dry or humid. This table ends with the following note: « Note that there are six mansions that are principally humid, according to the evidence provided by Al-Kindī, and that Ibn Ezra enumerates only those as humid, although other mansions are moderately humid, and they have been indicated here ». The scholar who made this note can obviously not be Ibn Ezra himself, as he refers to him. It is most probably the translator Henricus Bate who added it. He noticed that, in this table, Ibn Ezra only marked six mansions as humid and that he thus followed the view of 'Alkindi' in the second treatise (III, § 13). However, one may also characterise five other mansions as 'humid' though they are only moderately humid. As the note says, these supplementary humid mansions have been " indicated here » (" et sunt ille que hic sunt significate »): hic, that is, in this tabula. And indeed, for the mansions 7, 10,15, 19 and 20, which are "temperate », one finds in the margin, for each case, added «+ humida » with, in the fifth case, also added "secundum Hispalensem et Indorum tempora ». As those additions are in the same hand as the main text, the scribe of $V$ must have found them in the margin of the exemplar he used, which is probably Bate's own MS. The scholar 
Shlomo Sela, Carlos Steel, C. Philipp E. Nothaft, David Juste \& Charles Burnett

[Bate] who added these supplementary humidas did so because he had compared Ibn Ezra's list with what he found in the Epitome of (pseudo-)John of Seville. In fact, the author of the Epitome characterizes also mansions 7, 10, 15, 19 and 20 as humida. ${ }^{154}$ Moreover, the author also refers to the 'Indians' for this view: «Indi dicunt quod mansiones que pluviam significant sunt $11 »(6+5$ additional). There is no doubt that Bate compared the list of the mansions with the Epitome of the Hispalensis, as he himself says in the note. Moreover, the second list has a title " Tabula mansionum Lune correcta iuxta concordantiam philosophorum ». Again, it seems to have been the translator, not Ibn Ezra, who added this title, or at least its last part "iuxta concordantiam philosophorum ». In fact, it is only with the additional references to Hispalensis that this table has become a 'concordance'. Moreover, the use of the term 'philosophi' for astrologers definitely points to Bate and not to Ibn Ezra. As one can notice in his Nativitas, Bate constantly refers to the astrologers as philosophers. ${ }^{155}$ That Bate had a particular interest in the mansiones lunae is also clear from an annotation in his translation of Ibn Ezra's 'Olam I (De mundo). At $\S 62$ («Sapientes Indorum »), which one finds in MS Leipzig, UB 1466, most probably a copy of an exemplar that belonged to Bate: « illud capitulum est de m(ansionibus) supra (quas) Iacob Alkindi in libro reuolutionum $»{ }^{156}$ This note, which Bate may have added to his own copy, undoubtedly refers to the second 'Alkindi' text in this edition. ${ }^{157}$

If Bate is the translator of the first text and even shows that he knows that it comes from Ibn Ezra, it remains puzzling that he does not mention Ibn Ezra in the colophon. Did he consider the first text as an introduction to the 'Alkindi' texts? After all, when Bate started translating, al-Kindī was better known among Latin scholars than Ibn Ezra. Yet, his translation project in Mechelen, which started in 1273, when Bate had obtained his first ecclesiastical prebend, is almost entirely devoted to the work of Ibn Ezra. It included, however, also a translation from the Hebrew of Albumasar's De revolutionibus annorum for 'Le livre Even-Massar des revolucions du siecle' is found among Hagins' translations of Ibn Ezra in MS Paris,

154 See BURNETT, « Weather forecasting », p. 249-253.

155 In the preface Bate declares that he will follow the « judgments of the philosophers » (Nat. 19-21: " inducam ad meipsum alios iudices, puta philosophos ueritatis amatores cum sententiis suis et iudiciis ». That these philosophers are in fact astrologers is clear from what follows. See Nat. 9697: « Nam, ut testantur philosophi supra nominati cum aliis non nominatis hic » (i.e. Albumasar, Ptolemy, Hermes, Ibn Ezra) or Nat. 283-285 « Signa autem dominorum suorum significationes gerunt, ut uolunt philosophi »).

156 See on these notes in the Leipzig MS my forthcoming edition «Henry Bate's Translation of Ibn Ezra's treatise The Book of the World. A Critical Edition», in MARIENZA BENEDETTO (ed.), Le stelle, i regni, le credenze e le masse. L'astrologia politica nel Mediterraneo fra Medioevo e Rinascimento, Pagina - Brepols, Bari - Turnhout (forthcoming).

157 One may notice also the presence of two treatises on rain and weather forecasting (by Japhar and by Zael) in MS Paris BNF, n.a.l. 3091, a manuscript that probably was Bate's own personal copy. 
BNF fr. 24276. Bate must have discovered a precious collection of Hebrew manuscripts that originated from Ibn Ezra, which may even have included some early Latin translations. Yet, it remains puzzling why Bate started translating this tripartite collection and why he did not refer to Ibn Ezra in his colophon.

\section{II.1.1. The Transmission of the Text}

The Vaticanus MS is the only witness of the Latin text. There is, however, an English translation of an abridged compilation of the text made by an English scholar in the late fifteenth century (London, Royal College of Physicians, 384): see the edition by Philipp Nothaft in this study. I compared for my edition the Latin with the English version when available and noticed only a few variant readings: see $n$. 41 numerum] month (mensem ?), 63 radium] degrees (gradum?), 52 dispositionem] " of the Mone » added, 58 and 59 transposition of terms. These variants do not as such exclude that the English scholar used the Vaticanus version for his translation, for they could have been errors, additions, or interpretations of this scholar. More important are several numerical variants in the calculation, which are discussed by Nothaft and Juste, in particular in \$7.1:22, where the Latin reads $6^{\circ} 05^{\prime}$ Capricorn, but the English version has $10^{\circ} 05^{\prime}$. They seem to exclude that the English version is based upon V. Moreover, it is implausible that this scholar ever had access to the Vaticanus manuscript, which originated in Germany and never left Germany. Moreover, the content of the London MS is entirely different from that of $V$.

The scribe of $V$ refers in three instances to a variant reading. See n. 29:34.24] in aliis $48.13 \mathrm{mg}$. $V, 55$ radio] in al' aspectu $\mathrm{mg} . V, 60$ aquatico] in alio Aquarii $\mathrm{mg}$. $V$. One should not conclude from these few instances that the scribe had access to another copy of the text. Most probably he found the variant readings in his model, which may have been Bate's own copy. A later scholar $\left(V^{2}\right)$, who added the titles with reference to al-Kindī, also made some corrections in the text: they are almost always Verschlimmbesserungen except the conjectural addition of 'et Saturni', which is confirmed by the English version (see n. 64).

An important indirect witness of the text is Pierre d'Ailly. In his De concordantia discordantium astronomorum (1415) he quotes a long text from the first treatise attributed to al-Kindī (\$ 4-6). Pierre observes that astrologers have very divergent views about what constellation is related to what region or city on earth and he gives some examples of this divergence: « ex variis sapientum dictis pauca exempli gratia recitabo. Sicut ergo refert Jacobus Alkindi libro de iudiciis annorum mundi dicit Enoch qui et Hermes ». Follows the complete text of $\S 4-6 .{ }^{158}$ It is highly improbable that Pierre had himself a manuscript of Bate's translation. In De concordia he heavily relies upon Bate's lost commentary on Albumasar's De magnis

\footnotetext{
158 I use the magnificent edition of Johannes de Westfalia, Leuven c. 1477-1483, sig. ii2r-v.
} 
Shlomo Sela, Carlos Steel, C. Philipp E. Nothaft, David Juste \& Charles Burnett

coniunctionibus, as he himself acknowledges. ${ }^{159}$ Pierre must have found the long quotation from this very rare translation in that commentary. From the same lost commentary come also the other authorities that Pierre mentions after the 'Alkindi' text: "Preterea Abraham Avenasre de hiis sparsim multa loquitur in Ysagogis suis, quas vocatur Inicium sapientie, sed ultra hec in libro suo coniunctionum refert ita: Dicit Enoch primus quod Iupiter cum Cancro significat super terram Alaerat, id est Herachie, Saturnus vero cum Libra... » (cf. 'Olam I, § 56). ${ }^{160}$

I collated my edition of \$4-6 with the quotation in De concordia (as found in the edition): besides typographical errors most variant readings are found in the spelling of the names of cities and regions. Only in one case I wondered whether Pierre may have had a better reading:

II, §4:6-7 Leo uero cum Marte super illos qui morantur in climate septimo; Luna uero cum Virgine super partes Alsin] Leo et Virgo cum Marte super eos qui morantur in climate septimo. Luna uero cum Virgine super eos qui morantur in parte Alsin Pierre d'Ailly.

" et Virgo », however, is probably an error for "uero"; and the longer version " super eos qui morantur in parte Alsin » seems to have arisen from what was said before: "super illos qui morantur in climate septimo ».

So, Pierre only is an indirect witness of Bate's translation. After all, it is surprising that there still exists a manuscript of this rare text. The Vaticanus is most probably a direct copy made from a manuscript that belonged to Bate himself. One may even assume that the scribe not only found the 'Alkindi' translation in that manuscript, but also Bate's De diebus creticis, which follows, and even the other preceding texts, including Zael and Albumasar's De revolutionibus annorum closely related to the 'Alkindi' texts. I collated some pages of De diebus creticis and of the Fatidica of Zael with editions of these texts and had to conclude that the text in $V$ has very few particular mistakes. This shows not only the professional quality of the scribe but also that he may have used a very good exemplar.

159 See Elucidarium, c.19 (sig. ff2r): « Nota quod ibi [that is in his commentary on differentia I, De magnis coniunctionibus] dicit Henricus de Machlinia quod Albumasar magnam facit vim de signis orbium et dominiis eorum, necnon de consequentibus ad hoc ». On this lost commentary, see David Juste in STEEL et al. (eds.) The Astrological Autobiography, p. 48.

160 Pierre refers to 'Olam I as Liber Coniunctionum as does Bate himself. 


\section{II.1.2. Principles of the edition}

It is always difficult to edit a text that is based on only one manuscript - in this case a copy of the late fourteenth century. I have, however, the impression that the scribe of $V$ was very accurate and made few mistakes, like omissions. The editor's interventions are very limited. I compared the Latin text with the English version $(L)$ and indicated in the apparatus those variants that may indicate that the English was based on another Latin MS.

This is not a diplomatic edition where one follows scrupulously the peculiarities of a single manuscript. Punctuation and paragraphing are mine. For the spelling of the proper names I follow $V$. However, I do not follow the scribe in an occasional 'set' for 'sed' or 'velud' for 'velut'. I do not introduce diphthongs (ae or oe) and do not distinguish between $-u / v-$, using $-u$ - for both the vowel $-u$ - and the consonant $-v-$, while keeping $V$ - only for capitals. More difficult was a decision about the ending of words on -cio or -tio, -cia or -tia. It is often difficult to distinguish in $V$-t-from $c^{-}$, and for many '-tio' words an abbreviation is used ('oppositio' for instance). Of course, a scribe of the fourteenth century would write 'reuolucio, disposicio, significacio, inicia' and 'eciam' if he did not use abbreviations. I kept nevertheless these terms in their standard dictionary form 
Shlomo Sela, Carlos Steel, C. Philipp E. Nothaft, David Juste \& Charles Burnett

\section{II.2 Edition of the Latin Text \\ (Carlos Steel)}

\section{< I. ABRAHAM AVENEZRA: DE REVOLUTIONIBUS ANNORUM MUNDI > ${ }^{161}$ \\ < 1 . De corporibus supercelestibus >}

1. (1) $\left\{55^{\mathrm{r}}\right\}$ Inter sapientes non est discensio quin ${ }^{162}$ omnia generabilia colligata sint corporibus supercelestibus, quorum uirtus uniuersaliter in omnia influit inferiora. (2) Nam anime uiuentium omnium <sunt> sicut forme procedentes a motoribus orbium et lumine stellarum fixarum ac erraticarum. (3) Secundum autem quod planete maiores et propinquiores terre fuerint, secundum hoc magis apparebit fortitudo ${ }^{163}$. (4) Propter quod dicit Ptolomeus quod si planeta fuerit in inferiori parte orbis ecentrici siue in opposito augis, apparebit eius fortitudo super terram magis quam si fuerit prope augem sui circuli, et idcirco non est locus habitabilis in parte terre meridiana propter fortitudinem caloris Solis, quia maior est inter alias stellas que uidentur. (5) Concordati sunt etiam precipui sapientes quod anima humana colligata est orbi signorum in quo sunt stelle fixe. (6) Et hic est orbis octauus a terra. Suntque omnes stelle eius diuise in 48 ymagines, de quibus uiginti una uersus septemtrionem sunt ab orbe signorum et 15 uersus meridiem et 12 in orbe magno, qui est cingulum orbis signorum. (7) Vocauerunt quamlibet harum 12 partium siue diuisionum nomine ymaginis que propinqua est ei in orbe illo. (8) Luna uero et alii quinque planete aliquando sunt in media linea orbis signorum et aliquando egrediunt $\mathrm{ab}$ illa paucis gradibus ad dextram et etiam $\mathrm{a}<\mathrm{d}>$ sinistram. (9) Sol uero tantum seruat mediam lineam orbis illius semper.

\section{<2. De naturis planetarum >}

1. (1) Antequam autem de coniunctionibus planetarum sermo fiat, loquamur de naturis ipsorum. (2) Palam quidem est quod sapientes per rationes ostenderunt naturam stellarum non esse igneam, quia celum et quidquid in eo est compositum non est, sed est simplex, propter quod in se ipso permanet semper et non augetur nec minuetur neque transmutabuntur aliqualiter in se ipsis ille creature sublimes. Vnde Psalmista de ipsis loquens inquit: Statuit ea in seculum seculi.

2. (1) Queritur autem hic difficilis questio quare scilicet dixerunt sapientes iudiciorum astrorum quod Luna est frigida et Mars calidus qui totus est igneus. (2) Aliqui etiam dicunt: ista experti sumus et ita inuenimus quod hec stella

161 Titulum add. editor. Sequitur capitulum uel sequuntur capitula, sed non inueni plus supra textum $s c r$. $V$ liber Jacob Alkindi de reuolutionibus annorum mundi alio atramento scriptum mg. $\mathrm{V}^{2}$

162 prius quoniam sed exp. $V$

${ }_{163}$ prius fortune sed exp. $V$ 
calorem generat et illa frigus. (3) Ptolomeus uero dicit quod Luna est frigida et humida ob hoc quod est propinqua terre, a qua humiditas magna ad ipsam peruenit. (4) Dicit etiam quod Sol est nature calide et quia calidi est ascendere, idcirco Mars est calidus. Saturnus uero, quia remotus est ab aliis planetis, ob hoc est frigidus. Et quia Iupiter est in medio calidi et frigidi, ideo est temperatus.

3. (1) Dicit Iacob Alkindi quod 4 signa sunt initia reuolutionum tropicarum et quia calidum est actiuum, propter hoc dictum est quod Aries est calidus. (2) Calidum enim et frigidum actiua sunt. Et quando Sol est in directo signi Arietis, ipse est ascendens respectu habitationis nostre et tunc germinant plante et mouentur egritudines. (3) Et dixerunt quod signum Cancri est frigidum. Frigidum quoque est actiuum similiter.

4. (1) Propterea dixerunt alii quod ex proportionalitatibus sunt excepta iudicia astrorum. (2) Nam proportionalitas orbis Iouis ad orbem Solis et ad orbem Lune et ad terram est proportio amicitie. (3) Contrarium uero huius est de proportione Saturni et Martis. $\left\{55^{\mathrm{v}}\right\}$ (4) Est enim Lune sicut 12 et Veneris et Mercurii sicut 14 et Solis 18, Martis 20, Iouis 24 et Saturni 32.

5. (1) Veritas autem est quod lumen quodlibet generatiuum est caloris et quia corpus Lune minus est quam corpus terre, corpus uero Solis est maius terra 166 uicibus, idcirco est Sol caloris magni generatiuus. (2) Quia uero natura caloris parui, qui remissus est, laxatiua est et fluefactiua, ob hoc lumen suo calore, qui paruus est, augmentationem habet humiditatis ${ }^{164}$ et non ita Sol. (3) Venus etiam propinqua est nature Lune, quia lumen eius magnum est, et est etiam propinqua terre, propter quod ambe significatiue sunt pluuie. (4) Mercurius quidem, quia paruus est, consimiliter alteratur. Nam lumen eius paruum est. (5) Iupiter autem, quia maior est omnibus planetis post Solem et est remotus a terra, propter hoc generatiuus est caliditatis et humiditatis temperate que in natura uite. (6) Et quia Sol desiccatiuus est propter excellentiam caloris et Mars est magnus et orbis eius propinquus, ideo ${ }^{165}$ calorem magnum generat. (7) Et dixerunt quod hec est natura eius et ratio sue actionis uel operationis. (8) Saturnus uero quia remotus a terra, propter hoc lumen eius non est generatiuum caloris secundum proportionem temperamenti conuenientis homini, quamquam lumen per se generatiuum sit caloris. (9) Cuius exemplum est hoc quod dicunt sapientes medicine quod caro bouina frigida est; et uerum dicunt secundum quod comparatur ad corpus humanum. Est tamen calida secundum quod est caro.

6. (1) Quoniam autem inuenerunt naturam signorum per comparationem ad res inuentas super terram, dixerunt Arietem esse calidum et †siccum temperatumt,

164 humiditates $V$

165 prius satis sed exp. $V$ 
Shlomo Sela, Carlos Steel, C. Philipp E. Nothaft, David Juste \& Charles Burnett

ab eo similiter quintum ${ }^{166}$ et nonum,Taurum autem frigidum et siccum et signum Geminorum secundum figuram humanam calidum et humidum, et Cancrum frigidum et humidum, ut est aque natura. (2) Et non est necesse hic prolongare sermonem quia ueritas proportionis in aspectibus est, nec est in hoc discordia. Aries enim, Leo et Sagitarius calidi et sicci sunt, Taurus, Virgo et Capricornus frigidi et sicci sunt, Gemini, Aquarius et Libra calidi et humidi, Cancer, Scorpio et Pisces frigidi sunt et humidi. (3) Amplius concordati sunt omnes quod Luna est terre propinqua et super naturam nati significat secundum habitudinem loci sui et secundum quod alii ipsam aspiciunt. (4) Mercurius uero super discretionem rationis significat et super animam humanam, Venus autem, quia alte locata est, super appetitum continuandi speciem, Sol quidem sicut cor in humano corpore, in quo quidem corde anima auget calorem ${ }^{167}$; ob hoc ergo relatum est cor ad Solem. Superiores uero planete significare habent super uniuersalia. Saturnus quidem super gentem antiquam et regnum antiquum, Iupiter uero super gentem nouam et regnum nouum, sed Mars significans est bellorum et uictoriarum. Non uidetur autem accidere quod regna renouentur nisi per bella.

\section{<3. De coniunctionibus >}

1. (1) Cum autem coniunctiones omnes planetarum omnium considerauimus, nos inuenimus eas centum et 20 , quoniam de duobus sunt 21 , similiter est de 5 , et de 3 35 et ita est de 4 , de 6 uero 7 , et sunt omnes secundum numerum septenarii, multiplicant super numeros impares per duplicationem et non est aliquis numerus nisi 7 et post qui septenalis (?) sit. Coniunctio uero de 7 una est.

2. (1) Radix quidem autem significationum uniuersalium est secundum duos superiores planetas et principium coniunctionis eorum est in Ariete. (2) Et post 20 annos coniungentur in Sagitario et post alios 20 annos in Leone; $<\ldots>^{168}$ et ita fac<iunt> 12 uicibus aut 13. (3) Et hoc erit in 240 annis aut in 260 annis. (4) Et post signa ignea mutantur ad signa terrea secundum uiam et modum quem in igneis habuerunt. (5) Et post hoc mutantur ad signa aerea, post ea uero ad aquea. (6) Et coniunctio in triplicitate uocata ${ }^{169}$ est magna coniunctio. (7) Coniunctio uero 20 annorum $\left\{56^{\mathrm{r}}\right\}$ est minor coniunctio.

3. (1) Non est possibile homini minutum coniunctionis ipsorum inuenire propter tarditatem motus eorum. (2) Loca quidem enim planetarum inuenta sunt per instrumenta probationum, in quibus secunda designari non poterant. (3) Vnde sapientes iudiciorum astrologie sustentati sunt supra reuolutionem anni mundi et

166 quintum [idest Leonem] coni. David Juste mar(.)um $V$ ?

167 calorem conieci: m..erem $V$

168 lacunam indicavi, cf. 'Olam I, §8:3: « Et post 60 annos a coniunctione prima coniungunt se denuo in signo Arietis in quo inceperunt primo »

${ }^{169}$ vocata correxi (cf. « clepid » $L$ ): nota $V$ 
super ascendens in loco linee equalis siue medii mundi, amplius et super ascendens cuiuslibet loci secundum longitudinem eius et latitudinem, iuxta quod scriptum est in Libro Tabularum. (4) Porro Ptolomeus dicit quod ab hora coniunctionis luminarium uel oppositionis eorum que fuerit ante reuolutionem anni dependet iudicium ipsius anni et huic conmiscetur quolibet anno coniunctio ipsorum luminarium aut oppositio proximo precedens introitum Solis in signa mobilia. (5) Et est etiam necessarium cum omni studio scire gradum ascendentem in quolibet loco hora coniunctionis luminarium aut oppositionis eorum in mense in quo coniungentur duo superiores, et hec est ueritas.

4. (1) Et scias quod signum Iudeorum est Aquarius et Leo Christianorum, Sarracenorum uero Scorpio. (2) Dixerunt quoque experimentatores quod constellatio Sarracenorum est Venus cum Scorpione. Nam in termino Veneris fuit coniunctio secte Sarracenorum. (3) Plures etiam sapientum aspiciunt super coniunctionem Saturni et Martis qui accidit omnibus 30 annis in signo Cancri.

\section{< 4. De iudiciis annorum mundi >}

1. (1) Incipiemus ergo nunc loqui de iudiciis annorum mundi. (2) Et primo quidem inhibemus ne sustenteris super diuisiones que sunt 2000 annorum secundum gradus circuli neque super 2000 secundum numerationes signorum neque super 2000 secundum numerationes planetarum. (3) Nam hoc totum nichil est nisi cogitationis destructio nec est etiam proficuum alicui legere libros iudicatiuos super annorum decennios et centenarios et 2000rios. (4) Scire[s] debes quod iudicia mundi sunt res pluuiarum et anni famis et egritudinum et bellorum necnon mutationum regnorum.

\section{<5. De mansionibus Lune >}

1. (1) Et oportet quidem rememorari mansionum Lune significantium super pluuias necnon et mansionum siccitatem significantium (2) Et ponam figuram earum et nomina secundum linguam Arabicam.

2. (1) Prima mansio Alnethath, idest cornua que sunt Arietis, et sunt 3 stelle de magnitudine tertia sic deposite $\cdot$ : (2) Secunda ${ }^{170}$ mansio Albathin, idest uenter paruus Arietis, et sunt 3 stelle parue de magnitudine quarta :. (3) Tertia Althiri et sunt Plyades et est cauda Arietis; sex sunt ibi stelle de magnitudine quarta $: \because$ (4) Quarta Aldebaran et est stella clara et rubicunda de magnitudine prima $\cdots:$ : et est oculus Tauri. (5) Quinta Alhakaa ${ }^{171}$, Caput Geminorum, et sunt tres stelle parue inter duas claras $\because$ de magnitudine secunda. (6) Sexta Alhanaa iuxta Geminos et

\footnotetext{
170 pro mansione prima sicca $\mathrm{mg}$ scriba notavit, pro mansione 3 et 4 humida, pro 6 sicca, pro 7 humida, pro 9 sicca, pro 10,12,15, 16 et 17 humida

171 Alhakath $V$
} 
Shlomo Sela, Carlos Steel, C. Philipp E. Nothaft, David Juste \& Charles Burnett

sunt tres stelle in similitudine sagitte de magnitudine tertia $\because$ (7) Septima Aldarehen, idest brachium, et sunt due stelle clare iuxta Caput Geminorum inferius : (8) Octaua Alnatera, idest nasus Leonis, et sunt due ${ }^{172}$ stelle parue in similitudine nubis de magnitudine quarta $\therefore$ (9) Nona Altheraf, idest oculus, et est oculus Leonis et sunt 3 stelle parue $:$ et tertia inferior est occulta de magnitudine quinta. (10) Decima Algabra, idest frons Leonis, et sunt 4 stelle de magnitudine tertia et quarta :: (11) Undecima Alzebra ${ }^{173}$ et aliqui uocant eam Alcartan et est costa Leonis; sunt autem due stelle magna et parua honoris secundi et quinti : (12) Duodecima Alscarfa, idest cauda Leonis, stella una magna primi honoris. (13) Tredecima Allatua, sunt 4 stelle de magnitudine sexta et est superius una stella parua et clara :... (14) Quartadecima Alchemaah et est Alcimec Allahasel, idest inermis, et ratio est quod non habet lances; est autem stella clara primi honoris • (15) Quintadecima Algaphar, tres stelle parue de magnitudine quarta $:$ et est lingua Libre. (16) Sextadecima Alzabena, et sunt lances Libre, due stelle clare secundi honoris .. (17) Decima septima Alkalil, et est corona Capitis Scorpionis, et sunt tres stelle de magnitudine tertia ... \{56 $\left.6^{\mathrm{v}}\right\}$ (18) Decima octaua Alkalabe, idest cor Scorpionis, stella magna secundi honoris inter duas paruas lucidas ... (19) Decima nona Alxula, idest aculeus Scorpionis, due stelle quarti honoris et coniunguntur secum alie stelle parue (20) Vicesima Alnayn, sunt 8 stelle, 4 coniuncte ex una parte et 4 coniuncte ${ }^{174}$ $\mathrm{ab}$ alia parte, superius autem est una clara, et sunt de magnitudine tertia et quarta : (21) Vicesima prima Albalda et est in similitudine littere que apud Hebreos uocatur Heez subuerse, cuius pars superior posita est inferius et e conuerso, et sunt 6 stelle in forma arcus $\cdot . . . \cdot$ (22) Vicesima secunda Saadebach, et est hoc difficile scribere in lingua Hebrayca et significat eufortunium carnificis seu decollatoris, suntque tres stelle, una parua in medio duarum : (23) Vicesima tertia Saedeblac, et sunt due stelle, una quasi absorta a secunda et sunt due parue : (24) Vicesima quarta Saedealsaode, et sunt 2 stelle, una magna <et una parua,> et prope ipsas una parua .: (25) Vicesima quinta Saadealkabe, sunt 4 stelle quarum due impresse sunt insimul super duas que non tantum lucent sicut alie due :: (26) Vicesima sexta Alperaalaoul, idest urna aquarii, et sunt due stelle quarti honoris : (27) Vicesima septima Alperaue, idest urna posterior, et sunt due stelle urne aquarii meridionales : (28) Vicesima octaua Betnalhoz, idest uenter piscis, et sunt 7 stelle ordinate in similitudine corporis piscis suntque propinque orbi signorum.

3. Describam igitur tabulam ad sciendum que sunt mansiones et quot gradus quelibet contineat, et minuta similiter cum secundis. Correcta est hec tabula cuius distinctio est secundum octauam speram.

172 due $V$ quod non consentit cum figura sequenti quae quinque habet stellas; sex in Abraham Bar Hiyya

173 Aldebra $V$

174 coniuncte iteravit $V$ 


\section{Tabula mansionum lune ${ }^{175}$ correcta iuxta concordantiam philosophorum ${ }^{176}$}

1 Aries Alnelbaf ${ }^{177}$ idest trusio* siue cornua

2 Aries Albatin

3 Taurus Altari, idest Pliades

4 Taurus Aldebaran, idest Yades

5 Gemini Alhakaa idest cadens

6 Gemini Alhanaa ${ }^{178}$

7 Gemini Adraa

8 Cancer Alnath idest fugiens

9 Cancer Altarf ${ }^{179}$ idest expeditus siccus

10 Leo Algabeha idest frons

11 Leo Alzabra idest uirescens

12 Virgo Alzarfa ${ }^{180}$ idest comere

13 Virgo Alaaua idest mustela

14 Virgo Alchemah idest spica

15 Libra Algefar ${ }^{181}$ idest amarum

16 Libra Alzabena idest humida coniuncta

17 Scorpio Allzalil idest corona

18 Scorpio Alkiab idest siccus expeditus

19 Sagitarius Alxula idest disperditus

20 Sagitarius Alnayn idest delicie
12.51.26 temperata

25.42. 51 sicca

8.34.17 temperata

4.2.26.43 humida

4.17.9 temperata

17.8.34 sicca

7.30.0.0 temperata (+ humida)

12.51.26 temperata

25.42 .51 sicca

10.8.34.17 temperata (+ humida)

21.25.43 temperata

12.4.17.9 humida

17.8.34 sicca

30.0.0 temperata

15.12.51.36 temperata (+ humida)

16.25.42.51 humida

17.8.34.17 humida

21.25 .43 sicca

19.4.17.9 temperata (+ humida)

17.8.34 temperata (+ humida)

(secundum Hispalensem et Indorum tempora)

21 Sagitarius Alba<l>da idest terminus

30.0.0 temperata

175 luna $V$

176 nota quod scriba prius errorem fecit in numeratione 28 mansionum et postea quod scripsit delevit et in margine scripsit « iste numerus superius positus non valet quia erravi scribendo »

177 Alnebaf sed -1- s.v. V

178 halanaf $V$

179 altraf $V$

180 alzarta $V$

181 algepar $V$ 
Shlomo Sela, Carlos Steel, C. Philipp E. Nothaft, David Juste \& Charles Burnett

22 Capricornus Sadeldebac ${ }^{182}$ idest serpens

23 Capricornus Sadebalac idest gluciens

24 Aquarius Coodeakeode idest serpens clarus

25 Aquarius Cradealkade idest serpens siccus

26 Pisces Alpargor idest plaga sicca

27 Pisces A<l>praghenoth idest truncus fabe

28 Pisces Alhoz idest pisces
20.12.51.26 humida

25.42.51 temperata

8.34.17 temperata

21.25 .43 sicca

4.17 .9 sicca

17.8.34 humida

30.0.0 temperata

4. Nota quod sex sunt mansiones humide principaliter, secundum quod testatur Alkindus et illas ennarat Auenezre solum pro humidis, licet alique alie sunt humide mediocriter et sunt ille que hic sunt significate.

\section{<6. De anno solari >}

1. (1) Volumus autem nunc loqui de discordia que est inter tabulas antiquorum et posteriorum. (2) In hoc enim concordant antiqui quod annus solaris ueraciter contineat 365 dies et quartam diei $\left\{57^{r}\right\}$ et adhuc centesimam uicesimam partem diei, unde supra 365 dies integros est augmentum reuolutionis 93 graduum secundum propinquitatem. (3) Sapientes uero Persarum dicunt quod in illo augmento superexcrescent 15 minuta gradus supra illos 93 gradus. (4) Et Ptolomeus dicit quod ab illa quarta diei superexcrescente deficit una trecentesima pars diei que ualet gradum unum et 12 minuta. (5) Post Ptolomeum uero surrexerant sapientes multi in diuersis temporibus considerantes et probantes annum solarem minorem esse per diminutionem minus centesime uicesime partis diei ab illa quarta superexcrescente. (6) Et re uera mirabile est unde tantus error euenire potest. Nam in 60 annis accidet differentia unius diei inter ponentes quantitatem maximam anni et alios qui ponunt eam minimam. (7) Et quilibet experiri potest per umbram necnon et per instrumenta probationum.

2. (1) Alii uero sapientes dixerunt esse duos circulos paruos in Capitibus Arietis et Libre et secundum hanc uiam dixerunt aliquando ascensum fieri et aliquando descensum (2) Et de hac quidem secta discordant ${ }^{183}$ alii ab aliis. (3) Quidam autem dicunt motum illum usque ad 8 gradus pertingere. (4) Quidam uero magis se subtiliantes dicunt usque ad 10 gradus et duas tertias. (5) Indorum uero sapientes dicunt quod hic est motus stellarum fixarum, sed hoc nichil est. (6) Nam bene apparet quod Ptolomeus in tempore suo inuenit per instrumenta probationum Solem intrare caput Arietis cum dies equatur nocti in omnibus terre climatibus per

82 sahldebac $V$

183 prius dixeruntque sed exp. $V$ 
8 dies postquam hoc fuit secundum compotum Indorum. (7) Propter quod dixit in Libro figurarum quod 8 gradus addendi sunt ad sciendum figuram reuolutionis orbis signorum. (8) Sed hiis diebus est e conuerso quia Sol intrat Caput Arietis et equatur dies nocti antequam ipsum secundum compotum Indorum per nouem dies. (9) Vnde in anno coniunctionis duorum superiorum in signo Virginis erant 8 gradus.

3. (1) Detegam autem nunc partem huius secreti. (2) Scito quod inter istos sunt due secte. (3) Alii enim principium anni accipiunt cum puncto equinoxii, siue motus ascensus et descensus uerus sit siue non. (4) Alii autem reuersionem Solis accipiunt ad directionem stelle fixe, siue moueatur orbis stellarum fixarum in 100 annis per gradum unum siue in 66 annis et ${ }^{184} 8$ mensibus siue in 70 annis aut non sit motus alius orbi stellato preter illum qui est ascensus et descensus. (5) Et numerus uel quantitas motus Solis a puncto ad eundem punctum est equalis preter quod mouetur orbis Solis cuius centrum extractum est a centro terre, quia motus augis eius est equalis motui stellarum fixarum. (6) Et de hiis ponam exempla. (7) Dicit Ptolomeus quod motus stellarum fixarum in anno est una pars de 100 partibus gradus que ualent 36 secunda et huic correspondent 3 gradus et 36 minuta in anno de motu reuolutionis celi. (8) Et dixit idem quod de quarta diei in anno solari deest una pars 300 partibus diei unius que ualet unum gradum et 12 minuta de reuolutione orbis. (9) Et cum iste numerus subtractus fuerit de 3 gradibus et 36 minutis, remanebunt duo gradus et uiginta quatuor minuta. (10) Eritque secundum hoc annus solaris a stella fixa usque quo reuertatur ad eandem cum augmento partis unius de 150 in die. (11) Sapientes uero Sarracenorum dixerunt motum stellarum fixarum esse unius gradus in sexaginta sex annis, et huic correspondent quinque gradus et uiginti septem minuta secundum modum predictum. (12) Dixerunt autem quod in anno solari est diminutio unius partis de 115 in die et huic correspondent 3 et 13. Cumque hoc subtractum fuerit ab illo quod motui stelle fixe correspondet, remanebunt duo et quatuor decem. (13) Alii quoque magistri probationum, perscrutatores intimi, motum stellarum fixarum inuenerunt in septuaginta annis ${ }^{185}$ unius gradus esse, cui respondent quinque et nouem in anno, et secundum ipsorum compotum est diminutio anni solaris a quarta duo gradus et quadraginta quinque minuta. Cum uero subtrahitur hoc a numero supposito, remanebunt duo gradus et uiginti quatuor minuta, quemadmodum ponit Ptolomeus.

4. (1) Vniuersitas autem $\left\{57^{v}\right\}$ sapientum astrorum punctum equalitatis diei et noctis appellant Caput signi Arietis, ob hoc quod ymago Arietis secundum uisum est ei propinqua. (2) Et partiti sunt ipsi signa reliqua secundum ymaginationem ad instar huius. (3) Indorum uero sapientes orbem signorum partiti sunt iuxta quod

184 et correxi: in $V$

185 prius gradus scr., sed exp. et annis s.v.V 
Shlomo Sela, Carlos Steel, C. Philipp E. Nothaft, David Juste \& Charles Burnett

uisui apparebat secundum quod experimentati sunt et probauerunt in iudiciis <per> generationem post aliam, et est illa partitio secundum ymagines uisas in orbe signorum, hoc est secundum speram octauam.

\section{< 7. De coniunctione magna anni 1067 >}

1. (1) Et cum inspiceremus ad coniunctionem magnam que fuit in signis terreis, nos inuenimus Saturnum in uiginti octo gradibus signi Sagitarii anno Arabum 438, et inuenimus in illo anno uersus finem, uidelicet anni Christi 1047, Iouem intrasse modicum in gradibus signi Capricorni secundum diuisionem signorum, et erant ambo in ymagine Sagitarii. (2) Propter quod erat principium anni coniunctionis illius anno Arabum 459 in uicesima quinta die mensis quarti, secundum Christianos uero quartadecima die Martii anno Christi 1067. (3) Et cum uellemus scire gradum ascendentem in loco linee equalis, qui uocatus est Arym, (4) et iam scimus quod longitudo ${ }^{186}$ Winconie ab occidente est decem et nouem graduum et quod eius longitudo a medio mundi est septuaginta unius graduum, qui ualent quatuor horas et quadraginta quatuor minuta hore, et est motus Solis equalis in hiis horis et minutis, undecim[i] minuta et quadraginta secunda, (5) nos inuenimus motum Solis in annis collectis 1049 et in expansis 17 perfectis et erat motus Solis medius 11 signa, 14 gradus, 46 minuta, 40 secunda, et minuebantur ab hoc 11 minuta et 40 secunda, et erit residuum undecim signa, 14 gradus, 34 minuta, 0 in secundis. (6) Nos quoque respeximus ad sciendum locum augis Solis ad quem habendum oportebit subtrahere triginta tres annos a mille centum annis qui sunt radix augium. (7) Et est motus augis in illis triginta tribus annis uiginti octo minutorum. Subtraximus hec a loco in tabula scripta, qui est duo signa, uiginti sex gradus et quatuordecim minuta, et remanserunt ${ }^{187}$ duo signa uiginti, quinque gradus et quadraginta sex minuta. (8) Et erat equatio Solis unius gradus, quinquaginta octo minuta et quadraginta octo secunda ${ }^{188}$. (9) Minuebamus hoc a principio Arietis et erat residuum 11 signa, 28 gradus, 1 minutum, 12 secunda. (10) Ab hoc quoque substraximus numerum suprapositum qui prouenit ex annis collectis et expansis et remanserunt 13 gradus, 27 minuta, 12 secunda. (11) A quo etiam subtraximus hoc quod in 13 diebus de motu Solis inuenimus et erat residuum $0.34 .2^{189}$. (12) Huic quoque secundum motum Solis correspondent 19 hore, 34 minuta et erat hec anni reuolutio in loco linee linee equalis [per 33 gradus et 30 minuta $^{190}$ ] et est gradus ascendens 25 et 24 minuta signi Arietis fuitque introitus Solis in Caput Arietis in hoc loco, qui est Winconia, per 14 horas et 50 minuta hore post medietatem diei et erant fractiones ille quinque sexte unius hore, que sunt 10 minuta, et hoc erat in

186 longitudo: latitudo s.v. $V^{2}$

187 remanserint $V$

188 secunda correxi: minuta $V$

189 34.24: in aliis $48.13 \mathrm{mg}$. $V$

190 per-minuta] delenda cens. Nothaft super -s et 30 signa expunctionis hab. $V$ 
nona hora noctis secundum 312 gradus ascensionum terre et signum ascendens 9 gradus et 43 minuta signi Capricorni. (13) Et sunt loca planetarum, Solis scilicet 0.0.0, Lune 10.22.28, Capitis Draconis 5.11.30.14, Saturni 5.14.55 qui erat retrogradus, Iouis 5.2.1 retrogradi similiter, Martis 0.14.26, Veneris 0.7.15 ${ }^{191}$ Mercurii 11.9.7. (14) Et hic est locus Saturni et Iouis in hora coniunctionis eorum secundum tabulas quas ego composui: Saturni 5.12.23.17, locus eius equatus 5.18.51, Iouis 5.18.22.46, locus eius equatus 5.18.51, Solis 5.18.54.41, locus eius equatus 5.16.57. (15) Equaui etiam loca planetarum secundum uiam compositionis Albategni et Almamoni, Alzophi, Almazkar, quia inter eos est discordia de loco augis Solis ${ }^{192}$ et hoc ideo est quia non est possibile inquisitorem scire locum augis nisi per instrumenta. (16) Et in hoc est difficultas $\left\{58^{\mathrm{r}}\right\}$ magna quia non potest fieri instrumentum in quo secunda possunt distingui. Et secundum quod multiplicantur anni, possibile est secunda excrescere ad quantitatem sensibilem. (17) Inueni quoque coniunctionem ipsorum in die qua coniunctus est Sol cum eis per duos dies, uidelicet post coniunctionem Saturni et Iouis, in uno gradu, uno quoque minuto, et erat hoc quinque diebus perfectis de mense Septembris anni 1067 secundum annos ${ }^{193}$ Christianorum. (18) Et hoc est secundum annos Sarracenorum post uiginti tres dies mensis Zoal, qui est mensis decimus in numero ipsorum anni 459 a principio regni ipsorum. (19) Et hec sunt loca aliorum planetarum in die coniunctionis illius: Martis quidem 4.7.13, Veneris 4.9.5, Mercurii 6.12.25, Lune quoque 3.10.12 et erat Caput Draconis prope locum eius in die oppositionis. (20) Et necesse quidem habui scire oppositionem Lune cum Sole que fuit ante coniunctionem illam uicesimasexta die Augusti, motus Solis medius 5.11.1.26, motus Lune medius 11.7.50.24, portio uero Lune in media die illa 7.2.39 52. (21) Et erat oppositio in octo gradibus 59 minutis, uno secundo signi Piscium. Et locus Capitis Draconis in hora oppositionis 5.6.50.48. Et non erat latitudo Lune nisi undecim minutorum et propter hoc illud quod significat est perfectum. (22) Et ascendens in Winconia $18^{194}$ gradus 7 minuta Libre et in linea equali $6^{195}$ gradus 5 minuta signi Capricorni.

191 0.7.15 V (sed 0 videtur correcta): 17.16 Aris L melius esset 1.7.15 ut David Juste opinatur

192 Solis correxi: Iovis V

193 annos iter. sed corr. $V$

$19418 \mathrm{~V}: 10 \mathrm{~L}$

195 6. $V$ (sed .1. s.v.) $: 10 \mathrm{~L}$ 


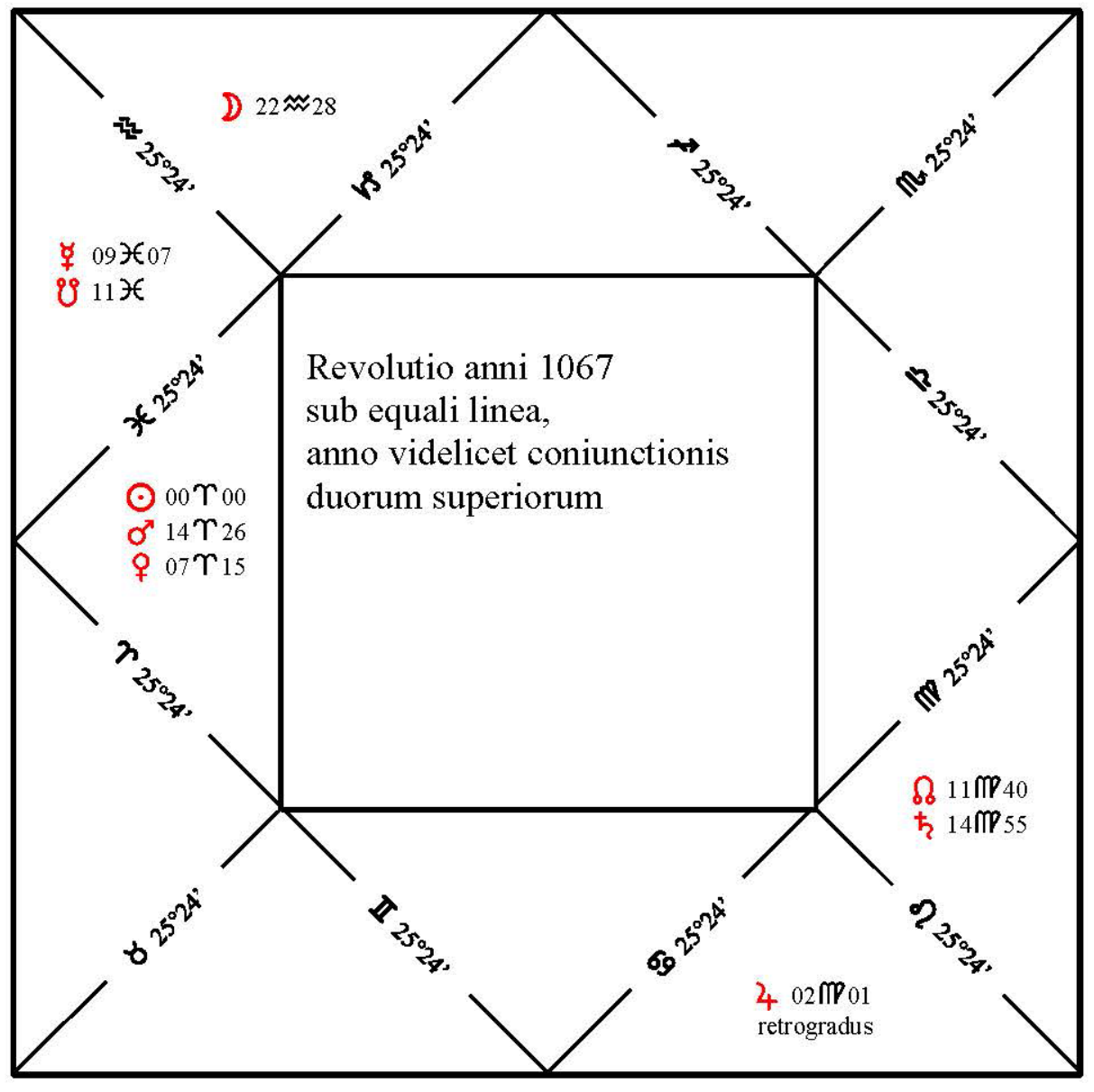

Horoscope 1 


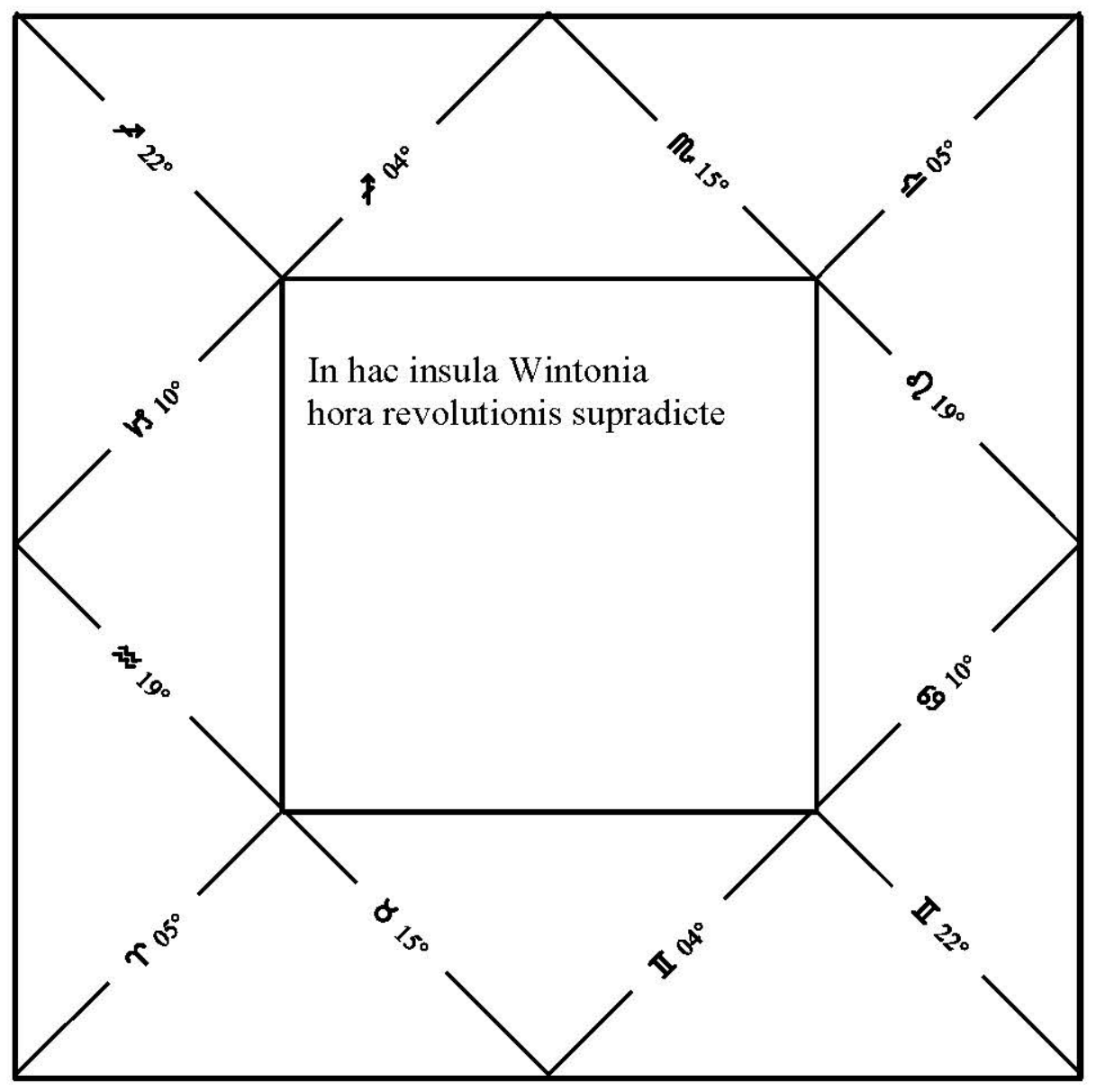

Horoscope 2 


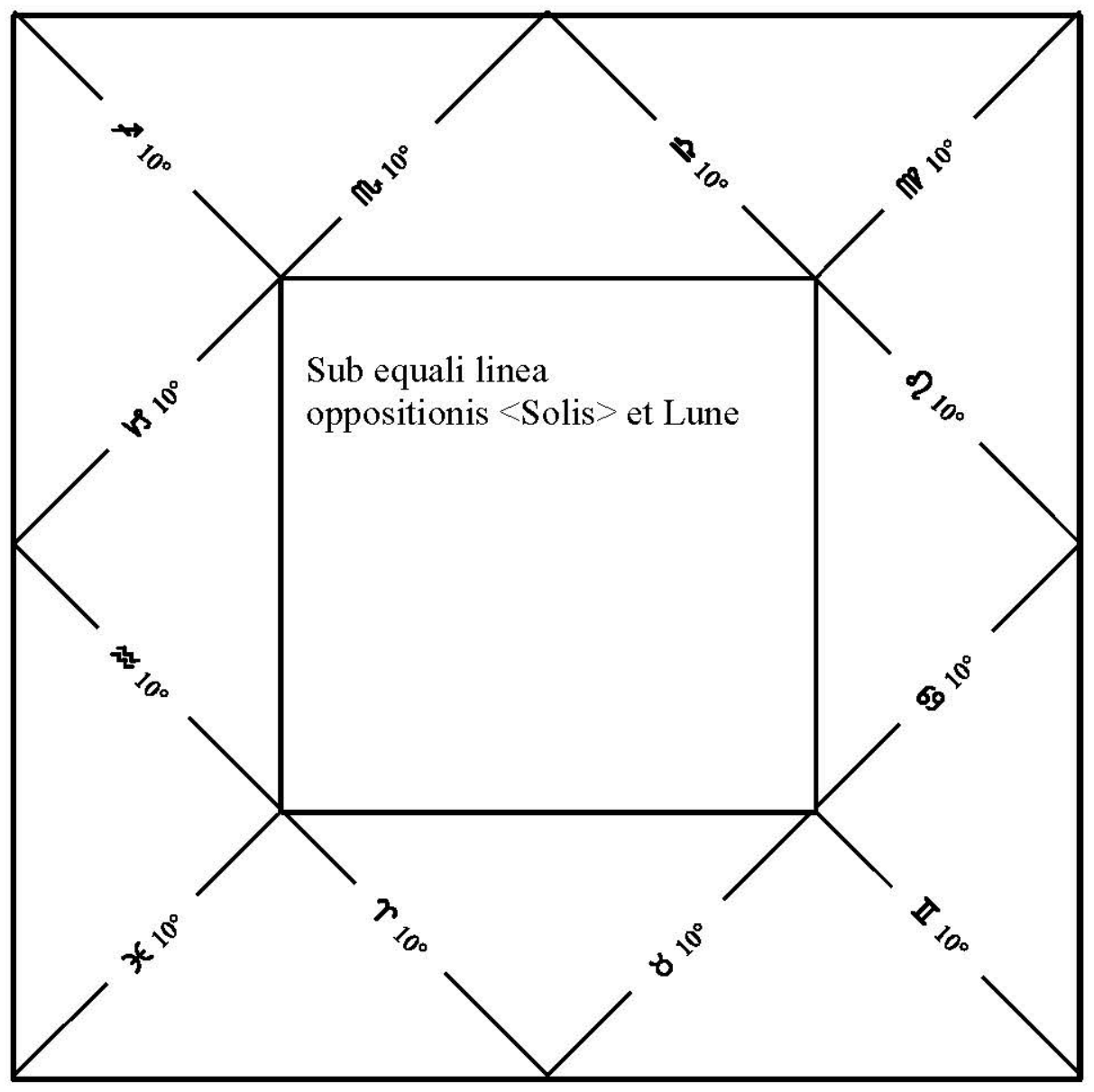

Horoscope 3 


\section{< II. ALKINDI (?): LIBER DE IUDICIIS REVOLUTIONUM ANNORUM MUNDI, TRACTATUS PRIMUS $>>^{196}$}

1. Dixit translator: Interpretabor quidem nunc tractatum unum ex Arabico in Hebraycum ydeoma de iudiciis annorum mundi quem collegit Iacob filius Ysaac Alkindi. Et hoc est initium sui tractatus.

2. (1) Quia concordati sunt omnes astrorum iudices quod uniuersalium iudicia seu communium dependent a coniunctione duorum superiorum, a principio incipiam ${ }^{197}$ coniunctionis eorum in signis triplicitatum. (2) De signis enim igneis mutantur ad signa terrea. (3) Et tu debes aspicere ad figuram dispositionis orbis signorum. (4) Et scito signum coniunctionum cuiuslibet ${ }^{198}$ de partibus terre seu regionibus. (5) Et $\left\{58^{\mathrm{v}}\right\}$ debes etiam attendere secundum quod melius poteris ad sciendum gradum ascendentem in hora introitus solis in signum seu figuram Arietis, et hoc tempus ${ }^{199}$ subtrahendum est de tabulis, que facte sunt secundum uiam probationis ${ }^{200}, 8$ gradus, quadraginta quinque minuta et triginta secunda. (6) Et intrat Sol ymaginem signi Arietis inter uicesimum secundum diem Martii et uicesimum tertium. (7) Et equa planetas ad illum diem et horam et subtrahe numerum ${ }^{201}$ supradictum de loco Lune et a locis reliquorum quinque planetarum. (8) Equa etiam uel precisius poteris coniunctionem luminarium seu oppositionem, utra eorum propinquior fuerit antequam Sol intrat principium signi Arietis in anno quo coniunguntur duo superiores. (9) Et considera signum gentis cuiuslibet et etiam signum cuiuslibet terre seu regionis qualiter scilicet se habeant ad signum coniunctionis et ad signum ascendens in hora coniunctionis Solis et Lune uel oppositionis eorum. (10) Et aspice similiter dispositionem planetarum et dominum signi gentis cuiuslibet et ciuitatis. (11) Est quoque necessarium ualde notitiam habere signi ascendentis in principio anni ut sciatur quis planeta est in angulo uel in succedenti angulum aut in ab angulo cadente, et qualiter se habeant planete ad Solem.

3. (1) Et semper compara Solem regibus et principibus ${ }^{202}$ magnis aut magnatibus, Saturnum uero antiquis et terre cultoribus, et Iouem iudicibus et sacerdotibus, Martem uero militibus et belligeris necnon et cyrurgicis, Venerem mulieribus et medicis et eunuchis ${ }^{203}$, Mercurium uero sapientibus, scribis et mercatoribus, Luna $<\mathrm{m}>$ uero toti uulgo communiter.

96 Alius tractatus Alkindi add. mg. $V^{2}$

197 incipiam correxi: inquam $V$

198 cuiuslibet correxi: cuius est $V$

199 tempore $V$

200 probationis $m g$. add. $V$

201 numerum: month (mensem ?) L

${ }^{202}$ potentibus $m g . V^{2}$

203 eunuchis conieci: inmisacis (?) V 
Shlomo Sela, Carlos Steel, C. Philipp E. Nothaft, David Juste \& Charles Burnett

4. (1) Dicit Enoch, qui est Hermes, quod signum Arietis et Iupiter significant super partes Alaerac idest Eracleam, que est in terra Persarum, et ibi est Babilonia et Baldac; (2) Saturnus uero cum signo Libre super Romam et terras Christianorum uel non circumcisorum; (3) et Sol cum signo[rum] Aquarii super terram Iudeorum, idest Iudeam, usque ad Egyptum; (4) et signum Capricorni cum Mercurio super terram Dalhenam, idest Indorum; (5) et Venus cum Scorpione super terram Cumanorum, idest Arabum; (6) Leo uero cum Marte super illos qui morantur in climate septimo; (7) Luna uero cum Virgine super partes Alsin.

5. (1) Sapientes quoque Babiloniorum locuti sunt super partes terre. (2) Et dixerunt quod Aries significat super Persiam et Ardenagaam et Galaciam et Philistin, idest Palestinam, et Babiloniam et Balgaam et Almussal, hoc est Assiriam; (3) Taurus super Assabeham et Mea et Caberas et Aziam Minorem et super montes Deberaz (et montes sunt magni ualde); (4) Gemini super Galaan et Margaan et Cebarastaan et Armeniam Maiorem et Adarnegerdaan et Bargan et Camaniaam et Alarquia et Abarabalini et super angulum Occidentis et Egypti et super terram Barca; (5) Cancer super Affricam et Philestin, idest Palestiniam, Parnessie et super terram Christianorum idest non circumcisorum et Romaniam et Armeniam Minorem et Orientem de Corasten et Marcam et Baldac et Alaerac; (6) Leo super terram Altmedioserath, idest terram Turcorum, et Bascetar et Ytaliam et Romam et Britanniam Maiorem et super terram Hemes et Damascum et regnum Assura et Atupa et Albostera et Gog et Magog; (7) Virgo super terram Constantinopolitanam et Acristas et mare Palestinorum et Canaan et Segastaan; (8) Libra super terram Cahara et Segastaen Caherastaen et Miscemat et Timas, que est maxima ciuitas in terra Indorum, et super flumen Egypti et terram Ethiopie; (9) Scorpio super Alhagan et Emal et Tanega et Harbar Samara et Soria et Soaz et Canat et Caana et Thersoz Aendaria et Placania et Cuin et Allaaz et Aabdaeri et Arabes; (10) Sagittarius super Alumin et Serdaniam et Hispaniam et Ceciliam et Arabiam antiquorum; (11) Capricornus super Indiam et Alchoz et Metharen $\left\{59^{\text {r }}\right.$ et Alsoz ${ }^{204}$ et Aaraquia et Mecarmoniam, idest Macedoniam, et Halaohaz et Ethiopes et flumen Maheraen, idest Egipti, et Scifalbehar et Amahen et Alerchenaz usque ad terram Alsin; (12) Aquarius super Assiriam Notam et Ballac et Sceaz et Bascea et Lonia et Aroquia et Assia et super terram Egipti cum sibi participantibus in terra Persie; (13) Pisces super Lactabia, que est Anglia secundum aliquos, et Ballac et Asania et Heurenia et Nicaz et Lascemoperaz et Paresalia et terram Altin et Gangaen et mare rubrum et elegit sibi Alimen, hoc est Mare Scena, et Malamonia. Item significat super terram Ethiopie et super Alexandriam et participant<es $>$ terre Christianorum, idest non circumcisorum.

204 alsoz s.v. $V$ alidez a.c. 
6. (1) Baldac ${ }^{205}$, idest Baudas, est in quarto climate cuius signum est uicesimus quartus gradus Cancri. (2) Et similiter est Iherusalem, sed eius signum est decimus nonus gradus Leonis. (3) Signum Egipti est Capricornus, Kartaginis est Gemini, Toleti Virgo, Granate Cancer, Hispalis Pisces, Balencie Scorpio, Cesarauguste Aries, Pisarum Aquarius, Luce Cancer, Persie et terre Siri Virgo cum Luna, climatis septimi Leo cum Marte terre de Meka usque ad Egiptum Scorpio cum Venere. Hec quidem igitur inuenta sunt secundum experientiam euentuum magnorum.

\section{< III. ALKINDI (?): LIBER DE IUDICIIS REVOLUTIONUM ANNORUM MUNDI, TRACTATUS SECUNDUS >}

1. (1) Dixit itaque translator: Transferam ex Arabico tractatum nobilem quem collegit Jacob filius Ysaac Alkindi qui sapiens erat in omnibus ualde scientiis, modis et speciebus habuitque librorum copiam. (2) Et hic dixit quod de sermonibus antiquorum accepit sermones ueraces in rebus coniunctionis Saturni et Iouis. (3) Et ipse locutus est de bellis et pluuiis et de annis caristie et uniuersaliter de accidentibus mundi. (4) Et hoc est initium sui tractatus.

2. (1) Considerandum est semper ad principium anni coniunctionis in triplicitate[m], quia non est diuersitas siue sit triplicitas ignea siue terrea aut aerea aut aquea. (2) Et considera cum omni precisione ad sciendum gradum ascendentem sub equali linea, ubi medium mundi est, in hora coniunctionis luminarium uel oppositionis eorum que fiunt antequam Sol ingrediatur initium signi Arietis, quia hoc est principium reuolutionis anni mundi uel orbis. (3) Scito etiam signum reuolutionis et similiter signum ascendens cuiuslibet loci in hora coniunctionis uel oppositionis et in hora reuolutionis anni et signum ascendens in quolibet loco uel qualibet ciuitate, adhuc et locum Lune cum precisione, quia necessarium quidem est scire gradum reuolutionis anni ad sciendum qui planete sunt in angulis aut in succedentibus angulos uel in cadentibus ab angulis et quomodo se habeant ad Solem et qualiter etiam eis est ex parte dignitatum in locis suis et si sunt in signis nature sue similibus uel in contrariis, adhuc et quod est signum mundi et quis sibi preest qui aspiciat alium gradum ascendentem a loco Lune et illum qui aspicit locum fortunatum uel infortunatum secundum naturam stellarum, quando perueniet ad ipsum directio uel secundum motum planetarum ad locum stelle fortune uel infortune secundum naturam suam uel ad ipsorum radios secundum gradus equales.

205 Baldic $V$ 
Shlomo Sela, Carlos Steel, C. Philipp E. Nothaft, David Juste \& Charles Burnett

3. (1) Dicit Messehallah ${ }^{206}$ : Semper debet duci uel dirigi gradus ascendens ad sciendum esse generis illius regum ${ }^{207}$ et similiter Luna, domus uero decima ad sciendum esse regum. (2) Et dicit etiam quod Sol habet significationes super reges. (3) Quod si est infortunatus Sol et Iupiter, descendet infortunium super regem Alerach. (4) Et si Sol est infortunatus cum Saturno, ueniet infortunium super regem Indie. (5) Et si Sol cum Marte, ueniet infortunium super regem Alterach, id est Turcorum, et super dominum siue principem septimi climatis. (6) Et si Sol cum Venere, ueniet infortunium super Arabum regem. (7) Et si Sol cum Mercurio, ueniet infortunium super regem Romanorum, idest Christianorum. (8) Et si Sol cum $\left\{5^{v}\right\}$ Luna, erat infortunium commune regibus et subiectis suis omnibus.

4. (1) Dixit Albumasar: Considerare debes quolibet anno ad signum profectionis a signo coniunctionis et gradu secundum gradus equales. (2) Et aspice si erat in principio coniunctionis aliquis aspiciens signum profectionis aut ${ }^{208}$ in hora reuolutionis anni mundi et da cuilibet gradui duodecim dies et dimidium et sextum unius diei. (3) Posuit autem ipse exemplum signum profectionis ab $8^{\circ}$ gradu Libre usque ad octauum gradum Scorpionis. Et est Iupiter in duodecimo gradu Libre et Saturnus duo gradus triginta minuta signi Scorpionis. (4) Debes ergo scire quod quelibet regio siue ciuitas cuius signum est Libra fortificabitur hoc anno, si in principio coniunctionis et in reuolutione anni similiter Venus fortunata fuerit, et e contrario erit res, si fuerit infortunata; et si in coniunctione fuerit boni esse et in reuolutione mali, erit defectus aliquantulus a bono; et si in coniunctione fuerit mali esse, in reuolutione uero boni, erit defectus aliqualis a malo. (5) Et quia longitudo est quatuor graduum, eueniet bonum cuilibet loco cuius signum est Libra post quadraginta nouem dies. (6) Et proueniet profectio ad locum Saturni post decem menses, et erit significatio super infirmitates, fluxus uentris aut constipationes ${ }^{209}$; et significabit etiam hoc super bella, quia Saturnus est in domo Martis et eius termino.

5. (1) Dicit Bennekha Indus: Attendendum est semper ad fortitudinem duodenarie gradus ascendentis. In loco enim in quo perficietur numerus signorum erit fortitudo illius ad quam intrasti, in signo uidelicet in quo terminabitur numerus erit eius gradus. (2) Gradus reuolutionis anni est 18.30 signi Cancri. Tunc ergo gradus duodenarie perueniet ad duodecimum gradum Aquarii. (3) Si igitur dispositio stellarum fortunata fuerit, eueniet bonum cuilibet loco cuius signum est Aquarius, et e contrario si mala. (4) Debes etiam attendere ad signum profectionis. Et similiter attende si remouetur aliquod boni uel mali secundum dispositionem stellarum respectu cuiuslibet loci cuius signum est signum profectionis. (5) Et scito

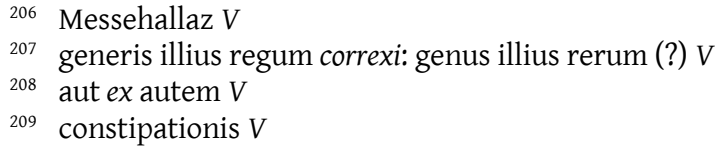


quod Saturnus significat regnum antiquum ${ }^{210}$ uel precedens, quod scilicet fuit ante principium coniunctionis triplicitatis. Et Iupiter significat super regnum <nouum > siue presens.

6. (1) Considera quoque in coniunctione ipsorum quis superemineat alteri. (2) Nam ille qui propinquior fuerit augi sui parui circuli hic preest alii et hoc scire poteris per argumenta ${ }^{211}$ Saturni et Iouis equata. (3) Debes etiam aspicere quis eorum propinquior fuerit augi circuli ecentrici et hoc quidem scire poteris per centra equata. Qui enim propinquior fuerit augi optinebit. (4) Debes quoque considerare ipsorum latitudines. Nam ille cuius latitudo sinistra fuerit uincet illum qui in linea signorum fuerit. Et ille qui in linea signorum fuerit uincet illum qui est uersus meridiem. Et si ambo sinistri sunt, uincit ille cuius latitudo sinistra maior fuerit. Et si ambo meridionales, uincet ille cuius latitudo est minor. Et si ambo in linea signorum, uincet Saturnus quia superior est.

7. (1) Rursum attendere debes ad fortitudines ipsorum secundum dignitates suas in loco coniunctionis, ut est dignitas domus, exaltationis, triplicitatis, termini et faciei, quis etiam ipsorum presit in reuolutione anni super signum ascendens in quolibet loco et super locum Solis et locum Lune et locum luminarium coniunctionis uel oppositionis eorum que precessit introitum Solis in Arietem, adhuc et locum partis fortune.

8. (1) Item dicit Messehallah: Considerare debes in qualibet reuolutione planetam orientalem a Sole, quia hic est particeps dominationis super annum. (2) Quod si fuerit in aliquo angulorum gradus aspectu aspicientis in quolibet loco, tunc erit fortitudo maior. (3) Quod si fuerit occidentalis a Luna, tunc erit fortitudo eius magna ualde.

9. (1) Debes etiam semper aspicere quis presit super quinque loca dignitatum in hora coniunctionis uel oppositionis luminarium precedentis introitum Solis in Arietem. (2) Si dederit ille fortitudinem suam planete superiori, iudicare debes secundum naturam stelle fortitudinem recipientis. (3) Debesque commiscere naturam dignitatum cum natura $\left\{60^{r}\right\}$ planete secundum domum et signum in quo est receptor fortitudinis. (4) Et si planeta recipiens fortitudinem fuerit retrogradus, reddet illam fortitudinem illi planete qui eam dederit. (5) Et consimiliter est si fuerit sub radiis Solis ad 15 gradus.

10. (1) Dixerunt quoque sapientes Indorum quod inspiciendum est semper ad uiginti octo mansiones Lune in qualibet anni reuolutione, hora coniunctionis uel oppositionis luminarium precedente Solis introitum in punctum in quo dies equatur nocti; et eodem modo faciendum est in mense quolibet. (2) Debesque

210 antiquum s.v. $V$ antiquorum a.c.

211 augmenta $V$ argumenta s.v. $V^{2}$ 
semper pro radice ponere coniunctionem <uel> oppositionem luminarium precedentem initium reuolutionis anni in quo coinunguntur superiores; nam quidquid per hoc significatur est generale siue commune. (3) Et reuolutio anni in quo accidit coniunctio de uiginti annis significat super particularia, reuolutiones quoque annorum singularium super particularia particularium. (4) Amplius et reuolutiones mensium significant super particularia particularium ipsorum singularium.

11. (1) Dixerunt etiam considerandum esse quis presit reuolutioni anni. Nam hic est dominus signi profectionis aut dominus termini directionis a loco coniunctionis magne aut dominus reuolutionis anni uel per aspectum uel per directionem. (2) Si inquam Saturnus dominus fuerit aut Venus aut Mercurius uel Luna, erit annus pluuiosus cum multitudine pluuie, et multo fortius si fuerit dominus ille in signo aqueo uel in signo super aquam significante, ut est Aquarius et finis Capricorni - nam ibi est effusor aque prior et posterior -, uel signum Leonis ubi est figura nauis. (3) Quod si scire uolueris utrum in principio anni erit pluuia aut in fine, respice locum Veneris in hora introitus Solis in signum Libre. (4) Si inquam sub radiis [suis] Solis fuerit et occidentalis, augmentabitur pluuia in prima medietate anni et in secunda medietate minuetur. (5) Si autem uisa fuerit Venus et orientalis, erit pluuia modica in prima medietate anni et e contrario in secunda.

12. (1) Semper autem est attendendum ad claues Lune duodecim. (2) Prima est hora coniunctionis Solis et Lune, secunda est cum distat a Sole 12 gradus, tertia 45, quarta 90 , quinta 135 , sexta 168 , septima 180 , octaua 192 , nona 225 , decima 270 , undecima 315, et duodecima 348.

13. (1) Mansiones quoque Lune significantes humiditatem sex sunt et sunt iste: 4 Aldebaran, 12 Alsarpha, 16 Alsabenen, 17 Alkalil, 22 Eseazaldabach, 27 Alpreaguealkaar. (2) Et mansiones sicce sunt sex et sunt iste: 2 Albatin, 6 Alhanae, 9 Alteraf, 18 Alkelaue 25. Sceazalkabia, 26. Alperagueallaol. (3) Alie uero mansiones sunt temperate siue mediocres. (4) Et tu poteris etiam habere notitiam mansionum hoc modo. Considera in qua mansione uideatur Luna in quolibet mense et minuatur semper hoc tempore a loco Solis et Lune et similiter a locis aliorum planetarum nouem gradus equales ad sciendum dispositionem ${ }^{212}$ siue figuram celi stellati, et debes incipere numerum ab Alnethai idest Alsaris et sunt cornua Arietis.

14. (1) Omnium quoque antiquorum et posteriorum concors est sententia quod quilibet planeta coniungitur alii planete aut aspicit ipsum quocumque aspectu fuerit quamdiu ad aspectum eius uadit. (2) Sed in hoc loco dissentiunt sapientes astrorum, quia aliqui dicunt quod hoc erit cum inter eos fuerit minus sex gradibus. (3) Alii autem dixerunt hoc esse secundum quantitatem graduum splendoris

212 dispositionem: disposicion of the Mone $L$ 
stellarum. (4) Nam splendor Saturni et Iouis est nouem gradus et Martis per se octo, Veneris et Mercurii septem. (5) Alii quoque dixerunt quod aspectus est perfectus si sextilis fuerit ut sit sexaginta graduum ante uel retro et peruenerit ad hunc numerum. (6) Et planeta inferior qui dat suam fortitudinem planete superiori, adhuc est in termino in quo fuit in principio uel prius. $\left\{60^{\mathrm{v}}\right\}$ (7) Nam contingere potest quod aspectus sit perfectus et uadat superior ad alium superiorem sibi propinquum si directus fuerit. (8) Et si sit retrogradus, eueniet aliquando quod radius uel aspectus sit perfectus in termino in quo non erat prius. (9) Et hoc contingit etiam in stellis cum superior sit uelox in cursu suo et inferior tardus. (10) Porro ueritas huius est quod aspectus minorari debet cum incipit inferior esse $\mathrm{sub}^{213}$ splendore superioris in coniunctione non in aspectu. (11) Et non numera lucem siue splendorem cum principio splendoris sed corpus cum corpore, numerum cum numero splendoris siue lucis stelle superioris, et quando peruenerit ad splendorem ueraciter secundum numerum sexaginta graduum, erit in aspectu sextili ante uel retro; et secundum numerum nonaginta graduum in quarto aspectu et secundum numerum centum uiginti graduum in trino; et secundum numerum centum octaginta in aspectu opposito. (12) Et erit tunc fortitudo aspectus in uigore maximo; nam tunc exibit ad opus.

15. (1) Messehallah dicit: si fuerit receptor fortitudinis in signo mobili, dabit ipse quasi numerum dierum. (2) Et hoc idem generale est quod signa mobilia festinationem significant, fixa uero permanentiam, [et] communia uero mediocritatem. (3) Radix scilicet pluuie omnium supradictorum est quod domus luminarium opposite sunt domibus Saturni. (4) Cum ergo in hora coniunctionis uel oppositionis eorum fuerint cum Saturno uel in eius aspectibus, significabunt obscuritatem aeris et pluuiam magnam. (5) Et commisceas dispositionem mansionum ${ }^{214}$ Lune cum predictis. (6) Iupiter quoque cum Mercurio uentos significat, Venere etiam in coniunctione cum Marte exeunte uel in eius radio ${ }^{215}$ siue splendore. (7) Considera si Mars occidentalis fuerit aut in signis aqueis, quia hoc pluuiam significat et coruscationes magnas et tonitrua. (8) Aspice similiter Lunam in hora coniunctionis. Si ipsa inquam Luna tunc aut in quarta sequente aut in oppositione coniuncta fuerit planete uel in eius aspectu preter illum qui est Solis, significabit hoc serenitatem aeris usque ad proximam quartam sequentem. (9) Debes etiam aspicere angulos in quolibet loco. Nam si pluuie significator in aliquo angulorum illius loci fuerit, ibidem fortitudo pluuie manifestabitur. (10) At si in domibus intermediis fuerit, inter ipsas inquam et ascendens, in aspectus ligatione, ${ }^{216}$ erit etiam pluuia modica, et si in cadentibus, non erit.

13 sub ex in corr. V

214 mansionum $m g$. add. $V$

215 radio: in al' aspectu $\mathrm{mg}$. not. $V$

216 legatione $V$ ligation, id est in byndinge $L$ 
Shlomo Sela, Carlos Steel, C. Philipp E. Nothaft, David Juste \& Charles Burnett

16. (1) Sapientes quoque Persarum dixerunt: Cum Venus, Luna et Mercurius in mansionibus Lune humidis fuerint, significat hoc pluuiam magnam; cum reuolutio anni, significauerit annum pluuiosum in die coniunctionis eorum, aut cum peruenerit ad aspectum in ${ }^{217}$ uno gradu [aspectum], tunc erit pluuia et magis erit si Luna fuerit in aliqua suarum clauium duodecim secundum quod prius explanaui.

17. (1) Rememorabor autem nunc sermonis Ptolomei sapientis qui dixit quod semper manifestabitur fortitudo planete secundum naturam eius cum fuerit in linea orbis signorum et fuerit directus. (2) Si autem septemtrionalis fuerit, erit fortitudo eius magna, et si meridionalis, minuetur eius fortitudo. (3) Quod si in auge fuerit, non manifestabit suam fortitudinem nisi modicum (4) Et si in opposito augis fuerit, tunc fortitudinem suam manifestabit multum. Sapientes uero Indorum contrarium dixerunt. (5) Ego autem dico quod utrorumque sermo uerus est, nam omnis res corporea, ut est pluuia et frigus et calor, se habet in esse suo iuxta sermonem Ptolomei, sed in rebus anime, ut est exaltatio et fortitudo, uictoria et dignitas erit iuxta sermonem sapientum Indorum.

18. (1) Nunc quoque dabo tibi communem regulam et generalem ad sciendum esse frigoris et caloris, humiditatis et siccitatis. (2) Considerabis enim semper ad Saturnum et Iouem, secundum quod se habuerint circuli superioris in figuris. Nam Saturnus significare habet super tempus in sua totalitate, Iupiter autem super annum. (3) Considerabis inquam horam introitus Solis in capita signorum mobilium et aspice si fuerint duo superiores in signis $\left\{61^{\mathrm{r}}\right\}$ calidis, quia tunc erit quarta illa anni calida, et si in frigidis, erit frigida, et si in humidis humida, et si in dissimilibus locis fuerint, ut unus sit in calido signo et alter in frigido, erit quarta illa temperata; eodem etiam modo se habet in humiditate et siccitate. (4) Hoc autem quod iam dixi unum est testimonium. (5) Secundum uero testimonium est cum fuerit dominus anni superioribus commixtus, tunc enim iudicabis per duo testimonia. (6) Et si loca ipsorum et esse diuersa fuerint, scito quis eorum plus fortitudinis habeat. (7) Nam orientalis si fuerit de superioribus, maioris est fortitudinis quam occidentalis; e contrario uero se habet res in planetis inferioribus. (8) Scientia quidem domini anni est scire planetam qui fortitudinem habuerit maiorem super quinque loca dignitatum in principio reuolutionis anni.

19. (1) Dixit etiam Messehallah quod semper commiscendus est dominus anni cum planeta qui fuerit in aliquo angulorum signi ascendentis anni ${ }^{218}$ in principio, similique modo faciendum est in mense quolibet ${ }^{219}$ et in prima quarta et medio mensis necnon et in quarta secunda. (2) Adhuc autem considerandi sunt dies clauium Lune.

${ }^{17}$ prius per sed exp. $V$

218 anni ad principio refert, $c f$. in the bygynnynge of the yere $L$

219 mensis cuiuslibet (sc. in principio mensis cuiuslibet) in every month $L$ 
20. (1) Amplius dixit Albumasar: Magna clauis pluuie est cum coniungitur Saturnus cum Sole in hora coniunctionis uel oppositionis aut fuerit in eius aspectu quocumque in hora clauium Lune, quia tunc significabit pluuiam magnam multis diebus durantem. (2) Clauis uero parua est coniunctio alicuius planete corporalis aut per aspectum cum planeta qui fuerit dominus domus sui detrimenti seu exitii, ut si iungatur Mercurius cum Ioue, nam hoc significat humiditates cum uento forti; et consimiliter Venus cum Marte super humiditate cum coruscatione et tonitrua, Luna etiam cum Saturno significat forte gelu et niuem in hyeme. (3) Dixit quoque rursus Albumasar se expertum esse multis annis quod cum coniunguntur tres planete in signo aquatico ${ }^{220}$ significat humiditates.

21. (1) Iterum dixit Benneka Indus: Si fuerit signum coniunctionis uel oppositionis aliquod signorum aqueorum, hoc significat pluuiam, et eo magis si aspiciat dominus anni locum coniunctionis ${ }^{221}$, et similiter est in oppositione. (2) Quod si dominus anni fuerit in opposito coniunctionis signi, tunc erit significatio fortior. (3) Et si locus coniunctionis seu oppositionis fuerit in aliquo angulorum signi ascendentis, tunc erit res magis fortis. (4) Et erit pluuia quando perueniet [in] Luna motu suo diuerso ad gradum signi ascendentis, et hoc est expertum. (5) Retrogradatio uero planete, cum est sinistra, significat humiditates et eo magis si euenerit in aliquo signorum aqueorum et fuerit Luna in hora coniunctionis uel oppositionis dans fortitudinem domino domus coniunctionis uel oppositionis ${ }^{222}$ aut illi qui dignitatem habuerit in loco dicto. (6) Hoc enim significat pluuiam et erit tempus euentus eius secundum numerum graduum qui fuerint inter Lunam et radium $^{223}$ planete per coniunctionem aut per aspectum, hoc est secundum complementum numeri. (7) Nam si fuerit inter eos tres gradus, erit pluuia post tres dies, ab hora uero retrogradationis planete usque quo sit in oppositione Solis. (8) Si quidem de superioribus sit, significatur humiditas iuxta hoc quod significare habet ab hora oppositionis sue cum Sole usque ad stationem eius secundam. (9) Simile est in inferioribus planetis suo modo, unde hoc est eis commune a principio stationis prime usque ad oppositionem Solis aut usque ad oppositum augis epicicli. Et non est similiter ab illo loco usque ad stationem secundam. (10) Vniuersaliter autem significatur magis pluuia tempore quo separatur Luna a coniunctione uel oppositione Solis et dederit fortitudinem planete retrogrado, quam significetur si fortitudinem dederit directo. (11) Et si planeta fuerit in statione secunda, significat mundiciem aeris siue serenitatem usque ad quartam quando erit prope oppositum loci sui.

220 aquatico: in alio Aquarii $m g$. $V$

221 coniunctionis: or els opposicioun add. $L$

222 oppositionis: there beynge retrograde $a d d$. $L$

223 radium: the <de>grees (gradum ?) L 
Shlomo Sela, Carlos Steel, C. Philipp E. Nothaft, David Juste \& Charles Burnett

22. (1) Dixit quoque Sahal Iudeus: Attendere debes quolibet die ad partem aeris quam $\left\{61^{\mathrm{v}}\right\}$ ita scies. (2) Mensurare quidem debes quolibet die longitudinem que fuerit inter locum Solis et Saturni ${ }^{24}$ et proicere hunc numerum a loco Lune mane in ortu Solis, et aspice si cadat hec pars in aliqua domorum Saturni, nam hoc significat obscuritatem aeris, si Saturnus ipsam aspiciat et fuerit in aliqua mansionum Lune significantium pluuiam. (3) Quod si ceciderit Luna in aliqua domorum Iouis uel Mercurii, hoc significat uentos et eo melius si fuerit dominus partis in aliquo signorum uentos significantium. (4) Et si fuerit in domibus Veneris, significat humididatem et eo melius si fuerit in aliqua mansionum Lune pluuiam significantium. (5) Et si in domibus Martis, significat mundiciem aeris et claritatem nisi fuerit ipsa pars in Scorpione et Mars in signo aqueo, quia tunc non erit aer serenus competenter. (6) Et si in domo Solis, erit aer serenus, et si in domo Lune, tunc significatur humiditas. (7) Et hoc totum uerum est si dominus partis ipsam partem aspiciat.

23. (1) Sermonem quidem generalem ponit Messehallah dicens: Considera in reuolutione anni et aspice coniunctionem uel oppositionem que fuerit in principio eius. (2) Si sit Luna coniuncta infortune et similiter gradus coniunctionis uel oppositionis siue sit hoc per coniunctionem siue per aspectum et sunt in angulis signi ascendentis, significat hoc annum malum per infirmitates et mortalitatem secundum naturam infortune. (3) Nam Mars significat calorem et bella et eo magis si fuerit in signo figure humane. Luna uero significat super quemlibet hominem in communi. (4) Et si Luna fuerit cum Saturno, hoc significat infirmitates graues et diuturnas maxime si fuerit Saturnus in signo terreo. (5) Quod si Luna fuerit in reuolutione anni in loco cadenti et dederit fortitudinem Ioui aut Veneri et hii non sint in domibus cadentibus, hoc significat quod plures hominum exibunt de angustia ad libertatem, et e contrario si Luna fuerit in loco bono et dederit fortitudinem planete cadenti et eo magis si planeta illa fuerit infortuna. (6) Et scito quod locus Martis significat loca bellorum.

24. (1) Dixit Albumasar: Semper attendere debes ad signum profectionis in principio magne coniunctionis in triplicitate et similiter in principio coniunctionis superiorum in uiginti annis. (2) Et ducas uel dirigas locum coniunctionis prime per gradus equales et similiter per gradus ascensionum loci cuiuslibet. (3) Et in anno quo peruenerit ad locum Martis precise uel ad gradum loci sui primi aut ad coniunctionem eius, tunc significantur bella. (4) Et simili modo faciendum est in iudicio nature cuiuslibet planete. (5) Quolibet uero anno in quo Saturnus est in aspectu quarto cum Ioue et fuerint ipsi in angulis coniunctionis prime, significatur commixtio regum et si sit ibi Mars, considera quando renouabuntur bella.

224 et Saturni s.l. add. $V^{2}$ and that of Saturn add. $L$ 
25. (1) At scito etiam inter antiquos esse discordiam de signis igneis. (2) Nam omnes dicunt signa coniunctionum esse super partem Orientis. Ptolomeus uero dicit significationem ipsorum esse super partem Septemtrionis. (3) Omnes autem antiqui et similiter Ptolomeus concordati sunt signa aerea significare super Occidentem. (4) Et omnes antiqui dicunt quod signa ${ }^{225}$ terrea sunt meridionalia et signa aquea septemtrionalia. (5) Ptolomeus uero consentit quod signa terrea sunt meridionalia, sed ipse dicit ignea esse septemtrionalia.

26. (1) Albumasar quoque dicit se expertum esse multis uicibus, cum significat annus bella, quod hoc est quando intrat Mars sub combustione Solis et sunt 6 gradus aut Iupiter si dignitatem habuerit in signo ascendente hora coniunctionis uel oppositionis que precessit reuolutionem. (2) In quolibet autem anno in quo redierit planeta ad locum eius in principio anni coniunctionis magne, tunc est ligatus cum eius radio et secundum eius fortitudinem renouabitur in illo anno res que est secundum naturam illius planete. (3) Quod si fuerit planeta bonus et sit dominus domus sexte uel $8^{\mathrm{e}}$ aut $12^{\mathrm{e}}$ secundum ascendens hore coniunctionis uel oppositionis precedentis reuolutionem anni, minuetur de bonitate eius. (4) Et si sit infortuna, augmentabitur dolor super dolorem. (5) Et si sit fortuna in aliquo angulorum ciuitatis cuiuslibet, tunc erit melius, et si sit infortuna, tunc erit peius. (6) Et signum cuiuslibet ciuitatis si non fuerit tibi cognitum considera ad magna infortunia que illi ciuitati superuenerunt. (7) Et poteris scire constellationem eius in hora edificationis ciuitatis secundum uiam rationis.

[colophon] Explicit liber de iudiciis reuolutionum annorum mundi quem compilauit Iacob filius Ysaac Alkindi. Expletus est libellus iste ascendente Cancro, in quo Luna coniuncta Ioui, die tertia Septembris anno domini $1278^{\circ}$ in Mechlinia, translatus ex Hebrayco in Latinum per Henricum Bate ad preces Iohannis de Milana.'

225 signa correxi: sunt $V$ 
Shlomo Sela, Carlos Steel, C. Philipp E. Nothaft, David Juste \& Charles Burnett

\author{
II.3. English Translation of the Latin Text \\ (Shlomo Sela with the Assistance of all the Other Authors)
}

\title{
< I. ABRAHAM AVENEZRA: ON THE REVOLUTIONS OF THE YEARS OF THE WORLD >
}

\section{$<1$. On the supercelestial bodies $>$}

1. (1) There is no disagreement among the scholars that all the generated things are connected to the supercelestial bodies, whose power universally flows into all the inferior things. (2) For the souls of all living beings are like forms coming from the movers of the orbs and from the light of the fixed and wandering stars. (3) The power is seen to be greater insofar as the planets are larger and closer to the Earth. (4) Therefore Ptolemy says that if the planet is in the inferior part of the eccentric orb or in the perigee, its [the planet's] power is more manifest on Earth than when it is close to its apogee, and therefore the southern part of the Earth is not habitable, because of the strength of the Sun's heat, because it is the largest among the visible stars. (5) The outstanding scholars too agree that the human soul is connected to the orb of the signs, where the fixed stars are. (6) This is the eighth orb from Earth. All its stars are divided into 48 constellations, of which 21 are northern from orb of the signs [the zodiac], 15 are southern, and 12 are in the great orb, which is the girdle of the orb of the signs. (7) They named each of the 12 parts or divisions <of the great orb> according to the name of the constellation that is close to it in this orb. (8) The Moon and the other five planets sometimes are in the middle line of the orb of the signs and sometimes they go out of it a few degrees to the north or the south [lit., to the right or to the left]. (9) The Sun, though, is always in the middle line of the orb of the signs [i.e., the ecliptic].

\section{$<2$. On the nature of the planets $>$}

1. (1) Before a statement about the conjunctions of the planets is made, let us speak about their natures. (2) It is well known that the scholars have shown by reasons that the nature of the stars is not fiery because the heavens, and anything in them, are not composite, but simple [i.e., consist of one element]; hence it always remains as it is and does not increase or decrease, and these sublime creatures do not change in any way. (3) Hence, the Psalmist said about them: "He hath also established them for ever and ever ». [Ps. 148:6]

2. (1) But here a difficult question has been asked, namely, why the scholars of the judgments of the stars said that the Moon is cold, and Mars, which is wholly fiery, is hot. (2) Some even say: we have tested these things and found that this star [Mars] generates heat and that one [the Moon] <generates> cold. (3) But Ptolemy says that the Moon is cold and humid because it is close to the Earth, from which comes a great humidity to it [the Moon]. (4) He also said that the Sun is of a hot 
nature, and since <the nature > of heat is to ascend, therefore Mars is hot; Saturn, indeed, is cold since it is far away from the other planets; Jupiter is temperate since it is intermediate between heat and cold.

3. (1) Jacob al-Kindi said that four signs are the beginning of the revolutions of the tropics [i.e., mobile signs], and since heat is active, therefore it is said that Aries is hot. (2) Heat and cold are active, and when the Sun is straight in Aries, it is rising with respect to our inhabited part <of the Earth> and then plants are germinated and diseases are caused. (3) They said that Cancer is cold <and that $>$ cold is similarly active.

4. (1) Therefore other said that the judgments of the stars are derived from proportions. (2) For the proportion of the orb of Jupiter to the orb of the Sun, and to the orb of the Moon, and to the Earth, is a friendly proportion. (3) The opposite applies to the proportion of Saturn and Mars. (4) <The number of > the Moon is like 12 , of Venus and Mercury is like 14; of the Sun is 18 and of Mars is 20, of Jupiter is 24 and of Saturn is 32.

5. (1) The truth is that any light is generative of heat, and since the body of the Moon is smaller than the body of the Earth, and <the body> of the Sun is 166 times larger than that of the Earth, therefore the Sun generates a great heat. (2) Since the nature of the small heat, which is loose, is mitigating and allowing fluidity, hence this light, by its heat, which is small, increases humidity but not so the Sun. (3) Venus is close to the Moon's nature because its light is great, and it is also close to the Earth, therefore both signify rains. (4) Mercury, since it is small, is similarly changed, for its light is small. (5) Jupiter, since it is the largest of all the planets after the Sun, and is far away from the Earth, it is therefore generative of moderate heat and humidity, which is of the nature of life. (6) Since the Sun is parching, because of its intense heat, and Mars is large and its orb is close <to the Sun>, it generates a great heat. (7) They said that this is its nature and the reason for its action and effect. (8) Saturn, since it is far away from the Earth, its light is therefore not generative of heat according to the mixture that is appropriate to man, although the light in itself is generative of heat. (9) An example of this is that the scholars of medicine say that bovine flesh is cold; they are right, when <bovine flesh is > compared to the human body, and yet it is hot inasmuch as it is flesh.

6. (1) Because they found the nature of the signs through a comparison with things on Earth, they said that Aries is hot and moderately dry, and likewise for the fifth and ninth <sign> from it, Taurus is cold and dry, Gemini, according to its human shape, is hot and humid, Cancer is cold and humid, like the nature of water. (2) There is no need to prolong this discussion, because the truth of the ratios is in the aspects, and there is no disagreement on this. For Aries, Leo and Sagittarius are hot and dry; Taurus, Virgo and Capricorn <are> cold and dry; Gemini, Aquarius and 
Shlomo Sela, Carlos Steel, C. Philipp E. Nothaft, David Juste \& Charles Burnett

Libra are hot and humid; Cancer, Scorpio and Pisces are cold and humid. (3) Moreover, they all agreed that the Moon is close to the Earth, and that it signifies the nature of the native according to the condition of its location and according to how others aspect it [the Moon]. (4) Mercury signifies the discernment of reason and the human soul; Venus, because it is located high, <signifies> the desire to continue the species; the Sun is like the heart in the human body, for with the heart the soul increases the heat; therefore the heart is related to the Sun; the upper planets signify universal matters; Saturn <signifies> an ancient people and an ancient kingdom; Jupiter <signifies> a new people and a new kingdom; Mars is a significator of wars and victories; it seems that it does not happen that kingdoms change unless by wars.

\section{$<3$. On conjunctions >}

1. (1) When we examined all the conjunctions of all planets, we found that they are 120 , because there are 21 <conjunctions> of two <planets>, and similarly of 5 $<$ planets>, and <there are> $35<$ conjunctions> of three <planets>, and similarly of 4 $<$ planets>, <there are> $7<$ conjunctions > of $6<$ planets $>$, and all of them derive from seven, they multiply odd numbers by duplication and there is no number except 7 and septenial. There is one conjunction of the seven <planets>.

2. (1) The root of the significations of general matters is according to the two upper planets, and the beginning of their conjunction is in Aries. (2) After 20 years they conjoin Sagittarius, and after other 20 years in Leo, <...> and they proceed in the same way for 12 or 13 times. (3) This occurs in 240 or 260 years. (4) After the fiery signs they shift to earthy signs <and conjoin> in the same way as they did in the fiery signs. (5) Afterwards they shift to the airy signs, and subsequently <they shift> to the watery signs. (6) The conjunction in the triplicity is called the great conjunction. (7) The conjunction of 20 years is the small conjunction.

3. (1) It is not possible for a man to find the minute of the conjunction of the planets because of the slowness of their motion. (2) The locations of the planets are found by observational instruments, by which seconds cannot be marked on [i.e., marked on the instruments]. (3) Consequently, the scholars of the judgments of astrology relied on the revolution of the world-year and on the ascendant in the place of the equal line or the middle of the world, moreover, on the ascendant of the place under consideration according to its longitude and latitude, as it is written in the Book of Tables. (4) Moreover, Ptolemy says that the judgment of a year depends on the moment of the conjunction of the luminaries or their opposition that takes place before the revolution of that year, and this should be associated in any year to the conjunction or opposition of the luminaries immediately preceding the entrance of the Sun into the mobile signs. (5) It is also necessary to know with earnest attention the degree of the ascendant in any place at the moment of the 
conjunction of the luminaries or their opposition in the month in which the two upper < planets> will conjoin, and this is the truth.

4. (1) Know that the sign of the Jews is Aquarius, Leo <is the sign> of the Christians, Scorpio of the Muslims. (2) Those who rely on experience also said that the constellation of the Muslims is Venus with Scorpio, because the conjunction of the sect of the Muslims took place in the term of Venus. (3) Many of the scholars also observe the conjunction of Saturn and Mars that takes place every 30 years in Cancer.

\section{$<4$. On the judgments of the world-years >}

1. (1) We shall now discuss the judgments of the world-years. (2) First we enjoin you not to rely on the cycles of 2000 years according to the degrees of the zodiac, and not on the <cycles of $>2000<$ years $>$ according to the reckoning of the signs, and not on the <cycles of $>2000<$ years $>$ according to the reckoning of the planets. (3) For all this is nothing else than a destruction of thought and it is not beneficial to anyone to read books on cycles of 10, 100, and 2000 years. (4) You must know that the judgments of the world are a matter related to rains, and to the year of famine, of diseases, of wars and also of the changing of kingdoms.

\section{$<5$. On the lunar mansions >}

1 (1) It is proper to remember the significations of the lunar mansions on rains, also the significations of the mansions on dryness. (2) I will present their shapes and names in Arabic.

2. (1) The first mansion is al-nath, that is, the ram's horns, consists of three thirdmagnitude stars, arranged in this way $\cdot:$ (2) The second mansion is al-butayn, that is, the ram's small belly, consists of three small $4^{\text {th }}$-magnitude stars :. (3) The third $<$ mansion is $>$ al-thurayy $\bar{a}$, which are the Pleiades, and it is the ram's tail, consists of six $4^{\text {th }}$-magnitude stars : $\because$ (4) The fourth $<$ mansion is $>$ al-dabarān, a bright red star of the first magnitude $\cdots:$ : and it is the eye of the bull. (5) The fifth <mansion is>al$h_{a q}$ ' , the head of the twins, consists of three small second-magnitude stars between two bright <stars $>\therefore$ of the second magnitude. (6) The sixth <mansion is> al-han'a, close to the twins, consists of three third-magnitude stars with the similitude of an arrow $\because$ : (7) The seventh <mansion is $>$ al-dhir $\bar{a}^{c}$, that is, the arm, consists of two bright stars close to the head of the twins : (8) The eighth $<$ mansion is $>$ al-nathra, that is, the lion's nose, consists of two small stars in the similitude of a cloud, of the fourth magnitude $\therefore$ (9) The ninth <mansion is $>$ al-tarf, that is, the eye, and it is the eye of the lion, consists of 3 small stars $:$, the third is below and hidden, of the fifth magnitude. (10) The tenth <mansion is>al-jabha, that is, the forehead of the lion, consists of 4 stars of the third and fourth magnitude :: (11) The $11^{\text {th }}<$ mansion is $>a l-z u b r a$, and others name it al-kharātān, and it is the side of 
Shlomo Sela, Carlos Steel, C. Philipp E. Nothaft, David Juste \& Charles Burnett

the lion, consists of two stars, a small and a large one, of the second and fifth magnitudes : (12) The $12^{\text {th }}<$ mansion is $>$ al-șarfa, that is the tail of the lion, consists of one large star of the first magnitude. (13) The $13^{\text {th }}<$ mansion is $>$ al- $a w w \vec{a}$, consists of four sixth-magnitude stars, and above there is a small bright star :... (14) The $14^{\text {th }}<$ mansion is $>$ alchemaah, which is al-simāk al-a'zal, that is the unarmed, and the reason is that it does not have spears, consists of one bright star of the first magnitude . (15) The $15^{\text {th }}<$ mansion is $>$ al-ghafr, <consists of $>$ three small fourthmagnitude stars $:$, and it is the tongue of the scale. (16) The $16^{\text {th }}<$ mansion is $>a l$ zubānā, which are the pans of the scale, consists of two second-magnitude stars .. (17) The $17^{\text {th }}<$ mansion is $>$ al-iklill, that is, the crown of the scorpion's head, consists of three third-magnitude stars ... (18) The $18^{\text {th }}<$ mansion is> al-qalb, that is, the heart of the scorpion <consists of $>$ a great star of the second magnitude between two small shining stars ... (19) The $19^{\text {th }}<$ mansion is $>$ al-šawla, that is, the sting of the scorpion, it consists of two stars of the fourth magnitude grouped with other small stars. (20) The $20^{\text {th }}<$ mansion is $>a l-n a^{\prime} \bar{a}^{\prime} i m$, it consists of 8 stars, four grouped on one side and four grouped on the other side; above there is a bright star; they are of the third and fourth magnitudes $\cdot \cdot(21)$ The 21 th $<$ mansion is $>$ al-balda, it is in the likeness of the letter that the Hebrews call het but reversed, it consists of 6 stars in the form of a arch $\cdot . . \cdot(22)$ The $22^{\text {nd }}<$ mansion is $>$ sa' $d$ al-dhäbih, and this is difficult to write in Hebrew, and it means the luck of the butcher or slaughterer, consists of three stars, a small one between the other two : (23) The $23^{\text {rd }}<$ mansion is $>$ sa'd al-bula', consists of two stars, one as if swallowed up by the other, and the two are small : (24) The $24^{\text {th }}<$ mansion is $>$ sa' $d$ al-su' $\bar{u} d$, consists of two stars, that is one large <and one small> and close to them one small .: (25) The $25^{\text {th }}<$ mansion is $>$ sa'd al-akhbiya, consists of four stars, two of them standing like a wave on the $<$ other> two, which do not emit as much light as the other two :: (26) The $26^{\text {th }}$ $<$ mansion is> al-fargh al-awwal, that is the urn of the water-carrier, consists of two stars of the fourth magnitude : (27) The $27^{\text {th }}<$ mansion is $>$ al-fargh al-thanni, that is the posterior urn, consists of two stars <located> south of the urn of the watercarrier : (28) The $28^{\text {th }}<$ mansion is b batn al-hüt, that is the belly of the fish, consists of seven stars arranged in the similitude of the body of a fish, and they are close to the orb of the signs [i.e. the ecliptic].

3. (1) I shall therefore compile a table to know the mansions and how many degrees, minutes and seconds each of them contains. (2) This table has been corrected, and its division is according to the eighth orb. 


\section{Corrected table of the lunar mansions according to the agreement of the philosophers}

1. Aries, al-națh that is the horns,

2. Aries, al-butayn,

3. Taurus, al-thurayya, that is, the Pleiades,

4 Taurus, al-dabarān, that is, the Hyades,

5 Gemini, al-haq'a, that is, falling,

6 Gemini, al-han'a,

7 Gemini, al-dhirā ,

8 Cancer, al-nathra, that is, the fugitive,

9 Cancer, al-țarf, that is, unimpeded dry,

10 Leo, al-jabha, that is, forehead,

11 Leo, al-zubra that is, flourishing,

12 Virgo, al-șarfa, that is, hairs,

13 Virgo, al-'awwä, that is, weasel,

14 Virgo, al-simāk, that is, spike,

15 Libra, al-ghafr, that is, bitter,

16 Libra, al-zubānā, that is, conjoined humid,

17 Scorpio al-iklil, that is, crown,

18 Scorpio, al-qalb, that is, unimpeded dry,

19 Sagitarius, al-šawla, that is, destroyed,

20 Sagitarius, al-na' $\tilde{a}^{\prime} i m$, that is, delight,

21 Sagitarius, al-balda, that is, boundary,

22 Capricorn, sa'd al-dhäbih, that is, serpent,

23 Capricorn, sa'd al-bula', that is, swallower,

24 Aquarius, sa'd al-su' $\bar{u} d$, that is, bright serpent,

25 Aquarius, sa'd al-akhbiya, that is, dry serpent,
12.51.26, temperate

25.42.51, dry

8.34.17, temperate

4.21.26.43, humid

4.17.9, temperate

17.8.34, dry

7.30.0.0, temperate (†humid)

12.51.26, temperata

25.42.51, dry

10.8.34.17, temperate (†humid)

21.25.43, temperate

12.4.17.9, humid

17.8.34, dry

30.0.0, temperate

15.12.51.36, temperate (†humid)

16.25.42.51, humid

8.34.17, humid

21.25.43, dry

19.4.17.9, temperate, (†humid)

17.8.34, temperate (thumid according to $<$ John $>$ of Seville and the seasons of the Indians)

30.0.0, temperate

20.12.51.26, humid

25.42.51, temperate

8.34.17, temperate

21.25.43, dry 
Shlomo Sela, Carlos Steel, C. Philipp E. Nothaft, David Juste \& Charles Burnett

26 Pisces, al-fargh al-awwal, that is, dry blow,

27 Pisces, al-fargh al-thāni, that is, stock of a bean,

28 Pisces, bațn al-hūt, that is, fishes,
4.17.9, dry

17.8.34, humid

30.0.0, temperate

4. Note that there are six mansions that are principally humid, according to the evidence provided by Al-Kindī, and Ibn Ezra enumerates only those as humid, and they have been indicated here.

\section{$<6$. On the solar year >}

1. (1) But now we wish to speak about the disagreement between the tables of the Ancients and those who came after. (2) Regarding this, the Ancients agree that the solar year contains truly 365 days and a quarter of a day and also 1/120 of a day, from which it follows that the <rotational $>$ excess above 365 whole days is approximately $93^{\circ}$. (3) Yet the scholars of Persia say that in this excess 15 minutes of a degree are added to these $93^{\circ}$. (4) Ptolemy says that from this additional quarter of a day there is a deficit of $1 / 300$ of a day, which amounts to one degree and 12 minutes. (5) After Ptolemy emerged many scholars at different times who examined and proved that the solar year is $1 / 120$ of a day shorter than this additional quarter. (6) And it is in fact astonishing how such a great error can emerge. For in 60 years a difference of one day will occur between those who posit the greatest value of the year and the others who make it smallest. (7) And this is something anyone can test through the shadow and also through observational instruments.

2. (1) Other scholars said that there are two small circles at the heads of Aries and Libra, and according to this view they said that there is sometimes an ascent and sometimes a descent. (2) And some within this group disagree with the others. (3) Some say that this motion goes as far as $8^{\circ}$. (4) Others, making finer distinctions, say it goes up to $102 / 3^{\circ}$. (5) The Indian scholars say that this is the motion of the fixed stars, but this is not so. (6) For it appears clearly that Ptolemy found in his time through observational instruments that the Sun enters the head of Aries, when day equals night in all the climates, eight days after this happened according to the reckoning of the Indians. (7) Therefore he said in the Book of Figures that it is necessary to add $8^{\circ}$ to know the figure of the revolution of the orb of the signs. (8) But nowadays it is the other way round, because the Sun enters the head of Aries and days equals night nine days before this happens according to the reckoning of the Indians. (9) Hence there were $8^{\circ}$ in the year of the conjunction of the two upper < planets> in Virgo.

3. (1) I shall now reveal part of this secret. (2) Know that there are two groups among them. (3) Some of them acknowledge the beginning of the year at the equinoctial point, whether the motion of ascent or descent be true or not. (4) 
Others, by contrast, take the Sun's return to the position of a fixed star, whether the orb of fixed stars moves by one degree in 100 years, or in 66 years and 8 months, or in 70 years, or the starry orb has no other motion except that of ascent and descent. (5) The number or quantity of the Sun's motion from one point to the same point is the same except that there is a motion to the orb of the Sun, whose center is removed from the center of the Earth, because the motion of its apogee is equal to the motion of the fixed stars. (6) I shall give an examples thereof. (7) Ptolemy says that the motion of the fixed stars in one year is $1 / 100$ of a degree, which amounts to 36 seconds and to which correspond $3^{\circ} 36^{\prime}$ per year of the rotational motion of the heavens. (8) He also said that from the quarter of a day in the solar year, 1/300 of a day, which amounts to $1^{\circ} 12^{\prime}$ of the rotation of the orb, is lacking. (9) And when this number is subtracted from $3^{\circ} 36^{\prime}$, there will be a remainder of $2^{\circ} 24^{\prime}$. (10) And according to this the solar year from a fixed star to its return to the same <star> will have an excess of $1 / 150$ of a day. (11) The Arab scholars said that the motion of the fixed stars is one degree in 66 years, to which correspond $5^{\circ} 27^{\prime}$ according to the aforementioned method. (12) But they said that in the solar year there is a decrease of $1 / 115$ of a day, to which correspond $3^{\circ} 13^{\prime}$. When this is subtracted from that which corresponds to the motion of the fixed stars, there will be a remainder of $2^{\circ} 14^{\prime}$. (13) Other masters of the observations, most profound researchers, found that the motion of the fixed stars is one degree in 70 years, to which correspond $5^{\circ} 9^{\prime}$ per year, and according to their reckoning the decrease of the solar year from a quarter-<day> is $2^{\circ} 45^{\prime}$. When this is subtracted from the aforementioned number, there is a remainder of $2^{\circ} 24^{\prime}$, as Ptolemy posits.

4. (1) All the scholars of the stars call the point where the length of the day equals the night the head of the sign of Aries, because the constellation of Aries is close to it according to what is seen. (2) The remaining signs were divided according to their constellation following that example <of Aries>. (3) The Indian scholars, however, divided the orb of the signs according to what appeared to their eyes, according to what they have tested and proved in the judgments one generation after the other, and this division is according to the constellations seen in the orb of the signs, that is, the eighth orb.

\section{$<7$. On the great conjunction of the year 1067>}

1. (1) When we examined the great conjunction that took place in the earthy signs, we ourselves found Saturnus in Sagittarius $28^{\circ}$, in the year of the Arabs 438, and we found towards the end of that year, that is the year of Christ 1047, that Jupiter just entered he first degrees of Capricorn according to the division of the signs, and both were in the constellation of Sagittarius. (2) Therefore, the beginning of the year of the conjunction was in the year of the Arabs 459 on the $25^{\text {th }}$ day of the 
Shlomo Sela, Carlos Steel, C. Philipp E. Nothaft, David Juste \& Charles Burnett

fourth month, and, according to the Christians, on the $14^{\text {th }}$ day of March in the year of Christ 1067. (3) And since we wish to know the degree of the ascendant in the place of the equal line, which is called Aryn, (4) and we already know that the longitude of Winchester from the Occident is $19^{\circ}$ and that its longitude from the middle of the world is $71^{\circ}$, which amount to 4 hours and 44 minutes, and the uniform motion of the Sun in these hours and minutes is 11 minutes and 40 seconds, (5) we find the motion of the Sun in the collected years 1049 and in the expanded years 17 completed, and the mean motion of the Sun was 11 signs, 14 degrees, 46 minutes 40 seconds, from which are reduced 11 minutes and 40 seconds, and there will be a remainder of 11 signs, 14 degrees, 34 minutes, 0 second. (6) We also made provisions to know the place of the Sun's apogee, for which it is necessary to subtract 33 years from 1100 years, which are the root of the apogees. (7) And the motion of the apogee in these 33 years is 28 minutes. We subtracted these from the place in the written table, which is 2 signs, 26 degrees, and 14 minutes, and there was a remainder of 2 signs, 25 degrees, and 46 minutes. (8) And the equation of the Sun was of 1 degree, 58 minutes, and 48 seconds. (9) We subtracted this from the beginning of Aries, and the remainder was 11 signs, 28 degrees, 1 minute, 12 seconds. (10) From this we also subtracted the aforementioned number that comes from the collected and expanded years, and the remainder was 13 degrees, 27 minutes, 12 seconds. (11) From this we also subtracted what we found for the motion of the Sun in 13 days, and the remainder was $0^{\circ} 34^{\prime} 24^{\prime \prime}$. (12) To this number correspond according to the motion of the Sun 19 hours, 34 minutes, and this revolution of the year at the place of the equal line and the ascendant degree is $25^{\circ} 24^{\prime}$ of the sign of Aries, and the entrance of the Sun into the head of Aries in this place, which is Winchester, was at 14 hours and 50 minutes after noon and these fractions were $5 / 6$ of an hour, which are 10 minutes, and this took place in the $9^{\text {th }}$ hour of the night according to the $312^{\circ}$ degrees of the ascensions of the country, and the ascendant sign was $9^{\circ} 43^{\prime}$ of the sign of Capricorn. (13) These are the positions of the planets: Sun, 0.0.0; Moon, 10.22.28; Head of the Dragon, 5.11.30.14; Saturn, 5.14.55, retrograde; Jupiter, 5.2.1, also retrograde; Mars, 0.14.26; Venus, 0.7.15; Mercury, 11.9.7. (14) And this is the position of Saturn and Jupiter at the moment of their conjunction according to the tables I myself composed: Saturn, 5.12.23.17; its equated position, 5.18.51; Jupiter, 5.18.22.46, its equated position, 5.18.51; Sun, 5.18.54.41; its equated position, 5.16.57. (15) I also equated the positions of the planets according to the method of Al Battānī, al-Ma'mūn, al-Ṣūfī, and al Mazkar; there is a disagreement among them regarding the position of the apogee of the Sun, and this is because it is impossible for the examiner to know the position of the apogee except by means of instruments. (16) But in this there is a great difficulty because no instrument can be made in which seconds can be discerned. And if the years are multiplied, the seconds can grow to a perceptible quantity. (17) I also found their conjunction on 
the day on which the Sun was conjoined with them within two days, namely after the conjunction of Saturn and Jupiter, in one degree and one minute, and this took place after five completed days in the month of September of the year 1067 according to the years of the Christians. (18) And according to the Arabs this is after 23 days of the month of Shawwāl, which is the tenth month in their reckoning of the year 459 from the beginning of their reign. (19) These are the positions of the other planets on the day of this conjunction: Mars, 4.7.13; Venus, 4.9.5; Mercury, 6.12.25; Moon, 3.10.12; the Head of the Dragon was near its position on the day of opposition. (20) It was certainly necessary for me to know the Sun-Moon opposition that happened before this conjunction on 26 August: mean motion of the Sun, 5.11.1.26; mean motion of the Moon, 11.7.50.24; portion of the Moon at noon of this day, 7.2.39.52. (21) The opposition was in Pisces $8^{\circ} 59^{\prime} 1^{\prime \prime}$; the position of the Head of the Dragon at the moment of the opposition, 5.6.50.48. The latitude of the Moon was only 11 minutes and for this reason what it signifies is complete. (22) The ascendant in Winchester is $18^{\circ} 17^{\prime}$ Libra and on the equal line it is $10^{\circ} 5^{\prime}$ Capricorn.

Here follow the three horoscopes printed on p. 254-256 above.

\section{< II. AL-KINDĪ (?): BOOK OF THE JUDGEMENTS OF THE REVOLUTIONS OF THE YEARS OF THE WORLD, FIRST TREATISE >}

1. (1) The translator said: I shall now translate a tractate from Arabic into Hebrew on the judgements of the world-years compiled by Ya'qub, the son of Isaac al-Kindī. This is the beginning of his treatise.

2. (1) Since all astrologers [lit. judges of the stars] agree that the judgments of universal or general matters depend on the conjunction of the two upper <planets> [i.e., Saturn and Jupiter], I shall start from the beginning of their conjunction in the signs of the triplicities. (2) For from the fiery signs they shift to the earthy signs. (3) You need to look at the chart of the configuration of the orb of the signs [i.e., the horoscope]. (4) Know the sign of the conjunctions to which belongs one of the parts or regions of the Earth. (5) You also need to find out, to the best of your ability, the degree of the ascendant at the moment when the Sun enters the sign or the constellation of Aries. This time is to be obtained from the tables compiled by the method of observation: <adding> $8^{\circ} 45^{\prime} 30^{\prime \prime}$. (6) The Sun enters the constellation of Aries between the $22^{\text {nd }}$ and $23^{\text {rd }}$ day of March. (7) Calculate $<$ the positions of $>$ the planets according to this day and hour, and subtract the aforementioned number from the position of the Moon and from the position of the remaining five planets. (8) Also calculate, as precisely as you can, the conjunction or opposition of the luminaries, the one of the two that is nearest to 
Shlomo Sela, Carlos Steel, C. Philipp E. Nothaft, David Juste \& Charles Burnett

$<$ the moment> before the Sun enters the beginning of Aries in the year in which the two upper <planets> conjoin. (9) Examine the sign of the nation under consideration, and also the sign of the country or region under consideration, and their position with respect to the sign of the conjunction and to the ascendant sign at the time of conjunction or opposition of the Sun and Moon. (10) Likewise, observe the disposition of the planets and the lord of the sign of the nation and of the city, whichever it may be. (11) It is also very necessary to take notice of the ascendant sign at the beginning of the year, to find out which planet is in a cardine, in a <place> succedent to a cardine, or in <place $>$ falling from a cardine, and how the planets are configured with respect to the Sun.

3. (1) Always relate the Sun to kings, great princes or magnates; Saturn to ancient people and cultivators; Jupiter to judges and priests; Mars to soldiers, warriors and surgeons; Venus to women, physicians and eunuchs; Mercury to scholars, scribes and traders; the Moon to common people in general.

4. (1) Enoch, who is Hermes, says that Aries and Jupiter signify portions of Alaerac, that is, Iraq, which is in the land of the Persians, and there is Babylonia and Baghdad. (2) Saturn with Libra <signify> Rome and the lands of the Christians or the uncircumcised. (3) The Sun with Aquarius <signify> the land of the Jews, that is, Judea, up to Egypt. (4) Capricorn with Mercury <signify> the land of al-Hind?, that is, of the Indians. (5) Venus with Scorpio <signify> the lands of the Cumeans, that is, the Arabs. (6) Leo with Mars <signify> those who live in the seventh climate. (7) The Moon with Virgo <signify> portions of China.

5. (1) The scholars of Babylon spoke of the regions of the Earth. (2) They said that Aries signifies Persia, Azerbaijan, Galatia, Philistin, that is Palestine, Babylon, Valgaa, Mosul, that is, Assyria. (3) Taurus <signifies> Isfahan, Mea (Māhān?), Caberas, Asia Minor, and the mountains of Deberaz (Kurds?), the mountains are very large. (4) Gemini <signifies> Jīlān, Margaan (Mūqān?), Tabaristan, Greater Armenia, Azerbaijan, Jurjān, Camaniaa (Kirman?), Alarquia, Abarabalini, the angle of the West and Egypt, and the land of Barqa. (5) Cancer <signifies> Africa, Philestin, that is, Palestine, Parnessie, the land of the Christians, that is, the uncircumcised, Romania, Lesser Armenia, the eastern part of Khurāsān, Marca, Baldar (Balkh?), and Iraq. (6) Leo <signifies> the land of Alterath, that is, the land of the Turks, Bascetar, Italy, Rome, Great Britain, the land of Hemes, Damascus, the reign of Assur, Atup (Kūfa?), Alboster (Arbashahr/Basra?), and Gog et Magog. (7) Virgo <signifies $>$ the land of Constantinople, Acristas, the sea of the Palestinians, Canaan, and Segastaa. (8) Libra <signifies> the land of Cahara (sahāra?), Sigistān, Tukhāristān, Miscemat, Timas, which is a major city in the land of the Indians, the river of Egypt, and the land of Ethiopia. (9) Scorpio <signifies> Alhagan (Hejaz), Emal (Yemen?), Tangier, Harbar Samara, Soria, Soaz, Canat, Caana, Thersoz Aendaria, Placania, Cuin, Allaaz, Aabdaeri, and the Arabs. (10) Sagittarius 
<signifies> Alumin (Yemen?), Sardinia, Hispania, Sicily, and Arabia of the Ancients. (11) Capricorn <signifies> India, Alchoz (al-khabsha?), Makrān, Ahwāz, Aaraquia, Metarmonia, that is, Macedonia, Halaoham, the Ethiopians, the river Makrān (Indus), that is, of Egypt, Shatț al-Bahr (the coast), Omān, and Alerchenaz up to the land of China. (12) Aquarius <signifies> Assyria, Nota (Kūfa?), Ballac, Sceaz, Bascea, Lonia, Aoquia, Asia, and the land of Egypt with its shares in the land of Persia. (13) Pisces <signifies> Lactabia, which is Anglia according to some people, Ballac, Asania, Heurenia, Nicaz, Lascemoperaz, Paresalia, the land of Altin, Gangaen, the Red Sea, and he selected Yemen, that is, the Sea of Scena, and Malamonia. (14) It also signifies the land of Ethiopia, Alexandria, and part of the lands of the Christians, that is, the uncircumcised.

6. (1) Baldac, that is, Baghdad, whose sign is Cancer $24^{\circ}$, is in the fourth climate. (2) The same applies to Jerusalem, but its sign is Leo $19^{\circ}$. (3) The sign of Egypt is Capricorn; of Cartagena is Gemini, of Toledo is Virgo; of Granada is Cancer; of Seville is Pisces; of Valencia is Scorpio; of Saragossa is Aries; of Pisa is Aquarius; of Lucca is Cancer. (4) Virgo with the Moon <governs> Persia and the land of Syria; Leo with Mars, the seventh climate; Scorpio with Venus, the land of Mecca up to Egypt. (5) These things were discovered through the experience of great events.

\section{< III. AL-KINDĪ (?): BOOK OF THE JUDGEMENTS OF THE REVOLUTIONS OF THE YEARS OF THE WORLD, SECOND TREATISE >}

1. (1) The translator said: I shall now translate from Arabic a famous treatise compiled by Yaqub, the son of Isaac al-Kindī, who was very learned in all the sciences, methods and matters, and possessed many books. (2) This man said that he received true statements on matters related to the conjunctions of Saturn and Jupiter from the statements of the Ancients. (3) He himself spoke about wars, rains, years of dearth and generally about the accidents of the world. (4) This is the beginning of his treatise.

2. (1) One must always consider the beginning of the year of the conjunction in a triplicity, because it does not matter whether the triplicity is fiery, earthy, airy or watery. (2) Consider carefully so as to know the degree of the ascendant under the equal line, where the middle of the world is, at the moment of the conjunction or opposition of the luminaries that takes place before the Sun enters the beginning of Aries, because this is the beginning of the revolution of the world-year or orb. (3) Know also the sign of the revolution, and likewise the sign of the ascendant of the place under consideration at the moment of the conjunction or opposition and at the moment of the revolution of the year, and the sign of the ascendant in the place or city under consideration, as well as the position of the Moon with precision, because it is necessary to know the degree of the revolution of the year 
Shlomo Sela, Carlos Steel, C. Philipp E. Nothaft, David Juste \& Charles Burnett

to know which planets are in the cardines, or in the <places> succedent to the cardines, or in the <places $>$ falling from the cardines, and their configuration with respect to the Sun, and what their dignities in their positions are, and whether they are in signs similar or contrary to their nature, also what the sign of the world is, and which <planet> rules them and aspects any degree of the ascendant from the position of the Moon, and which <planet> aspects a fortunate and unfortunate <position> according to the nature of the planets when the direction [tasyir reaches it, either according to the motion of the planets to the position of a fortunate or unfortunate planet in agreement with its nature, or <according to> their rays in equal degrees.

3. (1) Māshāallāh says: the degree of the ascendant must always be led or directed to know the genus of that region, and likewise the Moon, <and> the tenth $<$ horoscopic> place to know the state of the kings. (2) He also says that the Sun signifies kings. (3) For if the Sun is unfortunate and <also> Jupiter, a misfortune will befall the king of al-'Irāq. (4) If the Sun is unfortunate with Saturn, a misfortune will befall the king of India. (5) If the Sun <is unfortunate> with Mars, a misfortune will befall the king of al-'Irāq, that is, of the Turks, and the lord or prince of the seventh climate. (6) If the Sun <is unfortunates with Venus, a misfortune will befall the king of the Arabs. (7) If the Sun <is unfortunate> with Mercury, a misfortune will befall the king of the Romans, that is, of Christians. (8) If the Sun <is unfortunate> with the Moon, a general misfortune will befall the kings and all their subjects.

4. (1) Abū Ma shar said: You must examine in the year under consideration the sign of the profection from the sign and degree of the conjunction in equal degrees. (2) Observe, if some <planet> aspects the sign of the profection [also tasyir] at the beginning of the conjunction, or at the moment of the revolution of the worldyear, assign to every degree 12 days, and half a day, and the sixth of one day. (3) He gave an example: the sign of the profection $<$ moves $>$ from Libra $8^{\circ}$ to Scorpio $8^{\circ}$; Jupiter is at Libra $12^{\circ}$; Saturn is at Scorpio $2^{\circ} 30^{\prime}$. (4) You need to know that any region or city whose sign is Libra will be strengthened in that year if Venus is similarly fortunate at the beginning of the conjunction and in the revolution of the year; the contrary applies if it [Venus] is unfortunate. If in the conjunction this is fortunate and in the revolution unfortunate, there will be a small defect of good fortune; but if in the conjunction this is unfortunate and in the revolution fortunate, there will be a small defect of bad fortune. (5) Since the longitude is $4^{\circ}$, good fortune will come to any place whose sign is Libra after 49 days. (6) The profection will reach the position of Saturn after ten months, which will signify diseases, diarrhea or constipation, and this will also signify wars, because Saturn is in the house of Mars and in its [Mars's] term. 
5. (1) Kanakah, the Indian, said: attention must always be paid to the power of the twelfths of the degree of the ascendant, because the power of that <twelfth $>$ which you have entered will be in the place in which the number of the signs will be completed, namely, the sign in which the number will be completed. (2) $<$ Example:> The degree of the revolution of the year is Cancer $18^{\circ} 30^{\prime}$, then the degree of the twelfth will reach Aquarius $12^{\circ}$. (3) If the configuration of the stars is fortunate, good fortune will come to any place whose sign is Aquarius, and conversely if it is unfortunate. (4) You must also pay attention to the sign of the profection. Likewise, pay attention if something fortunate or unfortunate is removed according to the configuration of the stars with respect to the position of any place whose sign is the sign of the profection. (5) Know that Saturn signifies an ancient or bygone kingdom, which was in existence before the beginning of the conjunction of the triplicity. (6) Jupiter signifies a new or existing kingdom.

6. (1) Examine also in their conjunction which of them prevails over the other. (2) For the one that is closer to the apogee of its epicycle prevails over the other, and you will be able to know this by the calculated argument of Saturn and Jupiter. (3) You also need to observe which of them is closer to the apogee of the eccentric circle, and you will be able to know this by the calculated centers. The one that is closer to the apogee will prevail. (4) You also need to take into account their latitudes. For the one with a northern latitude will be victorious over the one that is in the line of the signs. The one that is in the line of the signs will be victorious over the other the one that is southern. If both are northern, the one with most northern latitude is victorious. If both are southern, the one with the smaller latitude is victorious. If both <are> in the line of the signs, Saturn will be victorious because it is the higher.

7. (1) You also need to take into consideration their powers according to their dignities in the position of the conjunction, that is, the dignity of house, exaltation, triplicity, term and decan; <you also need to take into consideration> which of them in the revolution of the year rules the ascendant sign in the place under consideration, the place of the Sun, the place of the Moon, and the place of the conjunction or opposition of the luminaries that preceded the entrance of the Sun into Aries, and also the place of the lot of Fortune.

8. (1) Māshāallāh also says: you need to scrutinize in any revolution the planet that is oriental of the Sun, because it is partner in the lordship of the year. (2) If the degree <of the oriental planet> is in one of the cardines, forming an aspect to any place, then the power is greater. (3) If it is occidental of the Moon, then its power is very great.

9. (1) You also always need to examine which of them rules the five places of dignities at the time of the conjunction or opposition of the luminaries preceding 
Shlomo Sela, Carlos Steel, C. Philipp E. Nothaft, David Juste \& Charles Burnett

the entrance of the Sun in Aries. (2) If it [i.e., which of them rules] gives its power to an upper planet, you must judge according to the nature of the planet receiving the power. (3) You must combine the nature of the dignities with the nature of the planet according to the house and the sign in which the receiver of power is. (4) If the planet receiving power is retrograde, it will send that power back to the planet that gave it. (5) The same applies if it is under the rays of the Sun within $15^{\circ}$.

10. (1) The scholars of India also said that one must always observe the 28 lunar mansions in any revolution of the year, at the time of the conjunction or opposition of the luminaries preceding the entrance of the Sun into the point where the day is equal to the night; and you must do this in the same manner in any month. (2) You always need to put as the root the conjunction or opposition of the luminaries that preceded the beginning of the revolution of the year in which the upper <planets> conjoined, because whatever is signified by this is general or universal. (3) The revolution of the year in which took place the conjunction of the 20 years signifies particular things, also the revolution of each year signifies the particular of the particular. (4) Moreover, the revolutions of the months signify the particulars of the particulars of the single things themselves.

11. (1) They also said that one must take into account which <planet> rules the revolution of the year, for it is the lord of the sign of the profection, or the lord of the end of the direction from the place of the great conjunction, or the lord of the revolution of the year either by aspect or by direction. (2) If, I say, Saturn, or Venus, or Mercury, or the Moon, is the lord, the year will be rainy, with plenty of rain, even more so if this lord is in a watery sign, or in a sign signifying water, like Aquarius and the end of Capricorn, for there it sheds water earlier and later, or Leo, where there is the shape of a ship. (3) If you want to know whether it will rain at the beginning or at the end of the year, observe the position of Venus at the moment of the entrance of the Sun in Libra. (4) If, I say, <Venus is > under the rays of the Sun and occidental, the rain will increase in the first half of the year and will decrease in the second half. (5) If Venus is seen and oriental <of the Sun>, the rain will be moderate in the first half of the year and the opposite in the second.

12. (1) Always pay attention to the 12 keys of the Moon. (2) The first is the moment of the conjunction of the Sun and Moon; the second is when the distance from the Sun is $12^{\circ}$; the third <is when the distance from the Sun is> $45^{\circ}$; the fourth, $90^{\circ}$; the fifth, $135^{\circ}$; the sixth, $168^{\circ}$; the seventh, $180^{\circ}$; the eighth, $192^{\circ}$; the ninth, $225^{\circ}$; the tenth, $270^{\circ}$; the eleventh, $315^{\circ}$; the twelfth, $348^{\circ}$.

13. (1) There are six lunar mansions signifying humidity, as follows: 4. al-dabarān; 12. al-șarfa; 16. al-zubānā; 17. al-iklī; 22. sa'd al-dhäbih̆; 27. al-fargh al-mu'akhkhar. (2) There are six dry mansions: 2. al-butayn, 6. al-han'a, 9. al-țarf, 18. al-kalabe, 25. sa'd al-akhbiya, 26 al-fargh al-awwal. (3) The other mansions are temperate or moderate. 
(4) You will be able to know the mansions in this manner: Take into consideration in which mansion the Moon is seen in the month under consideration and always subtract 9 equal degrees at this time from the position of the Sun and the Moon and likewise from the position of the other planets, so as to know the disposition or figure of the heavens of stars, and you need to begin from al-nath, that is alsaris, that is the ram's horns.

14. (1) All the Ancients and those who follow them agree that a planet conjoins another planet or aspects it in any aspect as long as it moves towards its aspect. (2) But in this point the scholars of the stars disagree, for some of them say that this will be so when there are less than $6^{\circ}$ between them. (3) Others said that this is according to the number of degrees of the spark of the planets. (4) For the spark of Saturn and Jupiter is $9^{\circ}$, Mars $8^{\circ}$, and Venus and Mercury $7^{\circ}$. (5) Others also said that the aspect is completed if, in the case of sextile, it is $60^{\circ}$ ahead of or behind and arrives at this number. (6) A lower planet that gives its power to an upper planet is still in the domain in which it was at the beginning, or before. (7) For it may happen that an aspect is completed and that an upper < planet $>$ moves towards another upper <planet> close to it, if it is direct <in its motion>. (8) If it is retrograde, it sometimes happens that a ray or aspect is completed in the domain in which it was not before. (9) This also happens to planets when the upper one is quick in its course and the lower one is slow. (10) Moreover, the truth of this is that the aspect must be weakened when the inferior <planet> begins to be under the spark of the upper <planet>, in conjunction and not in aspect. (11) And do not count the light or the spark with the beginning of the spark but the body with the body, the number with the number of the spark or light of the upper planet, and when it reaches the spark exactly at the number of $60^{\circ}$, it is in sextile ahead of or behind, and at the number of $90^{\circ}$ it is in quartile, and at the number of $120^{\circ}$ it is in trine, and at the number of $180^{\circ}$ it is in opposition. (12) Then the power of the aspect is the greatest, for then it shows its effect.

15. (1) Māshāallāh says: if the receiver of power is in a mobile sign, it will nearly give the number of its days. (2) The rule is that the mobile signs signify quickness, the fixed <signify> permanence, and the common <signify> moderateness. (3) The root about rain of all the aforesaid <elements> is that the houses of the luminaries are opposite Saturn's houses. (4) When at the moment of their conjunction or opposition they are with Saturn or form an aspect with it, they signify obscurity of the sky and heavy rain. (5) Combine the disposition of the mansions of the Moon with the aforesaid <elements>. (6) Jupiter with Mercury signifies winds, as does Venus in conjunction with Mars when separating <from conjunction> or under its ray or spark. (7) Pay attention if Mars is occidental <of the Sun> or in the watery signs, because this signifies rains, great lightning and thunder. (8) Likewise observe the Moon at the time of conjunction; if, I say, the Moon then, or in the 
Shlomo Sela, Carlos Steel, C. Philipp E. Nothaft, David Juste \& Charles Burnett

following quarter <of the month>, or when in opposition < to the Sun> conjoins a planet or forms an aspect with it, except for the Sun, this signifies clear sky until the next quarter <of the month>. (9) You must also observe the cardines in the place under consideration. For if the significator of rain is in any of the cardines of that place, the power of the rain will manifest itself there. (10) If it is in the intermediate <horoscopic> places, between them, I say, and the ascendant, in the binding of an aspect, there will be moderate rain, and if in the cadent $<$ horoscopic places>, there will not be <rain>.

16. (1) The scholars of Persia said: when Venus, the Moon and Mercury are in the humid lunar mansions, this signifies heavy rain, when the revolution of the year $<$ takes place in the humid lunar mansions it> signifies a rainy year, in the day of their conjunction or when it reaches an aspect in one degree, then there will rain, and even more so if the Moon is in one of its 12 keys, as I explained above.

17. (1) I will reconsider now the statement of Ptolemy, the wise, who said that the power of a planet is always manifested according to its nature when it is in the line of the orb of the signs and <when> it is direct <in its motion>. (2) If it is northern its power will increase, and if it is southern its power decreases. (3) If it is in the apogee, it will not manifest its power, or only moderately. (4) If it is opposite its apogee, then it will manifest its power greatly. But the scholars of India said the contrary. (5) I myself say that either statement is true, because every corporeal thing, like rain, cold and heat, is in its essence according to Ptolemy's statement, but in spiritual things, like exaltation, power, victory and dignity, it will be according to the statement of the scholars of India.

18. (1) I will now give you a common and general rule to know the essence of cold, heat, humidity and dryness. (2) Take always into consideration whether Saturn and Jupiter are in the figures of the uppermost circle, for Saturn signifies time in its entirety and Jupiter the year. (3) Examine, I say, the moment of the entrance of the Sun in the head of the mobile signs and observe whether the two upper $<$ planets> are in hot signs, because then this quarter of the year will be hot; and if in cold <signs $>$, <then this quarter of the year> will be cold; and if in humid <signs>, $<$ then this quarter of the year $>$ will be humid; and if they are in different places, as when one is in a hot sign and the other in a cold <sign>, this quarter will be temperate, and the same applies to humidity and dryness. (4) What I have just said is one testimony. (5) The second testimony is when the lord of the year is mixed with the upper <planets>, then you will judge by two testimonies. (6) If their places and nature are diverse, find out which of them has more power. (7) For if one of the upper < planets> is oriental <of the Sun>, <its> power is greater than if it were occidental <of the Sun>, and the opposite applies to the inferior planets. (8) The science of the lord of year consists in knowing the planet that has the greatest power in the five places of dignities at the beginning of the revolution of the year. 
19. (1) Māshāallāh said that one needs to associate the lord of the year with the planet that is in one of the cardines of the ascendant sign at the beginning of the year, and you must do the same thing <at the beginning> of every month, and in the first quarter, in the middle of the month, and in the second quarter <of the month>. (2) Here again, the days of the keys of the Moon are to be taken into consideration.

20. (1) Moreover, Abū Ma'shar said: the great key of rain is when Saturn conjoins the Sun at the moment of the conjunction or opposition <of the luminaries>, or when it is in any aspect to it, at the moment of keys of the Moon, because then it signifies heavy rain for many days. (2) The small key is the conjunction of one planet, in its body or by aspect, with a planet that is the lord of the house of its detriment or destruction, as if Mercury conjoins Jupiter, for this signifies humidity with a strong wind; likewise, Venus with Mars <signifies> humidity with lightning and thunder; the Moon with Saturn signifies a strong frost and snow in the winter. (3) Abū Ma'shar also said that he has tested for many years that when three planets conjoin in a watery sign, it signifies humidity.

21. (1) Kanakah, the Indian also said: if the sign of the conjunction or the opposition <of the luminaries> is one of the watery signs, this signifies rain, all the more so if the lord of the year aspects the place of the conjunction, and the same applies to the opposition. (2) If the lord of the year is in opposition to the conjunction of the sign, then the signification is stronger. (3) If the place of the conjunction or opposition is in one of the cardines of the ascendant sign, then the matter will be much stronger. (4) There will be rain when the Moon in its variable motion reaches the degree of the ascendant sign, and this has been tested. (5) The retrogradation of a planet when it is northern signifies humidity, even more so if this takes place in one of the watery signs and the Moon at the moment of conjunction or opposition gives power to the lord of the house of the conjunction or opposition or to that < planet > that has a dignity in the aforementioned place. (6) This signifies rain and the time of the event will be according to the number of degrees between the Moon and the ray of the planet, by conjunction or aspect, that is, according to the complement of the number. (7) For if there are three degrees between them, there will rain after three days from the retrogradation of the planet until the time of its opposition to the Sun. (8) If this is about the upper <planets>, it signifies humidity according to the signification from the time of its opposition to the Sun up to its second station. (9) The same applies to the inferior planets by its method, whereby it is common to from the beginning of the first station up to the opposition to the Sun or up to the opposition to the apogee of the epicycle, but it does not apply from this place up to the second station. (10) As a general rule rain is more signified by the time when the Moon separates from the conjunction or opposition to the Sun and gives power to a retrograde planet than when it gives 
Shlomo Sela, Carlos Steel, C. Philipp E. Nothaft, David Juste \& Charles Burnett

power to a direct <planet>. (11) But if the planet is in the second station, it signifies clear or serene weather up to the quarter when it is close to the opposition to its place.

22. (1) Sahl, the Jew, also said: you must take account, for the day under consideration, of the lot of weather, which you will know in this way. (2) You need to measure, for the day under consideration, the longitude between the place of the Sun and that of Saturn, and cast this number from the place of the Moon in the morning, at sunrise, and look whether this lot falls in one of Saturn's houses, because this signifies obscurity of the sky if Saturn aspects it and if it is in any of the lunar mansions signifying rain. (3) If the Moon falls in one of the houses of Jupiter or Mercury, this signifies winds, and this is even more so if the lord of the lot is in a sign signifying wind. (4) If it is in the houses of Venus, it signifies humidity, and this is even more so if it is in any of the lunar mansions signifying rain. (5) If it is in the houses of Mars, it signifies clear and serene weather unless this lot is in Scorpio and Mars is in a watery sign, because then the sky will not be completely serene. (6) If it is in the house of the Sun, the sky will be serene, and if in the house of the Moon, then it signifies humidity. (7) All this is true if the lord of the lot aspects this lot.

23. (1) Māshāallāh puts forward a general opinion, saying: take into consideration in the revolution of the year and observe the conjunction or opposition that took place in its beginning. (2) If the Moon is in conjunction with an unfortunate <planet> and similarly the degree of the conjunction or opposition either by conjunction or by aspect, and they are in the cardines of the ascendant sign, this signifies an unfortunate year as a result of diseases and death according to the nature of the unfortunate <planet>. (3) For Mars signifies heat and wars, all the more so if it is in a sign of human shape, but the Moon signifies any man in general. (4) If the Moon is with Saturn, this signifies serious and chronic diseases, particularly if Saturn is in an earthy sign. (5) If the Moon in the revolution of the year is in a cadent place and gives power to Jupiter or Venus, while these are not in cadent places, this signifies that many people will pass from affliction to liberty, and the contrary applies if the Moon is in a fortunate place and gives power to a falling planet, all the more so if the planet is unfortunate. (6) Know that the place of Mars signifies the places of wars.

24. (1) Abū Ma'shar said: you must always pay attention to the sign of the profection at the beginning of the great conjunction in the triplicity, and likewise at the beginning of the conjunction of the upper <planets > in 20 years. (2) Direct the place of the first conjunction by equal degrees and similarly by the ascension degrees of the place under consideration. (3) In the year in which it reaches exactly the place of Mars or the degree of its first place, or its conjunction, then they signify wars. (4) One must proceed in the same way in the judgement of the nature 
of any planet. (5) In any year in which Saturn is in quartile with Jupiter, and they are in the cardines of the first conjunction, it signifies quarrel of kings, and if Mars is there, investigate when new wars will break out.

25. (1) Know that there is a disagreement among the Ancients about the fiery signs. (2) For all say that the signs of the conjunctions are in charge of the eastern side, but Ptolemy says that their signification is on the northern side. (3) All the Ancients and also Ptolemy agree that the airy signs signify the occident. (4) All the Ancients say that the earthy <signs> are southern and the watery <signs> are northern. (5) Ptolemy agrees that the earthy signs are southern but he says that the fiery are northern.

26. (1) Abū Ma shar also says that he has tested many times that when a year signifies wars this is because Mars enters under the burning of the Sun, which are 6 degrees, or <because > Jupiter has a dignity in the ascendant sign at the moment of the conjunction or opposition that preceded the revolution. (2) In any year in which a planet returns to its place at the beginning of the year of a great conjunction, then it is linked with its ray and according to its power, something will be renewed in this year in accordance with the nature of the planet. (3) If the planet is a benefic and is the lord of the 6th, 8th or 12th <horoscopic> place according to the ascendant at the moment of the conjunction or opposition that preceded the revolution of the year, it will reduce its benefic effect. (4) If it is an unfortunate <planet>, this will augment <and causes pain over pain. (5) If a fortunate $<$ planet $>$ is in one of the cardines of the city under consideration, then it will be better, but if it is an unfortunate <planet>, it will then be worse. (6) If the sign of the city under consideration is not known to you, consider the great misfortune that will happen to that city. (7) You will be able to know its sign at the time of foundation of the city according to the method of reason.

[Colophon] This ends the Book on the judgments of the revolutions of the worldyears compiled by Ya'qub, the son of Isaac al-Kindī. This book was completed when Cancer was raising, and when the Moon was in conjunction with Jupiter in it, the third of September in the year of the Lord 1278, in Mechelen, translated from Hebrew into Latin by Henry Bate, at the request of Iohannes of Milana. 
Shlomo Sela, Carlos Steel, C. Philipp E. Nothaft, David Juste \& Charles Burnett

\title{
III. EDITION OF THE MIDDLE ENGLISH TEXT
}

\author{
III.1. Introduction \\ (C. Philipp E. Nothaft)
}

MS L = London, Royal College of Physicians, 384 is an anthology of astrological and astronomical texts, most of them translated from Latin into Middle English. Its 112 folios were all written by a single scribe, whose English secretarial hand can be dated to the late fifteenth or early sixteenth century (and after 1481). ${ }^{226}$ The texts assembled in $L$ include, on fols. $83 \mathrm{v}-85 \mathrm{r}$, a free Middle English translation of select passages of the tripartite text in $V$. Brief extracts from this translation were published in 2003 by John North, who attempted to interpret the astronomical data contained in it without knowledge of the fuller Latin version. ${ }^{227}$

While there is no reason to doubt that the Middle English text was translated from a Latin exemplar, the translator took certain liberties with the text, usually

226 For a full description of $L$, see David Juste's second contribution to this article. On astrological and astrology-adjacent texts in Middle English, see GEORGE R. KEISER, A Manual of the Writings in Middle English 1050-1500 (series editor Albert E. HARTUNG), vol. X, XXV. Works of Science and Information, The Connecticut Academy of Arts and Sciences, New Haven (Conn.) 1998, p. 36113624, 3759-3785; JoHN D. NoRTH, Richard of Wallingford: An Edition of His Writings with Introductions, English Translation and Commentary, 3 vols., Clarendon Press, Oxford 1976, vol. I, p. 181-243; vol. II, p. 94-97; LinNe R. MOONEY, «A Middle English Verse Compendium of Astrological Medicine », Medical History, 28 (1984), p. 406-419; MooneY, The Kalendarium of John Somer, University of Georgia Press, Athens (Ga.) 1998, p. 195-203; IRMA TAAVITSAINEN, Middle English Lunaries: A Study of the Genre, Société Néophilologique, Helsinki 1988 (Mémoires de la Société Néophilologique de Helsinki, 47); LAUREL MEANS, «Electionary, Lunary, Destinary, and Questionary: Toward Defining Categories of Middle English Prognostic Material », Studies in Philology, 89 (1992), p. 367-403; MEANs, «Ffor as moche as yche man may not haue pe astrolabe: Popular Middle English Variations on the Computus », Speculum, 67 (1992), p. 595-623; MEANs, Medieval Lunar Astrology: A Collection of Representative Middle English Texts, Edwin Mellen Press, Lewiston (NY) 1992; LISTER M. MATHESON, Ann Shannon, "A Treatise on the Election of Times », in Lister M. MAtheson (ed.), Popular and Practical Science of Medieval England, Colleagues Press, East Lansing (Mich.) 1994, p. 23-59; HILARY CAREY, « Medieval Latin Astrology and the Cycles of Life: William English and English Medicine in Cambridge, Trinity College MS 0.5.26 », in Anna AKasoy, Charles BuRnett, Ronit Yoeli-Tlalim (eds.), Astro-Medicine: Astrology and Medicine, East and West, SISMEL Edizioni del Galluzzo, Florence 2008 (Micrologus' Library, 25), p. 33-74; CARRIE GRIFFIn, The Middle English Wise Book of Philosophy and Astronomy: A Parallel-Text Edition; Edited from London, British Library, MS Sloane 2453 with a Parallel Text from New York, Columbia University, MS Plimpton 260, Universitätsverlag Winter, Heidelberg 2013 (Middle English Texts, 47); Isabel de la Cruz Cabanillas, Irene Diego RodríGuez, « Astrological Medicine in Middle English: The Case of Pe Booke of Ypocras », in MARÍA JosÉ EsteVE RAMOS, José RAMÓN PRADO-PÉREZ (eds.), Textual Reception and Cultural Debate in Medieval English Studies, Cambridge Scholars Publishing, Newcastle upon Tyne 2018, p. 79-99.

227 These excerpts correspond to Part I, \$7.1:12-14,17-18, and \$3.2-3. See NoRTH « Winchester 1067 », p. 139-140. 
by omission, but also by inserting synonyms and additional phrases as a means of clarification. Most of the passages he translated stem from the second of the two texts attributed to al-Kindī (i.e., Part III), but the degree to which these passages have been rearranged is rather drastic. Having placed the statement in the colophon in $V$ at the beginning, the translator segued from $\$ 1$ of Part I into a collage of different sections in Part III, jumping from $\$ 17$ to $\S \S 10,12,13,21,4$, and 9 (in this order). After a brief visit to the first two paragraphs of Part II, he abruptly switched again to the astronomical §7 of Part I, joining to it parts of §3 and \$2 (again in this order). The closing section of his translation encompasses several more paragraphs from Part III $(\$ \S 15-16,18-20)$. It is also worth noting that his abridged rendering of Part I, $\$ 7$, features several numerical variants compared to $V$, which at the very least suggests that the translation was not made from this particular manuscript. Similarly, in his rendering of Part III, \$13:4, the translator probably worked with a Latin exemplar that read ad sciendum dispositionem Lune sive figuram celi stellati ('forto know the disposicion of the Mone, or els the figure of the sterred hewyne'). In $V$, the word Lune is missing, once again indicating that it was not the basis for this translation.

In the transcription below, paragraph breaks have been set in a way so as to facilitate comparison with the edition of the Latin text. The corresponding Latin passage is indicated in square brackets at the start of each paragraph. Words and phrases without a direct counterpart in the Latin text are underlined, whereas the numerical variants in $\S 7$ of Part I are marked by «[!]» . As is the norm in critical editions, conjectural additions or emendations appear in pointed brackets. The occasional flourishes that the scribe added to words ending on -on, -en, or -em have been treated as decorative, meaning that preference was given to coniunccion over coniunccione or coniunccioun, to uppon over uppone, men over mene, hem over heme, and so on. The loop added to the root signif- has been interpreted as signifi or signifis depending on grammatical context. Otherwise, no attempt has been made to standardize or alter the spelling encountered in $L$. 
Shlomo Sela, Carlos Steel, C. Philipp E. Nothaft, David Juste \& Charles Burnett

\section{III.2. Edition \\ (C. Philipp E. Nothaft)}

I have wryten these thingis of the boke of domes of revolucions of the yeris of the world, the whiche Iacob the sone of Ysaak Alkyndy compyled, of the booke that was translate out of Ebrewe in to Latyne be Henry Bate.

[I, §1.1:3-9] After that the planetis be more or gretter or nyer to the erthe, after that her strenght shall appere the more. If the planet be within the part that is more within the orbe of his ententrill, or els in the opposite of his augis, his strenght shalle appere uppon the Erthe the more than ${ }^{228}$ it shoulde do if it were nye to the auge of his cercle. And therefore there is no place habitabil in the sowth parte of the erth, bycause of strenght of hete of the Sonne, for the Sonne is grettest of all other sterris that be seyne. ${ }^{229}$ The orbe of the signes in the which the fix sterris ben is the 8 orbe fro the erth. And all his sterris ben devyded into 48 thingis of the which 21 ben toward the northe fro the orbe of the signe and 15 toward the southe and 12 in the greete orbe the which <is the> gyrdell of the orbe of signis. And eche of these 12 partes or els divisions is clepyd in the name of an ymago the which is nye to hym in that orbe. The Mone and the other 5 planetis ben in the mydlyne of the orbe of the signis sumtyme and sumtyme thai passen that lyne alitel aswell on the right side as ${ }^{230}$ on the lyft syde. Fforsothe the Sonne kepith alway the myddel lyne of the orbe.

[III, \$17] Ptholome saide that the strenght of the planet shal signifi after his nature when he is in the lyne of the orbe of the signes and he is direct. But forsoth, if he be septemtrionall, id est northly, his strenght shalbe the more, and if he be southe, his strenght shalbe the lesse. But if it be so that he be in auge, he shal not shew his strenght right muche. But forsoth, the wise men of Inde saide the contrarie of this. And trewly I sai that the word is trewe in eche of these. For eche bodely thinge, as is reyne or colde or hete, governeth and hathe hem self in his beynge after the worde of Ptholomee. But in gostly thingis of the sowle, as is exa<l>tacion, strenght, victorie and dignite, it shalbe after the worde of wise men of Inde.

[III, §10:1-2] The wise men of Ynde said that a man shall alway loke after the 28 mansions of the Mone in every revolucion of the yere in the houre of coniunccion or opposicion of the lightis the which precedith and got before the entringe of the Sonne into Aries. And do this also in every moneth. Thou owest alway to put fro the rote and ${ }^{231}$ the grownde the coniunccion, or els the opposicion, of the lightis

228 than] the

229 seyne] seynene

230 as] os

231 and] a.c. of 
goyng before and precedinge the bygynnynge of the revolucion of the yere in the which the hiest planetis ben coniunct togeder.

[III, \$10:2-11:2] Fforsothe, what so evyr be signified or betokenyd, be this is general or else comyne, and the revolucion of the yere in which the coniunccion fallith of 20 yere it signifis uppon the particulers. But forsothe, the revolucion of $\mathrm{sy}<\mathrm{n}>$ guler yeris signifis upon the particulis of the particuler yere. And, more ovyr, the revolucions of monethtis signifi upon the particuler ${ }^{232}$ of particulers of singuler yeris. They said also that it is to be considerd what planet gothe before and is lorde of the revolucion of the yere. For he is lorde of the signe of profeccion, or lorde of the terme of direccion fro the place of the grete coniunccion, or els lorde of the revolucion of the yere, or be aspect or be dyrection. And forsothe, if Saturne be lord, or Venus or Mercury or the Moone, it shalbe a reynye yere with muche multitude of reyne and it shalbe muche the strenght if the lorde be in a watry signe, or in a signe signifyinge upon the water, as is Aquarye and ${ }^{233}$ thende of Capricorne, ffor forsothe, that $<i s>$ the pourer ${ }^{234}$ or shedder of water bothe fyrst and last, id est before and behynde, or els the signe of Leo, where the fygure of a shippe is.

[III, §12:1] Also a man must take hede to the 12 keys of the Moone.

[III, §13:1, 4] And forsoth, there be 6 mansions of the Mone signifis moistnes, id est the 4, the 12, the 16 and 17 , the 22 and 27 . And thou maist also have knowinge of the mansions [84r] in this manner: consider in what mansion the Mone is seyne in every moneth. Let alway be lessid and dimynut or withdraw that tyme fro the place of the Sonne and of the Mone and fro the placis of other planetis with degres equal forto know the disposicion of the Mone, or els the figure of the sterred hewyne, and that owist to bygyne the nomber fro the hornys of Aries.

[III, §21:1-4] Benaka of Inde said: if ${ }^{235}$ the signe of coniunccion, or els of opposicion, be any watry signe, and the lorde of the yere aspect the place of coniunccion, or els opposicion, that signifis reyne. But if the lorde of the yere be in opposit of the signe of coniunccion, then shall the significac $<i>$ on be more stronge. And if the place of coniunccion, or els opposicion, be in any of the anguls of the signe ascendent, then shal thinge be more stronge. And there shalbe reyne when the Moone shall cum with his dyvers mewinge to the gree of the signe ascendent. And ${ }^{236}$ this is expert and prevyd.

[III, §21:5-7] The retrogradacion of a planet, when it is on the lefte ${ }^{237}$ and in any of the watery signis, it signifis humydites. And if the Moone be the hore of

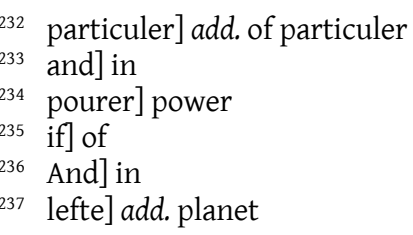


coniunccion or opposicion yewinge strenght to the lorde of the hous of coniunccion, or els of the opposicion, there beynge retrograde, or els to hem the which hath the dignite in the forsaid place, this forsoth signifis reyne and the tyme of hys commynge shalbe after the degrees the nombyr of ${ }^{238}$ whiche be bytweene the Mone and of the grees of the planet retrograde, be the coniunccion or els by aspect, that is to say after the fulfillinge of the nomber. And if there be betwene hem 3 degrees, there ${ }^{239}$ must nedys fall reyne within 3 dais.

[III, §4] Albu<masar> said: consider in every yere to the signe of perfeccion fro the signe of coniunccion and there ${ }^{240}$ after the degres that ben equal. And loke if there were any aspectinge signe of perfeccion in the bigynnyng of the coniunccion, or els in the hore of revolucion of the yere of the world, and gife to every gree 12 dais and an half and the sext part of a day. And putteth an example the signe of perfeccion fro the 8 gree of Libra to the 8 gree of Scorpion. And Iupiter is in the 12 degree of Libra and Saturne in the 2 gree and 30 minute in Scorpion. Then thou owist to know that every region and cite of the which Libra is the signe shalbe fortified and made stronge in this yere, and if Venus also be fortunate in the bygynnyng of the coniunccion and revolucion of the yere. And if Venus be infortunat it shalbe the contrarye. And if it be of goode beyng in the coniunccion and of evyll beynge in the revolucion, ${ }^{241}$ there shalbe a litell defaute fro goodenes. And if it be of evyl beynge in the coniunccion and of goode beynge in the revolucion, there shalbe a litell defaute of evyl. And because the longitude is of 4 degrees, there shall cum goode to every place of the which Libra is signe after 49 dais and parve, id est a litel more, and perfeccion to the place of Saturne <after $>10$ monethys. And there shalbe significacion of sekenes of the flux or of constipacion, id est cestifenes, and this shall signifie uppon bataile, for Saturne is in the hous of Mars and in his terme.

[III, §9] Yf a planet that is hyest and hath lordship uppon 5 placis of dignite, gife his strenght to the hyer ${ }^{242}$ planet in the tyme of coniunccion or opposicion of the lightis goynge before and precedinge the enteringe of the Sonne into Aries, then thou oewst to deme and shewe the strenght of the resaywinge after the kynde of the sterre. Also thou owist forto meddil the nature of the dignite with the nature of the planet after the hous and the signe in the which is the reseywer of strenght. And if the planet resaywinge the strenght be retrograde, it shall yeld that strenght to that planet the which that gafe it hem. And also it is in the same maner under the radiis of the Sonne into 15 degrees.

${ }^{238}$ of] add. degres the

239 there] that

240 there] the

${ }^{241}$ revolucion] add. and

${ }^{242}$ hyer] a.c. hyer; p.c. eyer 
[II, §1:1-2:7] Iacob the sonne of Ysaak Alkyndy said that the domes of all planetis dependend and hongen of the bygynnyng of coniunccion of 2 the hyest in signes of triplicites. And take to the figure of disposicion of the orbe of the signis. And know the signe of coniunccion. And knowe the degree ascendant in the hore of entringe of the Sonne into the signe or els the fygure of Aries. And this tyme is forto be withdrawen of the tabils the whiche be made after the way of probacion of 8 grees and 45 minutis and 30 secundis. And the Sonne entrethe the ymage of the signe of Aries bytwene the 22 day of Marche and 23. And then make ewyne the planet to that dai and that hore and withdrawe the forsaid moneth fro the place of the Moone and fro the place of other 5 planetis.

[II, \$2:12] The Sonne signifis uppon kyngis and princes that bene grete and other grete men. Saturne signifis olde men and tillors of the erthe. Iubiter domesmen and prestis. Mars knyghtis and mene of bataile and surgenes and surgery. Venus women. Mercury wisemen and scribes and merchandise. And the Mone is comparisoned and likend to the comune puple.

[I, §7.1:1-4,12-14] The bygynnyng of the yere of the grete coniunccion of 2 hiest planetis in erthy signis was in the yere of Arabim 459 in the 25 dai of the 4 moneth. But forsothe, after Cristen men it was in the 14 day of Marche in the yere of Cryst 1067. The longitud Wynconie fro the [84v] est is 19 degrees. The longitud of hem fro the myddis of the wor $<1>\mathrm{d}$ is $71^{243}$ degrees, the which be worth 4 horis and 44 minutis of an hore. Ascendent $\mathrm{in}^{244}$ the place of an evyne lyne the which is clepyd Arim was the 25 <degree> ascendant and 24 minutis of Aries. But the entringe of the Sonne into the hed of Aries in this place the which is in Wynconia was but 14 horis and 50 minutis after the mydde day in the 9 hore of the night. And the asc<endant> was 9 <degrees> and 43 minutis of Capricorne. And these bene the placis of the planetis: the Sonne 0.0.0; the Mone in Aquare 22.28; the hed of the Dragon in Virgo 11; Saturne in Virgo 14.55, the which was retrograde; Iubite $<r>$ in Virgo 2.1, retrograd<e> also; Mars in Aries 14.26; Venus 17.16[!] Ari<e>s; Mercury in Piscis 9.7. Also the place of coniunccion of hem after the table which y have made was 18.52[!] of Virgo.

[I, §7.1:17-22] And forsothe, also I founde of the coniunccion of theme in that day the which the Sonne was ioynid with hem by the space of 2 dais, that is to say, after the coniunccion of Saturne and Iubiter, in 0[!] degre and in 0[!] minute, and this was in 5 perfite dais of the moneth of Septembre in the yere of Our Lorde 1067 after the yere of Cristene men. And that is after the yere of Sarazens after the 23 day of the moneth of Zoall, the whiche is the 10 moneth in the nomber of her yeris $459^{245}$ fro the bygynnyng of the kyngdam of hem. And these ben the placis of other

$243 \quad 71] 11$

244 in] a.c. from

245 459] 1459 
Shlomo Sela, Carlos Steel, C. Philipp E. Nothaft, David Juste \& Charles Burnett

planetis in the day of that coniunccion: Mars 4.7.13; Venus 4.9.5; Mercury 6.12.25; Luna 3.10.12.4. The hed of the Dragon was nye to the place of hem in that of opposicion. Also the opposicion of the Sonne and the Moone precedinge the coniunccion of hem was the 26 day of August in the 8 degree, 59 minute, $22^{a}[!]$ of the signe of Piscis. And the place of the hede of the Dragon in the hore of the opposicion 5.6.50.48. And the latitude of the Moone was no more but 11 minutis and because of that ${ }^{246}$ that thinge that is signifyd is perfite. And the asc $<$ endant $>$ in Wynconia was 10[!] <degrees> and 7 minutis of Libra. But in the equinoxial lyne was the ascendent the 10[!] degree ${ }^{247}$ and the 5 minute of Capricorne.

[I, §3.2] The rote of the signes universal is after the $2 \mathrm{~h}<\mathrm{i}>\mathrm{est}$ planetis and the bigynnyng of the coniunccion of hem is in Aries. And after 20 yere thai shalbe commytte in Sagittare, and after other 20 yere in Leo, and thus it is done 12 or 13 tymes. And that shalbe in 240 yere or els in 260 yere. After this fyrie signes be changed into erthy signis after the way and the manner which thai had in the fyrie signes. And after this thai be changed into eyrie signes. And after that to waterie signes. And the coniunccion in triplicite is clepid the grete coniunccion. But forsoth, the coniunccion of 20 yere is clepid the lesse coniunccion.

[I, §3.3] And it is not possible to a man to ${ }^{248}$ fynde the minute of the coniunccion of hem, because of her slow mewinge. The placis, forsothe, of the planetis be fo $<\mathrm{u}>$ nden by instrumentis of prevyng, in the which secundis may not be designede, id est be rekoned. Wherefore the wise men of the domes of astrologis ben sustenid uppon the revolucion of the yere of the world and uppon the asc $<$ endant $>$ and placis of the lyne equall, or els of the myddis of the world, more over and uppon the ascendent of every place after his longitude and his latitude in the houre of coniunccion and opposicion of lightis to the revolucion of the yere and before the entringe of the Sonne into 4 meble signis and before the coniunccion of 2 of the hiest planetis. And this is the trewth.

[I, §3.4] And knowel that the signe of Ynde is Aquare and Leo is <the> signe of Cristen men and Scorpio with laid of Sarazens, because that in the terme of Venus was the coniunccion of the sect of Sarazens. Many also wise men loken after the coniunccion of Saturne and Mars, the which in all thingis is seene in 30 yere onys in the signe of Cancer.

[I, \$2.6:5] Saturne signifis uppon olde folke and uppon olde kyngdam and Iupiter signifis uppon new folke and uppon newe kyngdam.

[III, §15] Also Messahalla saith: if the resayver of the strenght be in a noble signe, he shall as it were gife his nomber of days. And this same is generall <that $>$

246 of that] that of

247 degree] dignee

248 to] s.l. 
the meble signis signifi hastin<g>es and fix signes signifi abyding and stedfastnes. And mene signes singifi meen. The rote of all thingis before said, that is to sai of reyne, is that the hous of lightis bene opposite to the hous of Saturne. But then when thai be with Saturne or els his aspectis in the hore of coniunccion or els opposicion, thai signifi darknes of eyre and muche reyne. And loke that thou meddell the disposicions of the mansions of the Mone with the same. Iubit<er>also with Mercury signifis windis. Venus with Mars, if Mars be occidentall or, els in wateri signes, signifis reyne and grete lightningis and thondres. Also take hede of the Moone in the hore of coniunccion and, forsoth, if the Mone be in the folowynge $4^{\mathrm{a}}$ or in the opposite coniunct, id est ioynd, to the planet, or els in his aspect, except that that is of the Sonne, then this shalbe taken clerenes of wedden into that next quarter folowynge. ${ }^{249}$ Thou owest also to knowe the angul in eche placis, for if the significator of reyne be in any angul in that place, there shall the strenght of reyne be shewid. And if it be in the housys interm<ed>ys, id est bytwene hem and ${ }^{250}$ the asc<endant>, the aspect shalbe in ligacion, id est in byndinge, and so there shall fall a litell reyne. And if it be in the fallinge, id est cadent, there shall non be.

[III, §16] The wise men of Persayne saide also [85r] that when Venus, Mercury and Luna bene in moist mansions of the Mone that signifis grete reyne where the revolucion of the yere shal signifi a reynye yere in the day of coniuncion of hem, or els when thai cum to aspect in $\underline{0}$ degre $<\mathrm{e}>$, thane shalbe reyne. And the reyne shalbe the more if the Mone be in any of the 12 kyyes after that that I have made pleyne and opyne byforne.

[III, §18] Now than I shall yewe the<e> a comen rule and a generall forto know the beynge, id est the kynde, of colde and hote and moistnes and drynes. Fforsoth thou shall alway consider to Saturne and Iubiter after that thai have them in the figur<i>s of the hyer cercle. For Saturne hath kynde forto signifi uppon the tyme of his totalite. And Iubiter hath forto signifi upon the yere. Thou shalt also consider to the hore and take hede of the entringe of the Sonne into the hedis of meble signis and loke if the 2 hiest planetis bene in the hote signis, for then the quarter shalbe in hete. And if it be in cold signis it shalbe in colde. And if it be in moist signis, it shalbe moist. And if it be in placis on like, as one in an hotte signe and another in a colde signe, that quarte shalbe temperate in the same moneth. Also it hath in moistnes and drynes. This than that I have said is o<ne> wittnes. The secunde witnes is when he is lorde of the yere comyxt and medlid with the hiest planetis. For then shall thou deme by 2 witnessis. But if the placis of hem and her beynge be divers, know well that the workynge of hem hath the more strenght.

249 folowynge] sewinge

250 and] in 
Shlomo Sela, Carlos Steel, C. Philipp E. Nothaft, David Juste \& Charles Burnett

Ffor if ${ }^{251}$ one ${ }^{252}$ of the hiest be oriental it is of more strenght than if it be occidental, but $^{253}$ in the lower planetis eche thinge hath hem evyne the contrarye. Butt forsothe, the knowinge of the lorde of the yere is fortobe knowen the planet the which hathe more strenght uppon the 5 placis of dignites in the bygynnyng of the revolucion of the yere.

[III, §19] Messahala also said that alway the lorde of the yere is forto be medlyd with the planet which shalbe in any of the co<r>ners or angullis of the signe asc<endant> in the bygynnyng of the yere. In the same manner also it is forto do in every ${ }^{254}$ moneth and in the first quarte. And in the myddis of the monethe. And in the 2 quarte. Yet forsothe is to consider the dais of the keys of the Mone.

[III, §20:1-2] Also evermore Albumysar said: the grete key of reyne is when Saturne is commyned with the Sonne in the hore of coniunction, or els opposicion, or els when he is in any of his aspectis in the houris of the keyes of the Moone, for then it shall signifi grete reyne duringe many days. A litell key is coniunccion of an other planet co<r>poral, or els be aspecte with the planet the which shalbe lorde of the hous. And if Mercury be ioyned with Iubiter for that signifis moistnes with grete winde. And also like Venus with Mars uppon moistnes with lightnyngis and thondringis. And the Mone with Saturne signifis grete frost and snowe in wynter.

Explicit liber iste.

$$
\begin{aligned}
& 251 \text { if] it } \\
& 252 \text { one] s.l. } \\
& 253 \text { but] be } \\
& 254 \text { every] a.c. the }
\end{aligned}
$$




\section{Bibliography}

Manuscripts

Cambridge, Fitzwilliam Museum, McClean 165

Cambridge, University Library, Kk.1.1

Cambridge, University Library, Mm.3.11

Erfurt, Universitäts- und Forschungsbibliothek, Dep. Erf. CA $4^{\circ} 364$

Erfurt, Universitäts- und Forschungsbibliothek, Dep. Erf. CA $4^{\circ} 381$

Florence, Biblioteca Nazionale Centrale, Conv. soppr. J.V.6

København, Det Kongelige Bibliotek, Gks $2772^{\circ}$

London, British Library, Arundel 377

London, Royal College of Physicians, 384

Escorial, Real Biblioteca del Monastario de San Lorenzo, 918/2

Oxford, Bodleian Library, Digby 40

Oxford, Bodleian Library, Savile 22

Paris, Bibliothèque nationale de France, lat. 16208

Parma, Biblioteca Palatina, 718-720

Tehran, Majlis-i Shūrā-Millī 6452

Vatican City, Biblioteca Apostlica Vaticana, lat. 3119

Vatican City, Biblioteca Apostolica Vaticana, Pal. lat. 1407

\section{Printed sources}

Abraham Bar Hiyya, Chapter 17 of Hešbon Mahalakhot ha-Kokhavim, in Shlomo Sela, "Chapter 17 of Hešbon Mahalakhot ha-Kokhavim by Abraham Bar Hiyya - The First Hebrew Catalog of Constellations, Fixed Stars and Lunar Mansions: Critical Edition, English Translation and Commentary », Suhayl, 15 (2017), p. 231-296, esp. 251-273.

Abū Ma'shar, The Great Introduction to Astrology, ed. and trans. Keiji Yamamoto, Charles Burnett, Brill, Leiden 2019 (Islamic Philosophy, Theology and Science, 106). 
Shlomo Sela, Carlos Steel, C. Philipp E. Nothaft, David Juste \& Charles Burnett

Abraham Ibn Ezra, De revolutionibus, trans. Henry Bate, in Abrahe Avenaris Iudei Astrologi peritissimi in re iudiciali opera: ab excellentissimo philosopho Petro de Abano post accuratam castigationem in Latinum traducta, Petrus Liechtenstein, Venice 1507.

- 'Iggeret ha-Shabbat, in The Sabbath Epistle of Rabbi Abraham Ibn Ezra: 'Iggeret haShabbat, ed. and trans. Mordechai S. Goodman, Ktav, Jerusalem 2009.

- De nativitatibus, ed. Sela: Liber Abraham Iudei de nativitatibus in Abraham Ibn Ezra Latinus on Nativities: A Parallel Latin-English Critical Edition of 'Liber Nativitatum' and 'Liber Abraham Iudei de Nativitatibus', ed. and trans. Shlomo Sela, Brill, Leiden 2019 (Études sur le judaïsme médiéval, 78), p. 250-351.

- Electiones, ed. Sela: Liber electionum in Abraham Ibn Ezra Latinus on Elections and Interrogations, A Parallel Hebrew English Critical Edition of 'Liber Electionum', 'Liber Interrogationum', and 'Tractatus Particulares', ed., trans., and annot. Shlomo Sela, (forthcoming).

- Interrogationes, ed. Sela: Liber interrogationum in Abraham Ibn Ezra Latinus on Elections and Interrogations, A Parallel Hebrew English Critical Edition of 'Liber Electionum', 'Liber Interrogationum', and 'Tractatus Particulares', ed., trans., and annot. Shlomo Sela, (forthcoming).

- Liber de rationibus tabularum, in El libro de los fundamentos de las Tablas astronómicas de R. Abraham Ibn 'Ezra, ed. José M. ${ }^{a}$ Millás Vallicrosa, CSIC, Madrid 1947 (Instituto Arias Montano, Ser. D, 2).

- Me'orot, ed. Sela: Sefer ha-Me'orot in Abraham Ibn Ezra on Elections, Interrogations and Medical Astrology, ed. and trans. Shlomo Sela, Brill, Leiden 2011 (Études sur le judaïsme médiéval, 50), p. 452-483.

- Mishpetei ha-Mazzalot, ed. Sela: Sefer Mishpetei ha-Mazzalot in Abraham Ibn Ezra's Introductions to Astrology, ed. and trans. Shlomo Sela, Brill, Leiden 2017 (Études sur le judaïsme médiéval, 69), p. 452-483.

- Moladot, ed. Sela: Sefer ha-Moladot in Abraham Ibn Ezra on Nativities and Continuous Horoscopy, ed. and trans. Shlomo Sela, Brill, Leiden 2013 (Études sur le judaïsme médiéval, 59), p. 84-203.

- Nativitates, ed. Sela: Liber nativitatum in Abraham Ibn Ezra Latinus on Nativities: A Parallel Latin-English Critical Edition of Liber 'Nativitatum' and 'Liber Abraham Iudei de Nativitatibus', ed. and trans. Shlomo Sela, Brill, Leiden 2019 (Études sur le judaïsme médiéval, 78), p. 80-159.

- 'Olam I, ed. Sela: first version of Sefer ha-'Olam, in Abraham Ibn Ezra: The Book of the World, ed. and trans. Shlomo Sela, Brill, Leiden 2010 (Études sur le judaïsme médiéval, 39), p. 52-97. 
- 'Olam II, ed. Sela: second version of Sefer ha-'Olam, in Abraham Ibn Ezra: The Book of the World, ed. and trans. Shlomo Sela, Brill, Leiden 2010 (Études sur le judaïsme médiéval, 39), p. 156-191.

- Reshit Hokhmah, ed. Sela: Sefer Reshit Hokhmah, in Abraham Ibn Ezra's Introductions to Astrology, ed. and trans. Shlomo Sela, Brill, Leiden 2017 (Études sur le judaïsme médiéval, 69), p. 48-271.

- Sefer Haibbur, in Sefer Ha'ibbur: A Treatise on the Calendar by Rabbi Abraham Ibn Ezra, ed. and trans. Mordechai S. Goodman, Ktav, Jerusalem 2011.

- She'elot I, ed. Sela: first version of Sefer ha-She' elot in Abraham Ibn Ezra on Elections, Interrogations and Medical Astrology, ed. and trans. Shlomo Sela, Brill, Leiden 2011 (Études sur le judaïsme médiéval, 50), p. 240-297.

- She elot II, ed. Sela: second version of Sefer ha-She'elot in Abraham Ibn Ezra on Elections, Interrogations and Medical Astrology, ed. and trans. Shlomo Sela, Brill, Leiden 2011 (Études sur le judaïsme médiéval, 50), p. 348-397.

- Téamim I, ed. Sela: first version of Sefer ha-Te'amim, in Abraham Ibn Ezra: The Book of Reasons, ed. and trans. Shlomo Sela, Brill, Leiden 2007 (Études sur le judaïsme médiéval, 35), p. 28-107.

- Te'amim II, ed. Sela: second version of Sefer ha-Te'amim, in Abraham Ibn Ezra: The Book of Reasons, ed. and trans. Shlomo Sela, Brill, Leiden 2007 (Études sur le judaïsme médiéval, 35), p. 182-257.

- Tequfah, ed. Sela: Sefer ha-Tequfah in Abraham Ibn Ezra on Nativities and Continuous Horoscopy, ed. and trans. Shlomo Sela, Brill, Leiden 2013 (Études sur le judaïsme médiéval, 59), p. 372-389.

Adelard of Bath, De opere astrolapsus, in Bruce George Dickey, « Adelard of Bath: An Examination Based on heretofore Unexamined Manuscripts ", Ph.D. Diss., University of Toronto 1982.

Epistle on Music of the Ikhwān al-Ṣafā', ed. Amnon Shiloah, Tel Aviv University, Tel Aviv 1978.

Epitome totius astrologiae, conscripta a Ioanne Hispalensi Hispano Astrologo celeberrimo, ante annos quadringentos, ac nunc primum in lucem edita. Cum praefatione Ioachimi Helleri Leucopetraei, contra Astrologiae adversarios, in officina Ioannis Montani et Ulrici Neuber, Nuremberg 1548.

Ezich Elkaurezmi, trans. Adelard of Bath, in Die astronomischen Tafeln des Muhammed ibn Mūsā al-Khwārizmī in der Bearbeitung des Maslama ibn Aḥmed al-Madjrīți und der latein. Übersetzung des Athelhard von Bath, ed. Heinrich Suter, A. F. Høst \& Søn, 
Shlomo Sela, Carlos Steel, C. Philipp E. Nothaft, David Juste \& Charles Burnett

København 1914 (Det Kongelige Danske Videnskabernes Selskab, Skrifter, 7th Ser., Historisk og filosofisk Afd., 3.1).

Al-Bīrūnī, The Chronology of Ancient Nations, trans. and ed. C. Edward Sachau, London 1879, (Oriental Translation Fund of Great Britain \& Ireland)

Henry Bate, Equatorium planetarum, in Opusculum Abrahe Iudei de nativitatibus cum exemplaribus figuris singulis domibus antepositis: Et magistralis compositio astrolabii Hanrici Bate, Erhardus Ratdolt, Venice 1485.

- Speculum divinorum et quorundam naturalium (pt. XX-XXIII), ed. Carlos Steel, Guy Guldentops, Leuven University Press, Leuven 1996 (Ancient and Medieval Philosophy, De Wulf-Mansion Centre, Series 1, 23).

Hermann of Carinthia, De essentiis, ed. Charles Burnett, Brill, Leiden 1982 (Studien und Texte zur Geistesgeschichte des Mittelalters, 15).

Ibn al-Muthannā, Commentary on the Astronomical Tables of al-Khwārizmī, trans. Abraham Ibn Ezra, in Ibn al-Muthannâ's Commentary on the Astronomical Tables of alKhârizmî: Two Hebrew Versions, Edited and Translated with an Astronomical Commentary, trans. Bernard R. Goldstein, Yale University Press, New Haven (Conn.) 1967.

Petrus Alfonsi, Dialogus, vol. I, ed. Carmen Cardelle de Hartmann, Darko Senekovic, Thomas Ziegler, and Peter Stotz, SISMEL Edizioni del Galluzzo, Florence 2018.

Petrus de Alliaco [Pierre d'Ailly], De concordantia discordantium astronomorum, ed. Johannes de Westfalia, Leuven 1477/83.

Raymond de Marseille, Liber cursuum planetarum, in Opera omnia, vol. I, ed. MarieThérèse d'Alverny, Charles Burnett, Emmanuel Poulle, CNRS Éditions, Paris 2009 (Sources d'Histoire Médiévale, 40).

Theorica planetarum Gerardi, ed. Francis J. Carmody, Berkeley (Ca.) 1942.

The Toledan Tables, ed. Fritz S. Pedersen, 4 vol., C. A. Reitzel, København 2002 (Det Kongelige Danske Videnskabernes Selskab, Historisk-filosofiske Skrifter, 24.1-4).

Modern authors (after 1789)

Bos, Gerrit, Charles Burnett, Scientific Weather Forecasting in the Middle Ages: The Writings of al-Kindī, Kegan Paul International, London 2000.

Burnett, Charles, « Abd al-Masīh of Winchester », in Lodi Nauta, Arjo Vanderjagt (eds.), Between Demonstration and Imagination: Essays in the History of Science and Philosophy Presented to John D. North, Brill, Leiden 1999 (Brill's Studies in Intellectual History, 96), p. 159-169. 
- «Latin Alphanumerical Notation, and Annotation in Italian, in the Twelfth Century: MS London, British Library, Harley, 5402 », in Menso Folkerts, Richard Lorch (eds.), Sic itur ad astra: Studien zur Geschichte der Mathematik und Naturwissenschaften; Festschrift für den Arabisten Paul Kunitzsch zum 70. Geburtstag, Harrassowitz, Wiesbaden 2000, p. 77-90.

- «Indian Numerals in the Mediterranean Basin in the Twelfth Century, with Special Reference to the 'Eastern Forms' ", in Yvonne Dold-Samplonius, Joseph W. Dauben, Menso Folkerts, Benno van Dalen (eds.), From China to Paris: 2000 Years Transmission of Mathematical Ideas, Franz Steiner Verlag, Stuttgart 2002 (Boethius, 46), p. 237-288.

- «The Transmission of Arabic Astronomy via Antioch and Pisa in the Second Quarter of the Twelfth Century », in Jan P. Hogendijk, Abdelhamid I. Sabra (eds.), The Enterprise of Science in Islam: New Perspectives, MIT Press, Cambridge (Mass.) 2003, p. 23-51.

- «Weather Forecasting, Lunar Mansions and a Disputed Attribution: The Tractatus pluviarum et aeris mutationis and Epitome totius astrologiae of 'Iohannes Hispalensis' », in Anna Akasoy, Wim Raven (eds.), Islamic Thought in the Middle Ages: Studies in Text, Transmission and Translation, in Honour of Hans Daiber, Brill, Leiden 2008 (Islamic Philosophy, Theology and Science: Texts and Studies, 75), p. 219-265.

Carey, Hilary, « Medieval Latin Astrology and the Cycles of Life: William English and English Medicine in Cambridge, Trinity College MS 0.5.26 », in Anna Akasoy, Charles Burnett, Ronit Yoeli-Tlalim (eds.), Astro-Medicine: Astrology and Medicine, East and West, SISMEL Edizioni del Galluzzo, Florence 2008 (Micrologus' Library, 25), p. 33-74.

Chabás, José, Bernard R. Goldstein, A Survey of European Astronomical Tables in the Late Middle Ages, Brill, Leiden 2012 (Time, Astronomy, and Calendars: Texts and Studies, 2).

de la Cruz Cabanillas, Isabel, Irene Diego Rodríguez, « Astrological Medicine in Middle English: The Case of Pe Booke of Ypocras », in María José Esteve Ramos, José Ramón Prado-Pérez (eds.), Textual Reception and Cultural Debate in Medieval English Studies, Cambridge Scholars Publishing, Newcastle upon Tyne 2018, p. 79-99.

Eagleton, Catherine, Monks, Manuscripts and Sundials: The Navicula in Medieval England, Brill, Leiden 2010 (History of Science and Medicine Library, 13; Medieval and Early Modern Science, 11).

Gautier Dalché, Patrick, "La Terre dans le cosmos», in Id. (ed.), La Terre: connaissance, représentations, mesure au Moyen Âge, Brepols, Turnhout 2013 (L'Atelier du Médiéviste, 13), p. 161-257. 
Shlomo Sela, Carlos Steel, C. Philipp E. Nothaft, David Juste \& Charles Burnett

Goldstein, Bernard R., The Astronomical Tables of Levi ben Gerson, Archon Books, Hamden (Conn.) 1974 (Transactions of The Connecticut Academy of Arts and Sciences, 45).

Griffin, Carrie, The Middle English Wise Book of Philosophy and Astronomy: A ParallelText Edition; Edited from London, British Library, MS Sloane 2453 with a Parallel Text from New York, Columbia University, MS Plimpton 260, Universitätsverlag Winter, Heidelberg 2013 (Middle English Texts, 47).

Guesmi, Chedli, Julio Samsó, Astrometeorología en al-Andalus y el Magrib entre los siglos VIII y XV, Brepols, Turnhout 2018.

Keiser, George R., A Manual of the Writings in Middle English 1050-1500 (series editor Albert E. Hartung), vol. X, XXV. Works of Science and Information, The Connecticut Academy of Arts and Sciences, New Haven (Conn.) 1998.

Ker, Neil R., Medieval Manuscripts in British Libraries, vol. I, London, Clarendon Press, Oxford 1969.

King, David A., Julio Samsó, « Astronomical Handbooks and Tables from the Islamic World (750-1900): An Interim Report », Suhayl, 2 (2001), p. 9-105.

Laguarda Trias, Rolando A., La ciencia española en el descrubrimiento de America (las tablas de coordenadas geográficas compiladas en la España medieval), Casa-Museo de Colon y Seminario Americanista de la Universidad de Valladolid, Valladolid 1990 (Cuadernos Colombinos, 16).

Matheson, Lister M., Ann Shannon, «A Treatise on the Election of Times », in Lister M. Matheson (ed.), Popular and Practical Science of Medieval England, Colleagues Press, East Lansing (Mich.) 1994, p. 23-59.

Means, Laurel, « Electionary, Lunary, Destinary, and Questionary: Toward Defining Categories of Middle English Prognostic Material », Studies in Philology, 89 (1992), p. 367-403.

- «Ffor as moche as yche man may not haue Pe astrolabe: Popular Middle English Variations on the Computus », Speculum, 67 (1992), p. 595-623.

- Medieval Lunar Astrology: A Collection of Representative Middle English Texts, Edwin Mellen Press, Lewiston (NY) 1992.

Mercier, Raymond, "Astronomical Tables in the Twelfth Century ", in Charles Burnett (ed.), Adelard of Bath: An English Scientist and Arabist of the Early Twelfth Century, The Warburg Institute, London 1987 (Warburg Institute Surveys and Texts, 14), p. 87-118. 
- «The Lost Zij of al-Ṣūfī in the Twelfth-Century Tables for London and Pisa », in Id., Studies on the Transmission of Medieval Mathematical Astronomy, Ashgate, Aldershot 2004 (Variorum Collected Studies Series, 787), ch. 8.

Mooney, Linne R., "A Middle English Verse Compendium of Astrological Medicine », Medical History, 28 (1984), p. 406-419.

- The Kalendarium of John Somer, University of Georgia Press, Athens (Ga.) 1998.

Muñoz Jiménez, Rafael, "Una maqāla astrológica de al-Kindī », Boletín de la Asociacion Española de Orientalistas, 15 (1979), p. 127-139.

Neugebauer, Otto, The Astronomical Tables of Al-Khwärizmī: Translation with Commentaries of the Latin Version ed. by H. Suter, Supplemented by Corpus Christi College MS 283, Munksgaard, København 1962 (Det Kongelige Danske Videnskabernes Selskab, Historisk-filosofiske Skrifter, 4.2).

North, John D., Richard of Wallingford: An Edition of His Writings with Introductions, English Translation and Commentary, 3 vol., Clarendon Press, Oxford 1976.

- « The Longitudes of Winchester », Cahiers de l'Institut du Moyen-Âge Grec et Latin, 73 (2002), p. 13-20.

- «Winchester $1067 »$, Centaurus, 45 (2003), p. 130-141.

Nothaft, C. Philipp E., Walcher of Malvern: 'De lunationibus' and 'De Dracone'; Study, Edition, Translation, and Commentary, Brepols, Turnhout 2017 (De Diversis Artibus, 101 [N.S. 64]).

- « Henry Bate's Tabule Machlinenses: The Earliest Astronomical Tables by a Latin Author », Annals of Science, 75 (2018), p. 275-303.

- «Ptolemaic Orbs in Twelfth-Century England: A Study and Edition of the Anonymous Liber de motibus planetarum », Mediterranea: International Journal for the Transfer of Knowledge, 3 (2018), p. 145-210.

- Scandalous Error: Calendar Reform and Calendrical Astronomy in Medieval Europe, Oxford University Press, Oxford 2018.

Pedersen, Fritz S., « Astronomical Tables for Pisa in Ms. København K.B., GkS 277, Fol », Renassanceforum, 3 (2007), p. 1-16.

Pingree, David, «Indian Astronomy in Medieval Spain », in Josep Casulleras, Julio Samsó (eds.), From Baghdad to Barcelona: Studies in the Islamic Exact Sciences in Honour of Prof. Juan Vernet, vol. I, Instituto « Millás Vallicrosa » de Historia de la Ciencia Arabe, Barcelona 1996, p. 39-48.

Saliba, George, «Critiques of Ptolemaic Astronomy in Islamic Spain », Al-Qanțara, 20 (1999), p. 3-25. 
Shlomo Sela, Carlos Steel, C. Philipp E. Nothaft, David Juste \& Charles Burnett

Samsó, Julio, "'Dixit Abraham Iudeus': algunas observaciones sobre los textos astronómicos latinos de Abraham Ibn 'Ezra », Iberia Judaica, 4 (2012), p. 171-200.

Sela, Shlomo, Abraham Ibn Ezra and the Rise of Medieval Hebrew Science, Brill, Leiden 2003 (Brill's Series in Jewish Studies, 32).

- Abraham Ibn Ezra: The Book of Reasons. A Parallel Hebrew-English Critical Edition of the Two Versions of the Text, Brill, Leiden 2007 (Études sur le judaïsme médiéval, 35).

- Abraham Ibn Ezra: The Book of the World, A Parallel Hebrew-English Critical Edition of the Two Versions of the Text, Brill, Leiden 2010 (Études sur le judaïsme médiéval, 39).

- Abraham Ibn Ezra on Elections, Interrogations, and Medical Astrology. A Parallel Hebrew-English Critical Edition of the 'Book of Elections' (3 Versions), the 'Book of Interrogations' (3 Versions), and the 'Book of the Luminaries', Brill, Leiden 2011 (Études sur le judaïsme médiéval, 50).

- Abraham Ibn Ezra on Nativities and Continuous Horoscopy. A Parallel Hebrew-English Critical Edition of the 'Book of Nativities' and the 'Book of Revolution', Brill, Leiden 2013 (Études sur le judaïsme médiéval, 59).

- Abraham ibn Ezra's Introductions to Astrology. A Parallel Hebrew-English Critical Edition of the Book of the Beginning of Wisdom and the Book of the Judgments of the Zodiacal Signs, Brill, Leiden 2017 (Études sur le judaïsme médiéval, 69).

- « The Ibn Ezra-Henry Bate Astrological Connection and the Three Abrahams », Mediterranea, 2 (2017), p. 163-186.

- Abraham Ibn Ezra Latinus on Nativities: A Parallel Latin-English Critical Edition of 'Liber Nativitatum' and 'Liber Abraham Iudei de Nativitatibus', Brill, Leiden 2019 (Études sur le judaïsme médiéval, 78).

- Abraham Ibn Ezra Latinus on Elections and Interrogations. A Parallel Latin-English Critical Edition of 'Liber Electionun', 'Liber Interrogationum', and 'Tractatus Particulares', Brill, Leiden 2020 (Études sur le judaïsme médiéval, 83).

- «The Impact of Hagin Le Juif's French Translations on Subsequent Latin Translations of Abraham Ibn Ezra's Astrological Writings ", Jewish Quarterly Review (forthcoming).

Sela, Shlomo, Gad Freudenthal, "Abraham Ibn Ezra's Scholarly Writings: A Chronological Listing », Aleph, 6 (2006), p. 13-55.

Schuba, Ludwig, Die Quadriviums-Handschriften der Codices Palatini Latini in der Vatikanischen Bibliothek, Reichert, Wiesbaden 1992 (Kataloge der Universitätsbibliothek Heidelberg, 2). 
Steel, Carlos, Steven Vanden Broecke, David Juste, Shlomo Sela, The Astrological Autobiography of a Medieval Philosopher: Henry Bate's 'Nativitas' (1280-1281), Leuven University Press, Leuven 2018 (Ancient and Medieval Philosophy. Series 1, 17).

Steel, Carlos, «Henry Bate's Translation of Ibn Ezra's treatise The Book of the World. A Critical Edition», in Marienza Benedetto (ed.), Le stelle, i regni, le credenze e le masse. L'astrologia politica nel Mediterraneo fra Medioevo e Rinascimento, Pagina-Brepols, Bari - Turnhout (forthcoming).

Swerdlow, Noel M., «Ptolemy's Harmonics and the 'Tones of the Universe' in the Canobic Inscription », in Charles Burnett, Jan P. Hogendijk, Kim Plofker, Michio Yano (eds.), Studies in the History of the Exact Sciences in Honour of David Pingree, Brill, Leiden 2004 (Islamic Philosophy, Theology and Science: Texts and Studies, 54), p. 137-180.

Taavitsainen, Irma, Middle English Lunaries: A Study of the Genre, Société Néophilologique, Helsinki 1988 (Mémoires de la Société Néophilologique de Helsinki, 47).

Toomer, G. J., « The Solar Theory of az-Zarqāl: A History of Errors », Centaurus 14 (1969), p. 306-336. 